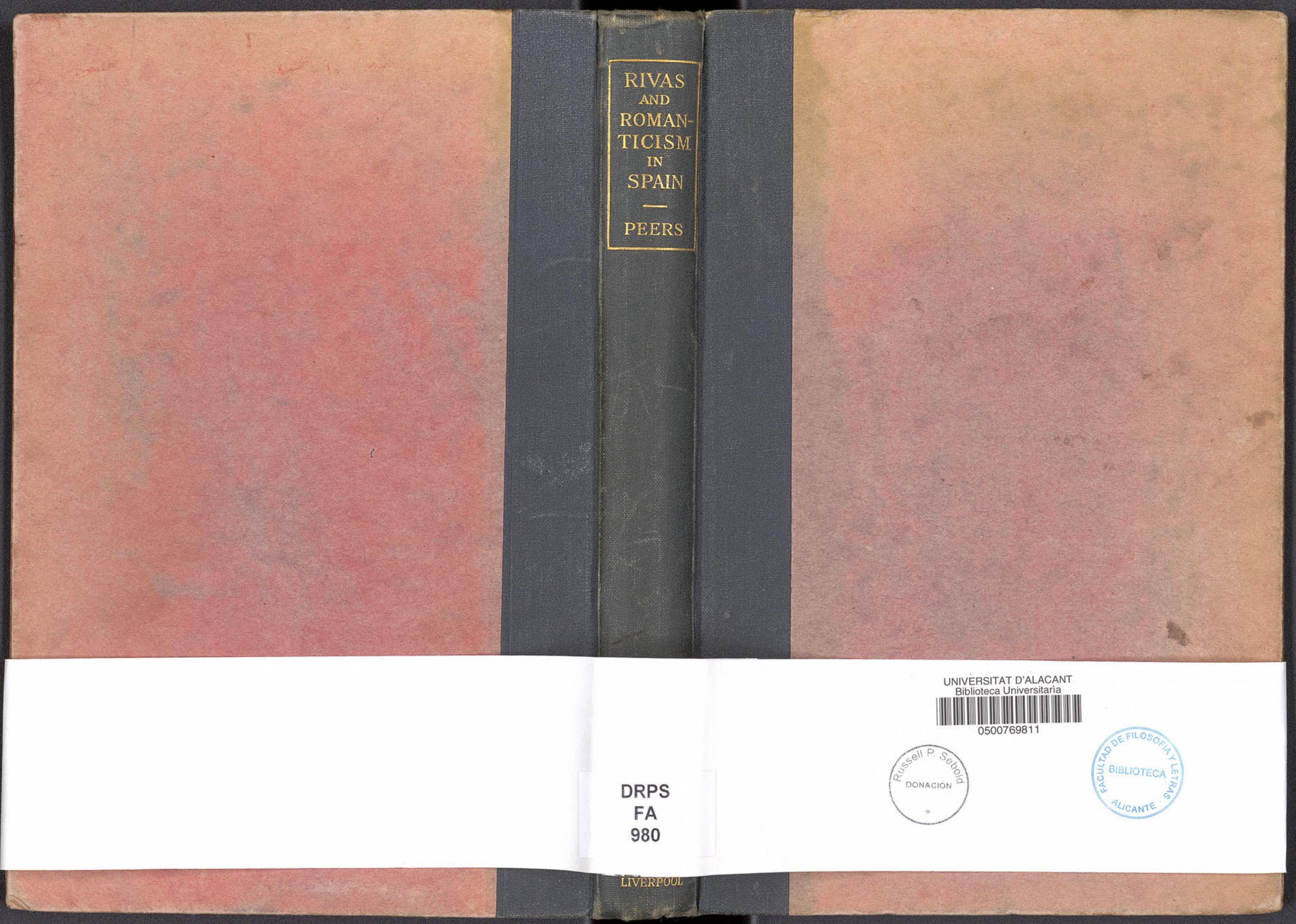




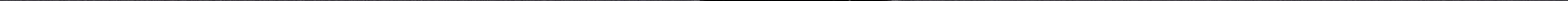





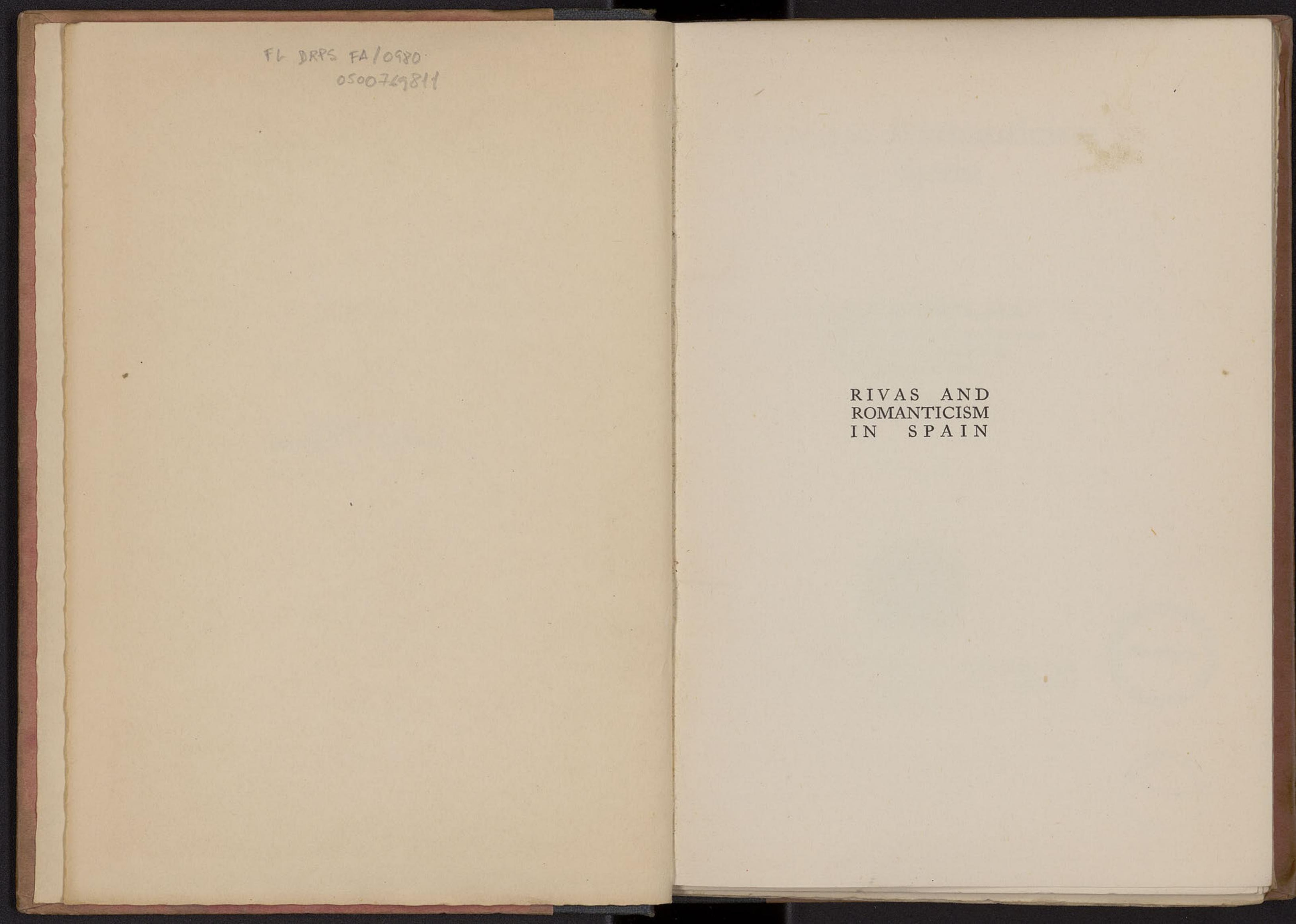




\section{Rivas and Romanticism in Spain}

BY

E. ALLISON PEERS, M.A.

Sometime Scholar of. Cbrist's College, Cambridge

Gilmour Professor of Spanish in the

University of. Liverpool

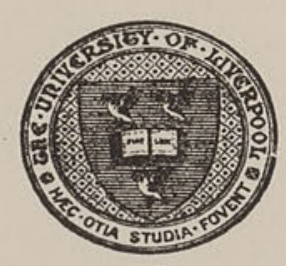

THE UNIVERSITY PRESS OF LIVERPOOL, LTD. HODDER AND STOUGHTON LTD., LONDON. MCMXXIII.

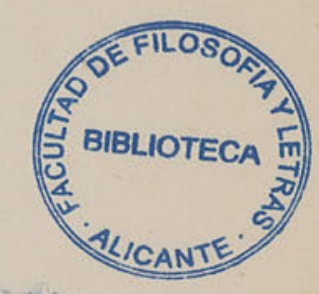




\begin{tabular}{r}
\hline UNIVERSIIA \\
UNIVERSIDAD \\
EIGLIOT \\
NO COPIA
\end{tabular}

TO

J. G. R.

BEST OF FRIENDS.

Made and Printed in Great Britain by C. TINLING \& Co. LTD. 53, Victoria street, Liverpol,
and at London and Pressot. 
CONTENTS

Chap.

INTRODUCTION

PAGE

PAR'T I

Rivas and Romanticism

I The Appeal of Rivas to his Age . . . I

II Revival and Revolt, $1834-5 \quad$. $\quad . \quad$. $\quad . \quad 13$

III A Romantic made and lost $\quad$. . . 35

PART II

Rivas and His Art

IV The Poet of Light and Colour . . . . 59

$\mathrm{V}$ The Poet of the South . . . . 80

VI The Influence of England $\quad$. $\quad$. $\quad$. 92

VII Religion . . . . . . . 112

Select Bibliography . . . . . . I3I 


\section{PREFACE}

For the last five years my special studies in the early period of Spanish Romanticism have brought me into close and constant touch with the works of that fascinating author who is the subject of this book. The Duque de Rivas has been strangely neglected, even in Spain. To English readers, other than a small body of students, he is all but unknown; it is not twenty years since Martin Hume described one of his finest lyrics ${ }^{1}$ as an " historical drama, worthy of the great times of the Spanish stage," and little progress has been made in the interval. It may be hoped that before long Rivas may be the subject of a fulllength biographical and critical study, in which not only will the literary problems of his work be discussed in detail, but also, for the first time, the merit and importance of his writings as a whole will receive just recognition.

The present volume is offered in part as an indication of the need for such a work. But it also attempts to present vividly a personality which appealed with tremendous force to Spaniards of fifty years ago, as well as to make an eminent Spanish poet better known to lovers of poetry and of Spain. In the earlier chapters some suggestions are made as to Rivas' true position in relation to the Spanish Romantic movement and the true perspective of his genius. The second part considers his varied and fruitful work with respect to its intrinsic value, which

x. The Faro de Malta (see Spanish Influence on English Literature, London, 1905, p. 307 ) 
may well in generations to come rise far higher yet above the work of his contemporaries. Its most surprising feature will probably be thought the extent, hitherto unsuspected, to which Rivas drew upon Shakespeare, Byron and Scott. But his great original talents-his skill as a colourist and his love of light no less than his gifts as a story-teller-have also passed all but unnoticed in a land so prodigal of light and so rich in colour that she can perhaps afford to take both for granted.

During these years of study I have been greatly helped by the courtesy and consideration of scholars and librarians in many parts of Spain who have allowed me free access to their stores of knowledge, and in a few cases gone to great pains to procure for me material otherwise inaccessible. When I am able to publish at length the results of the study of such, and of other material, I shall hope to make the full and particular acknowledgments which are due. But since this volume cannot fail to owe much to the acquisition of details which space prevents me from incorporating, I gladly put on record here my thanks.

The University,

$$
\text { E. Allison Peers. }
$$

LiverPool, Fune, 1923.

\section{NOTE}

All references to Rivas' works, unless otherwise stated, are to the seven-volume edition of $1894-$ 1904, and, for reasons of space, the references to volume and page are given simply thus : IV, I28without name of author or edition. References to other writers may be amplified by a consultation of the bibliography on pp. I $31-2$. 


\section{INTRODUCTION}

THE NATURE OF SPANISH ROMANTICISM

"IT may be affirmed," wrote an easy-going critic some few years ago, "that on the meaning of the word 'romanticism' there exists complete and universal agreement, and that nowadays it conveys the same idea to all."

It is possible, of course, to make such an affirmation, but few who have studied the Romantic period, even in Spain alone, are likely to support it. "Into how many controversies have scholars entered to solve this problem! And how many contradictory opinions have been given !..... 'What is Romanticism ?' the public has asked, and every scholar has replied in his own way.", So wrote Mesonero Romanos in 1837 , when the word 'Romanticism' held sway "from the Tagus to the Danube, from the North Sea to the Straits of Gibraltar" ; ; and from this point onward, as the Romantic movement recedes into the background of history, the conceptions which modern critics hold of it seem even more confused, though their judgments are naturally more dispassionate. Their efforts to twist it this way or that, and to endow it with one single informing principle-which it never

I. Enrique Piñeyro : El Romanticismo en España, p. ix. 2. "El Romanticismo y los Románticos" from Escenas Matritenses.

3. Ibid. 
xiv RIVAS AND ROMANTICISM IN SPAIN

had-are as frequent and as futile to-day as they were forty years ago, when Cánovas del Castillo exposed them. ${ }^{1}$ Until the Romantic movement in Spain receives more serious study, and an authoritative history comes to clarify the vague conceptions of its nature which prevail, such studies as the present one must be permitted a few words of introduction.

In most European literatures, the new force which dominates the early nineteenth century, and is called Romanticism, was partly transformed by having to contend not merely against genuine classical ideals, but against a conventionalism and a vicious taste which had characterised the preceding age. Spain was fortunate in this respect, for when all has been said (and it is much) about the bad taste of her eighteenth century literature, the fact remains that her Golden Age never fell into entire discredit. Hence when Romanticism came to Spain (late in time, for political and other reasons) it broke gently upon the country like a new literary awakening, instead of crashing suddenly, as it did in France, with the force of a new Revolution. It lacked the vigour and the vehemence, the overwhelming conviction of the French movement; its aims were more doubtful, its successes less marked, and the eventual reaction against it was gradual and uninspired. All these characteristics it had, but the first of them was the chief : it was less a Revolt than a Revival.

It contains little, therefore, that is negative. Its early detractors, it is true, endeavoured to discredit it as an inspiration of French extremists,

I. See 'El Solitario' $y$ su tiempo, I883, I, I22. But the author is himself (cf. p. IIg) not exempt from his own charge. a passion for the formless and preceptless in art. "Mere lawlessness," it is called by one opponent ${ }^{1}$; "Romanticism or the rule of having no rules, by another" ; " a rebellion against all principles and laws dictated by experience and the study of antiquity," says a third. ${ }^{3}$ Nevertheless, from beginning to end, Spanish Romanticism was essentially constructive. Before all else it meant a return to past ages in literature; it attempted to establish their essentially Romantic character; and sweeping into its net such dissimilar writers as Homer, Dante, Calderon, Shakespeare and Goethe, marched off with them in triumph, shouting: "These are the true apostles of Romanticism."

It was easily said, too easily to be convincing, but the Spanish Romantics were on stronger ground when they pointed to the two great springs of their own literature, and declared them to be founts whence Spanish writers of their own day should seek inspiration. Durán, in his two most famous articles ${ }^{5}$, was the first to lead the way with a sure step and a following equally assured. The Duque de Rivas, as we shall see, was among the greatest of those that came after. ${ }^{6}$

These two springs of inspiration were, of course, the mediaeval romances and the literature

I. Lista : "De lo que hoy se llama romanticismo," in Vol. II of Ensayos criticos y literarios (Sevilla, 1844).

2. Revista Española, April I2, $\mathbf{1} 835$.

3. La Estrella, January, I8 34

4. See Modern Language Review, XVI, 281-296; XVIII, 37-50.

5. The "Discurso sobre el influjo que ha tenido la crítica moderna en la decadencia del teatro antiguo español " (I828) and the "Discurso preliminar" to his Romancero de (1828) caballerescos e bistóricos anteriores al siglo XVIII (1832). 
(especially the drama) of the Golden Age. Both were indeed worth fighting for, and the one sentiment which did inspire the Romantics of Spain was that of patriotism. All Durán's prefaces to his collections of romances strike the patriotic note. "Love for my country," begins one, "has sustained me to the end in this task, so beneficial to the public, so difficult, arduous and destitute of glory for myself."1 Elsewhere he says he is reprinting these romances for very shame, lest Spaniards should have to study their own writers in foreign libraries, ${ }^{2}$ or again, that he longs to form " a truly national collection of poetry, that has sprung up and flourished in our country, and owed nothing to the foreigner."3 Every page of the great "Discourse" of 1828 breathes the supremest pride in the achievements of the Golden Age in Spain, or contempt for those who, consciously or not, have belittled them. His eloquence becomes lyric when he reminds his readers how conquering Spain pursued the Arabs, driving them little by little back to the sea-" to Afric's burning climes"-how the Spaniards utilized the civilization of their former oppressors, and united to it the products of their own genius, and how, when the rest of Europe had barely emerged from the darkness of ignorance, Spain was laying the foundations, not only of power and prosperity, but of the literature of her Golden Age. The note of triumph is unmistakeable, and we can forgive the champion of Spain if occasionally he eyes the "rest of Europe" awry.

" "Discurso preliminar" of 1832 .

2. Prologue to Romancero de romances moriscos (1828).

3. Prologue to Cancionero y Romancero de coplas y canciones de arte menor (1829).
But the "Back-to-Lope" movement and the reprinting of romanceros were not the only signs of Romanticism in Spain. The influence of foreign literatures was enormous upon a country whose Romantic movement was almost the last in Europe. The emigrations of $1814-20$ and I $823-33$ sent the foremost progressive minds in Spanish letters to study in England and France, where Romanticism came early to the birth. Scott, ... Byron, Victor Hugo, can all be shown to have invaded the Peninsula and taken it by storm:1 "Ossian," Chateaubriand, Lamartine, Southey, Moore and others penetrated more or less deeply also. As to Italy and Germany, not only were individual authors of these countries continually cited by the Spanish Romantics as their predecessors, but more than once was the one country or the other described as the soul of the European movement considered as a single phenomenon.

Of the catch phrases which popularised the movement in Spain none is more frequent in the journals of the time than Hugo's famous dictum that Romanticism is liberalism in art. His determined antagonism to the ideal of restraint is echoed throughout literary Spain. His resolve to use all subjects freely, whether beautiful or ugly, ancient or modern, distinguished or commonplace, is stoutly upheld by Alcalá Galiano in his preface to Rivas' greatest romance. In the same preface we find ideal upon ideal which might have sprung from the Préface de Cromwell, or the less known prologues to Ruy Blas, Lucrèce Borgia, Vigny's Chatterton or

r. See (e.g.) Revue Hispanique, Vols. XXIII, L, for Byron, and Vol. LIII for Scott, the most important of all. 
Hugo's volumes of poetry. Let the reader but judge for himself :-

The author has endeavoured to give to his work the colour which belongs to it, consulting, with this end in view, the few documents which still exist relating to the times in which the

events he describes took place.
He has purposely avoided all allusions to the mythology of classical antiquity.

He has mingled (if he may so express it) burlesque with realism, unpretending fragments with brilliant passages, pages of lofty style with others undistinguished, trivial images with noble, realistic pictures with scenes that are purely ideal. No nomall proportion of his readers may perhaps be offended by this; the fault is not his but Nature's... He would take Nature for his guide and describe things as they are.

The follo The following work is detics have repentedly condemned, and which the best contemporary poets in all Europe have neglected. 1

There follows a list of ten rules which the author has followed, and which we shall have to consider in due course.

Such as these were the principles of Spanish Romanticism, but this sketch would be at best but an insufficient one were it anything more than a preface to the more specialised study which follows. It attempts to set forth only the leading ideas of the movement, and to place in something like true proportion certain elements which some preceding writers have thought to over-emphasise or entirely to neglect.

\section{PART I}

RIVAS AND ROMANTICISM

I. III, xxxi ff. 


\section{CHAPTER I}

THE APPEAL OF RIVAS TO HIS AGE

ON the 23 rd of June, 1865 , Madrid was thrown into mourning. Angel de Saavedra, Duque de Rivas, was dead.

His death was not unexpected. $\mathrm{He}$ was seventy-four years of age, and for some time past had been suffering from a painful and incurable malady. Six months earlier, when the Queen had bestowed on him the Collar of the Golden Fleece, he had been too ill even to rise in her presence, and had spoken of himself as a "dying man."1 And now that the struggle was over, any inhabitant of the capital might have been forgiven had he perused the newspapers with scant curiosity to see how the event was regarded. Here was a man whose brilliant and diversified gifts had made him conspicuous both in the literary and the political world, even as his birthright had placed him in the forefront of society. For almost thirty years he had been planted upon a pedestal before which the people were accustomed to bow down, save at occasional brief intervals when they endeavoured to depose him. Duke and peer of the realm, ambassador to two great foreign powers and signal favourite of royalty, he was also a prince of letters, the protagonist of Romanticism in Spain, an innovator who, though the vogue of the movement to which he set the seal was short, won for himself in popularising it a position of pre-eminence.

I. $\mathrm{I}, \mathbf{1} 38$. 
Why, then, should there be any curiosity about the verdict of the country which mourned his loss ? When so venerable a figure passes, there is commonly a chorus of lament which, unanimous as it may be, betrays the sense that the event was, after all, a necessity of fate. There is a certain remoteness in the comments of the press, a feeling that they were ready in a pigeon-hole awaiting the news of decease.

But the student who visits the National Library at Madrid to-day, and, turning up the relevant press files, endeavours to reconstruct the effect of Rivas' death, will be amazed at the result they disclose. There is a sense of complete prostration, of irreparable personal loss, of a country "inconsolable, sighing for him she mourned."1 This peer of the realm, this ambassador and courtier, this acknowledged father of literary Spain, has captured not only the allegiance of his country, but her affections. And further investigation reveals the cause. The elderly nobleman was no sooner dead, than from the public mind his image faded. In its place appeared the figure of a patriotic young soldier-poet, worthy follower of Lope and Cervantes, simple and frank by temperament, who had lived through the stormiest years of the nineteenth century, and been forced by fate into playing many parts, as varied and startling as they were numerous.

At once soldier and poet, he has maintained the glorious tradition of our literary history: he is the truest incarnation of our national spirit, for he wielded both pen and sword. ${ }^{2}$

He was the principal champion of our literary regeneration,

I. Museo Universal, IX, 231, July 16, 1865

2. Museo Universal, IX, 210, July 2, 1865. the hero who fought for his country with the sword, though he honoured her with the pen. 1

One of the most fertile, spontaneous and brilliant poets who have honoured the Spanish nation. His life has been varied, romantic, full of poetry and adventure ....2

So the notices run on, all in a similar tone, eulogising, not the august personage of whom a noble house has just been bereft, but the dashing young hero of events which happened forty, fifty years earlier, who by some surprising gift of nature has contrived to keep himself eternally young and entirely unspoiled by fortune.

Let us review those events, and attempt to discover Rivas' secret.

Born in I79I, ${ }^{3}$ a second son, left fatherless and heir to his brother's dukedom at eleven, Angel de Saavedra began his career in the army at a time when the Napleonic invasion was already foreshadowed. At every stage in the conflict he showed himself the embodiment of patriotic zeal. He was with the Royal Guards in the Escorial at the time of the imprisonment of Prince Fernando, and acted as their spokesman when they refused to obey Murat, and put down the insurrection in Segovia. When his regiment broke up, he went with the Duke, his brother, to join Palafox at Zaragoza, - then changed his plans, spent several adventurous months, and took part in the battle of Talavera (1809).

In the autumn of this year took place the incident which, even after fifty years, Rivas' admirers never quite forgot. The brothers were

I. Periódico Ilustrado, No. I7, June 29, 1865.

2. Revista bispano-americana, III, I40-I, June 27,1865

3. For a circumstantial life of Rivas-not always, however, satisfactory-see I, I-I 4 I. 
fighting in a cavalry engagement some thirty miles south of Madrid. D. Angel's horse was wounded; and the lad himself, after fighting for some time on foot, received three wounds also. Falling to the ground, he was unnoticed in the retirement of his force on the main body, and was left behind for dead. When he came out of his swoon, he found himself stripped by the enemy, with only sufficient strength to call to a passing soldier who carried him to safety. A sharp illness and a wearisome convalescence followed, during which the boy wrote the autobiographical lines beginning

$$
\begin{aligned}
& \text { Con once heridas mortales, } \\
& \text { Hecha pedazos la espada, } \\
& \text { El caballo sin aliento } \\
& \text { Y perdida la batalla. }
\end{aligned}
$$

The simple verses struck the Spanish imagination, and D. Angel's experience was not allowed to be forgotton.

Meanwhile, the invasion was proceeding southwards. Córdoba was entered, and D. Angel, who was resting there, fled with his mother to Málaga; and, when this was attacked also, to Gibraltar and thence to Cádiz. Here he remained, through the momentous days of siege and beyond them, until he was well enough to re-engage in active service. Soon after this, the French were driven from Spain.

During the first emigration D. Angel was unmolested, and he had ample opportunity to develop his literary propensities. A slender volume of verse (1814), the dramas of Ataulfo, (I8I4), Doña Blanca (I8I5), and Aliatar (1816), a second collection of poems in two volumes (1820)

I. I, 2II-3. including two new dramas (El Duque de Aquitania and Malék-Adhél) bear witness to his energy. In I822, however, he was elected deputy for Córdoba, and his adventures began once more. An ardent and courageous Liberal, he soon distinguished himself by his passionate speeches: within eighteen months of taking his seat, he was under sentence of death and in flight towards Gibraltar. "I fled, a fugitive and a proscript," he writes, "from that country for whose independence I shed my blood, for whose liberty I have forfeited my life."1

The King had regained his freedom, and the foremost Liberals of Spain were establishing themselves in England or in France. But Saavedra, for a time, could find no home. $\mathrm{He}$ wintered at Gibraltar, then spent six months in London, left on account of the rigorous British climate, for Italy, was forbidden for political reasons to settle there, and finally embarked for Malta, where he remained nearly five years.

A later chapter will describe D. Angel's life in Malta, the friendship which he formed there with John Hookham Frere, and the writing of his great verse-romance El Moro Expósito. Here we need only follow his troubled life until peace and freedom came to him with the death of Fernando, in 1833 . It was three years before that event that he determined to visit France with his wife and three little sons, all of whom had been born in Malta. But as soon as he set foot in Marseilles his anxieties began once more. A reactionary government had succeeded to power, and instead of proceeding to Paris,

I. Discurso de Recepción leido en la Real Academia Española la tarde del 29 de Octubre de 1834 . 
D. Angel had to take refuge at Orleans, where, almost without means, he made a precarious living by taking pupils until the July Revolution enabled him to go to Paris. Thenceforward, in the capital and in Tours (where an outbreak of cholera sent him) he lived between uncertainty and want until the general amnesty which followed the King's death allowed him to return to Spain at the beginning of $\mathrm{r}_{834}$.

These are some of the events which the Spanish public remembered after thirty years. It must be admitted that their hero did his utmost to keep their memory fresh. He had ever an eye to the picturesque, and it pleased him to see himself, and to be seen, in his uniform of 1808 , "that memorable year in which our country regained its greatness, and became Spain once more."1 So in public speeches, autobiographical poems, prefaces to plays and romances, and articles in the press, he rehearsed again and again the adventures of his years of war and exile and successfully evaded the doom of aristocratic respectability to which Fortune worked her hardest to condemn him.

For with the amnesty the life of D. Angel de Saavedra ends, and we enter upon that of the Duque de Rivas. Four months after D. Angel's return to Spain, the death of his elder brother without issue left him successor to the title, at a moment when his Moro Expósito (1834) had made him famous as a writer, and, with the startling drama Don Alvaro (1835), was shortly to raise him to the premier place in contemporary Spanish literature. He was proclaimed (whether

I. Discurso de Recepción leido en la Real Academia Española la tarde del 29 de Octubre de 1834. justly or no) as the chief of the new Romantic movement in Spain. Had he taken this opportunity, accepted the title and settled down to a literary life, it is hard to say what heights he might not have reached. Unfortunately for the world of letters, he chose that career which his succession to the dukedom marked out for him. Apart from a few indifferent plays, a handful of lyrics, a collection of verse romances and three verse legends, he produced nothing more which belongs to pure literature, and the literary honours which came to him (he was first president of the Ateneo, and a member-afterwards Director-of the Academy) may be attributed mainly to his two chefs d'oeuvre.

"He was born to be a poet," said Gustavo Becquer of Rivas, after the latter's death, " and a poet could be a soldier, but never a politician!"

Nevertheless, if not to the manner born, the Duke engaged first in politics, and afterwards in diplomacy. His extreme radical views he exchanged for more fittingly moderate ones. He played an important part in several successive governments, and more than one political crisis; in 1844 , he was appointed Spanish Ambassador at Naples, where he remained for six years. On his return to Madrid he was able for some time to take a less active part in politics than before, but in 1859 he was sent as Ambassador to Paris, where he stayed until failing health obliged him to resign his duties.

If it was the youthful patriotism of Angel de Saavedra which endeared him to the Spanish people, his singularly attractive personality, which had small chance of revealing itself to them

I. Museo Universal, IX, 210, July 2, 1865. 
during his exile, accounted for the universal popularity of the Duque de Rivas. Physically, at least, he might have been aged by his experiences at home and abroad, but in spirit he never grew old. As a boy of nineteen in Cádiz "his wounds, his vivacity, his kindliness of nature and his pleasant, jovial manner gained him the affection of all his companions."1 Of the man of fifty, Ambassador at Naples, an attaché wrote: "One would have thought him endowed with perennial youth, so light-hearted was he and so consistently good-humoured. $\mathrm{He}$ himself used to boast of being younger than all his secretaries and attachés." ${ }^{2} \mathrm{On}$ his death men could still say of one who had remained a boy in spirit, unspoiled by all the honours he had won: "Everyone who knew the Duke will feel the greater grief at his death for the kindness and affection with which he treated them; they will ever miss his delightful conversation, his endless store of witticisms and jests, his tireless skill in inventing anecdotes, tales and adventures, and his wonderful talent for relating them."3 Wherever he went-to his home at Sevilla, to his palace in Naples, to his town house in Madrid, -he was certain to become the centre of an admiring and devoted circle-not of flatterers and hangers-on, but of friends. During his long exiles, and at those crises when he was in danger in Spain, he won himself willing helpers on all hands. When prosperity came he became himself a willing helper of young authors like Valera and Zorrilla, neither of whom could eve

\section{I, 35 .}

2. Juan Valera, p. 193. cf. Cueto, p. 593 and Rivas, II, 298

3. Revista bispano-americana, III, I4I, June 27,1865 . express his affection for the Duke with sufficient warmth.

'Thus Zorrilla, long after Rivas' death, describes his first visit, when little more than a youth, to the eminent poet, who was just then enjoying the first full honours of his literary fame; and his words are full of meaning:-

How fresh is the memory of that journey and my stay in the house and family circle of that great poet, who became to me house and faily ! Posterity may call him the Duque de Rivas, but for my part I call him my rood 'Angel'? the remembrance of his friendship lives still in my heart. ${ }^{1}$

Of the day of his first meeting with the Duke he writes:-

"It was one of the few days in my life which I can count as happy, and my happiness reached its height when, in the evening, I was presented to the famous poet .... The memory of the kindness which I received in the Duque de Rivas' home is a haven in the troubled sea of my existence."

How strikingly the homely evenings in that happy Sevillan household must have contrasted with the nightly dispersal of the ordinary family to whom a home means no more than a lodginghouse! Every night they would gather round a large table, the ladies with their work, the boys reading or sketching-easel, sketch-book and piano were always open-and Rivas himself now and again reciting one of his own romances, or some legend which he had disinterred in his rambles about the city. ${ }^{3}$

Such scenes as these inspired the simple lines in which Zorrilla, playing once more upon his hero's name, summed up better perhaps than

I. Zorrilla, I, I30. The book appeared in 1880 , but the day referred to in it was April 1,1842 .

2. Ibid., p. 136 .

3. Ibid., pp. $138-9$. 
anyone else has done, the other half of the secret of Rivas' personal appeal to those who knew him :-

$$
\begin{aligned}
& \text { Sencillo y sin arrogancia } \\
& \text { Con su corazón sin hiel, } \\
& \text { Le llamban Ángel, y él } \\
& \text { Era ángel siempre en la infancia. } \\
& \text { Porque llegó a envejecer } \\
& \text { En una vida de niño } \\
& \text { De poësía y cariño, } \\
& \text { Sin dejar de niño ser. }{ }^{1}
\end{aligned}
$$

Here, then, we seem to have penetrated to the depths of that personal appeal. And we may ask the further question: How did Rivas appeal to his age as a writer?

"He was an initiator," it will be said-" a great Romantic." True enough : every schoolboy would know, if schoolboys learned such matters, that "Don Alvaro has been called the Hernani of Spain." (It has, and, as we shall see, none too happily.) But Romanticism, long before 1865 , had passed away as a self-conscious literary movement. ${ }^{2}$ Its protagonist might find a place by virtue of that position in a manual of Spanish Literature, but assuredly not in a Spanish heart. Yet his writings reached the hearts of his countrymen no less than did his personality, and for similar reasons.

His attractiveness and geniality shone radiantly in his writings. He could tell a story in a volume of verse no less skilfully than round the fireside. $\mathrm{He}$ could make friends by his kindly writings as easily as by his kindly words. He could paint pictures in romance and drama, warm with colour, suffused with light, and glowing with the

I. Zorrilla, cit. in Rivas, I, 164-8.

2. See an article by the present writer in Modern Language Review, XVIII, $37 \mathrm{ff}$. enthusiasm of youth. No such writer ever failed yet to appeal to a few, nor, with Rivas' genius, to many.

And then he was a poet of Spain. All his works, with hardly an exception, have his country for a background; in many of them she is his favourite character, the heroine of his fancy. The foreigner can gaze upon her landscapes in Rivas' poems as in those of few others; he can listen to the patriot's eloquence in the lyrics and romances; he can mix with living and breathing Spaniards in the dramas. In some respects, Rivas ceased to be a Romantic writer after his return from exile $;^{1}$ but he never once ceased to be the poet of Spain. On the contrary, his later work combines the maturity of age with the ever-living enthusiasm of youth in a way that exalts patriotism in art to the highest degree of which it is capable. In almost his last known poem, partly written (never, in fact, completed) ${ }^{2}$ from a bed of pain, his mind roams back over the past to that day when he was left for dead on the field of Ocaña. And all his boyish ardour returns to him as he remembers not his weakness, but his strength.

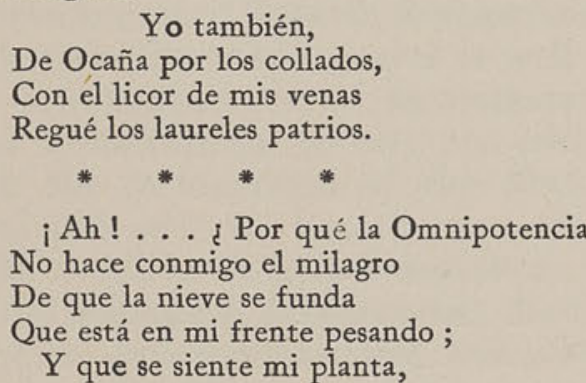

I. See Chapters II and III below.

2. I, I36-7. 
Y que se afirme mi brazo, Como un tiempo memorable Bajo el invicto Castaños ? 1

In such a blaze of dying fervour was that magnificent spirit extinguished. It could hardly fail to kindle the enthusiasm of his country.

I. II, $339-40,336$.

\section{CHAPTER II}

REVIVAL AND REVOLT, I834-5

To see Rivas, however, in the popular light is in no way to realise the peculiar nature of his genius. He is generally known, and will probably go down to history, as the protagonist in Spain of the Romantic movement. How far such a title is justly his-how far, indeed, he is a Romantic by conviction at all-which of the two aspects of the movement, if either, he represents-to what extent he remained true to it after its decline : these are literary problems of the deepest interest, and we shall consider them in the present chapter and that which follows. Then, taking up his work and studying it intensively and intrinsically, we shall attempt to evaluate the outstanding qualities of his genius, and certain other prominent but neglected elements in his writings.

The compositeness of Spanish Romanticism, its dependence upon the exotic genius as well as the native, its double character of an awakening (or revival) and a reaction (or revolt), are admirably reflected in the productions of the Duque de Rivas. And not only so, but the two elements appear in his work in historical sequence. That of revival was a gradual development during the long period of pre-Romanticism and came to a head about 1828 : a corresponding growth will be perceived in Rivas' early works, culminating in the production of his first great masterpiece 
in 1834 . The element of revolt, as was natural, made its appearance more suddenly; and the work which gave it being was the second masterpiece of Rivas, produced in 1835 . The singular service, then, which he rendered to Spanish Romanticism was the combination of its two characteristic elements, and, at the psychological moment when Spain was waiting for a literary leader, the production of a chef d'oeuvre in each of them.

The first of these was the Moro Expósito, a long verse romance begun in Malta (1829), finished four years later in Tours, and published in Paris in 1834. It is based upon one of the oldest themes in Spanish literature, the story of the seven sons of Lara, and of Mudarra, the "Foundling Moor" of the title. ${ }^{1}$ From cantar de gesta, through chronicle, ballad, novel, romance and drama, this virile and arresting legend, so rich in all the elements of tragedy, yet withal so pathetic and so human, has come down in varying expressions but with its unchanged barbaric heart. It is hardly likely to find more enduring expression than in the Moro Expósito; nor could Rivas well have chosen a theme with its roots more deeply embedded in the national soil or more closely identified throughout the centuries with the history of the national literature.

The different versions of the legend present many variations in detail, but a sketch of the main theme, which varies but little throughout, will suffice to show the poignancy of its appeal, and the opportunity which it would give to the

I. Sr. Menéndez Pidal (in La Leyenda de los Infantes de Lara, Madrid, 1896) has with the greatest skill reconstructed the cantar de gesta, no longer extant. modern poet. We are in the tenth century, at Burgos, where the marriage of a noble called Rodrigo (or Rui) Velázquez to a certain Doña Lambra is the occasion of great rejoicings. Among the guests are Doña Sancha, Rui Velázquez' sister, the wife of the noble lord Gonzalo Gustios de Lara and the mother of his seven stalwart sons. During the fesrivities a dispute arises, and Gonzalo González (often termed Gonzalvico), the youngest of the seven sons, attacks (and in some versions kills) Alvar Sánchez, Doña Lambra's cousin. Peace is made, but Doña Lambra still cherishes rancour. She sends a servant to insult Gonzalvico by throwing at him a cucumber filled with blood; the infantes retaliate by killing the servant before his mistress' eyes-for he has run to her for protection-and Doña Lambra, deeply outraged, complains to her husband, who promises her that the deed shall be avenged.

He lays his plans craftily and well. Feigning to the infantes that all has been forgiven and complete friendship restored, he prevails upon their father to carry to Almanzor, the Moorish "King" of Córdoba, a letter written in Arabic which, unknown to its bearer, is a recommendation to kill him and an undertaking to lead the infantes into an ambush where the Moors may slaughter them. Almanzor, instead of killing Lara, imprisons him, and after the infantes have been murdered, and their bodies decapitated, he makes a present of the seven heads to the unhappy father, whom he finally allows to return to Castile. During his captivity, however, Lara has been attended by Almanzor's own sister, and after his departure she bears him a son, Mudarra. This boy, when grown to a reasonable 
age, determines to avenge his brothers. $\mathrm{He}$ journeys to Castile, discovers his now aged father, challenges and slays Rui-Velázquez in a duel and metes out fitting mediaeval retribution to his aunt, who, in some versions, is burnt alive.

This is the outline of the story which Rivas took as the basis of his romance, embellishing it in some parts beyond recognition, but retaining all its most characteristic features. When the new poem first appeared, ${ }^{1}$ it bore the sub-title "Córdoba and Burgos in the tenth century," and one of its author's first cares (for he had the true Romantic passion for antithesis) was to divide the book into two parts, greatly enlarging the second part of his original, with settings respectively Moorish and Christian. Accordingly the story opens, not in Burgos, but in the South, where Mudarra appears as a boy of nineteen, of unknown origin-supposed to be a foundlingand enamoured of Kerima, daughter of Giafar, a former bagib (or premier). The whole of the story leading up to the murder of the seven sons has, therefore, to be related, and it is a tribute to the author's powers that it loses in the process but little of its tragic force. After two cantos of this narrative the thread of the story is resumed, where Mudarra, knowing now his father's wrongs, determines on revenge.

Into the first five cantos (there are twelve in all) which form the Cordoban part of the poem, are introduced several characters of Rivas' own invention. The lovely Kerima, who is one of them displays the usual virtues of a mediaeval maiden and is conspicuous for little save a dog-like

I. In the Paris edition of 1834 : the sub-title was later dropped, perhaps unfortunately. devotion to her lover. "Mudarra is her existence, her world " comments the poet. ${ }^{2}$

Siempre fijo

Un pensamiento solo la domina :

Mudarra nada más."

Giafar, her father, supplies the element of villainy in the early part of the romance: some have thought his introduction superfluous, even inartistic. More important among Rivas' creations is Zaide, the seer to whom Mudarra's education has been entrusted, and whose whole personality is suggestive of mystery and awe. It is he who relates to the Foundling his brothers' tragic story, and eventually accompanies him to his father's home, thus forming, as it were, a link between the two parts of the narrative.

But more significant than the creation of these characters is the transformation of Mudarra, from the muscular skull-splitting young barbarian of the chronicles to a curious combination of warrior and Romantic hero. Nature has endowed him at birth with her choicest gifts, adding the quality of prudence to the blessings of virtue and strength. He is modest as well as brave, cautious as well as daring, and happy in the constant and devoted affection of Kerima. Yet, to the reader's astonishment, he proves to be as sensitive and emotional as any René. Nature affects him visibly $;^{3}$ thinking on his mysterious origin sends him into melancholy abstraction ; $^{4}$ Zaide's story he hears with a display of emotion such as any

I. III, 65 .

2. III, 208.

3. E.g., III, 330 
young Romantic might covet $;{ }^{1}$ when finally he sees the gorgeous chest containing his brothers' heads, he throws himself on it, kisses it repeatedly and bathes it in a copious flood of tears. ${ }^{2}$ As for the terror which seizes him when he finds that, unwittingly, he has slain Giafar, is this the attitude of any mediaeval Mudarra?

Mas ; en qué situación llega el mancebo !

Oh santo Dios, en qué terrible estado!

Pálido, alienta apena, en torno gira

Los ojos, que terror pintan y espanto ;

Descenido el turbante al viento ondea,

Desnudo el hierro muéstrase en su mano;

$Y$ hierro, y mano, y manga, todo es sangre

$\mathrm{Y}$ sus miembros temblor, nieve su tacto.

Alza la faz, lanza un gemido, y dice :

"Al padre de Kerima muerte he dado."

$\mathrm{Y}$ con nuevo terror quiere esconderse

Del tierno Zaide en los amigos brazos. ${ }^{3}$

The second half of the story is considerably more elaborated than the first-the sources stop short for the most part at the meeting of Mudarra and Rui-Velázquez, the challenge and the duel. Rivas obviously had to improve on this, for in the early cantos the Christian characters had only been introduced as the persons of a narrative within the story, and lacked that life and reality which he knew so well how to convey. Accordingly the greater part of one canto is devoted to Lara, the old father, and his story, additional pathetic force being given him by making him not only old but blind. With him is Nuño, the former tutor of

I. E.g., III, 142, 1.2; $163,1.20 ; 167,28-9$. Also pp. 99 , 105, I. E.g., $111,142,1.2 ; 163,1$
$141,166,168,175,202$ passim.

$41,166,168,175,202$ passim.

2. III, 175 . the infantes, whose rather prolix account of his travels in Egypt and Palestine is perhaps of less interest than he (or his creator) thinks. ${ }^{1}$

To these enters Mudarra (with Zaide) closely followed by Rui-Velázquez; there follow the recognition and the challenge (as in the sources), and the poem would seem to be near its end. But Rivas has more to do yet : a mere common duel, fought on the spot, as in drama the Unities might make inevitable, would be an inadequate conclusion to a poem so lengthy and elaborate. Besides, we know nothing yet at first-hand of Rui-Velázquez, the arch-villain, while Kerima, who must certainly play an important part in the denouement, is still in the south.

So the necessary month which elapses between challenge and duel is crowded with significant happenings. The proper heroic light is shed upon Mudarra by his legitimation according pathetic likeness to the youngest of the murdered brothers, and the various attempts which RuiVelázquez' agents make upon his life. The villainy and cowardice of Rui-Velázquez are enhanced by the description of his terror at the thought of the combat and the attempts which he makes to escape it. While the certainty of his impending destruction is suggested by the narration of his past history, and foreshadowed by the ill-success of his crude efforts to bribe the Almighty.

The account of the actual combat is not lengthy, nor could it be so, since the result is a foregone conclusion. It is drawn out with some

I. Nuño also figures, under different names, in many of the possible sources of the Moro Expósito. 


\section{RIVAS AND ROMANTICISM IN SPAIN}

skill by various small devices ${ }^{1}$ which for a brief moment make the villain's escape seem possible. Other details combine to elaborate it also-the motif of Almanzor's scimitar, with which Mudarra finally cuts off Rui-Velázquez' head, the appearance of Elvida and the shock which robs the villain of his advantage, and finally Kerima's presence, which heralds the last scene of all.

And this, even to the most careful reader, is a surprise. For after the baptism and at the very wedding of Mudarra and Kerima the bride suddenly cries that she will be the bride of Christ alone, for Mudarra, greatly as she loves him, was the means of her father's death!

So unconventional and unexpected a development did not escape criticism, even in the first flush of enthusiasm for the poem. ${ }^{2}$ But the reception of the poem as a whole was in every respect satisfactory. Not only was it welcomed as a spirited treatment of a great national theme, and recognised as being intrinsically an attractive work of art, but at least some conception was shown of its true literary importance. The prologue, written by Alcalá Galiano (though it appeared anonymously) disclaimed for the poem the title of "Romantic." But that mattered little, for Romantic it was recognised as being, and Romantic, in any known sense of the word, it was.

Some of the positive and negative tenets of

I. Such as Rui-Velázquez' delay in appearing on the scene I. Such as Rui-Velazquez'
of the combat (see III, 489-493)

2. See Revista española for May 23-4, I834; the criticism is discussed in an article by the present writer in Studies in Philology, July, 1922, pp. 308-316. Enrique Gil, Pastor Diaz, and Mazade are among those who condemn the denouement. Cañete (op. cit., pP. 47-8) defends it.
Romanticism which Alcalá Galiano laid down on behalf of Rivas we have already quoted. Let the case be clinched by the enumeration of those ten "rules" which Rivas set himself to follow:

The author has endeavoured to quicken his readers' curiosity as to the narrative and his affection for the characters; to suit his style to the argument both in the work as a whole and in each of its parts; to adapt it to the persons through whose moths he is speaking; to outline and colour his pictures mouths hescribe objects which re (or were) real and actual, or which might be so; to represent reteris the characteristic and natural whe ideal, for this will give the whenever he ventures the imaginary, being a semblance of appearance of foses himself clearly, when he can with purity, reality; to express himell clenty, wut always correctly; to sometimes gracefully and elegantly, but all to follow his own versify as well as he is able; impulses, to obey spontancous in piters of the present time.

to emulate the greatest fore believe, being conceived and formulated first! We cannot refrain from placing beside it a few characteristic French utterances, so similar both in letter and spirit :

Il n'y a ni maître ni école en poésie; le seul maître, c'est celui qui daigne faire descendre dans lhomme lémotion fecondefois. $^{1}$

Un imitateur de Shakespeare serait aussi faux dans notre Un imiteur de Shatare d' Athalie ${ }^{2}$

Que le poète se garde de copier qui que ce soit, pas plus Que le poète donc aille où il veut, en faisant ce qui lui plaît c'est la loi. Le poète est libre."

Yet this poem was not "Romantic"! No, indeed!

I. Alfred de Vigny : Preface to Chatterton (1834).

2. Alfred de Vigny : Lettre à Lord . . . (1829)

3. Victor Hugo: Préface de Cromwell (1827).

4. Victor Hugo: Preface to Les Orientales (1829). 
22 RIVAS AND ROMANTICISM IN SPAIN

How could the importance of a work with such a preface be possibly overlooked ? And it was not. Everywhere the Moro Expósito was greeted as something entirely new, yet as something which looked back to the old. "It was a poem which had no precedent in our literature," writes a later critic, "It is unique of its kind even to-day." And he is only echoing the preface of the poem itself, which says: "The author is pointing out a path which until now has been untrodden by his compatriots, and in his audacity he has ventured to tread it himself." 2 Self-assessed then, the poem was received as an innovation; yet for all that its success, though undoubted, was quiet rather than startling.

Far other was the effect produced by Don Alvaro, when, in 1835 , upon an unsuspecting public, Rivas launched that tremendous play. We say " unsuspecting," because the author had given no sign, either by drama or other earlier work, that he contemplated staging so unusual a production. But there were evidently those who knew, and among them was a journalist. "So far as we can gather from the vague idea we have of its plot," he wrote on the eve (March 2Ist, 1835) of its appearance, "there is no doubt that it will be romantically romantic."3 It was.

What effect would a play like Hernani or Ruy Blas (for such was its type) produce upon an impressionable public in a country where Romantic ideals were strong? To those who know the

I. Juan Valera, op. cit., p. 162. Cf. I, 62-3 and Cañete, op. cit., pp. $44^{-5}$

3. Correo de las damas, March 21, 1835. (Italics ours) Various confirmatory details are given. force and appeal of this play on the stage, and not merely from description and reading, there can be but one answer. Had Madrid, as a whole, been ready to welcome that form of Romanticism which Don Alvaro introduced, Madrid would have been taken by storm. The play would have enjoyed an unparalleled runits imitators, until the inevitable reaction came, would have held the stage-and Rivas would have repeated his experiment again and again, instead of writing dramas (as he did) of a totally different type. Violent opposition, from a minority, there might have been, but in the end this would have been beneficial. No play can be imagined which was better fitted to lead a successful revolution than Don Alvaro.

That honour, however, it was not to have, though perhaps it was at least as worthy of it as Hernani. Undoubtedly it produced a tremendous impression, but rather on its own merits than as being typical of its kind. The fact is that Spain was far more interested in the national aspect of Romanticism than in the exotic; and, while the merits of the rival schools in drama were a sufficiently interesting subject to the literary public, there was no general enthusiasm for a revolution. Probably all parties would have agreed, had they been pressed, that this extreme type of Romantic play was too far removed from the Spanish tradition to prevail in the end, and at the same time that the severely classical play was equally dead.

With exactly what reception the drama met, it is strange to relate, we do not know. The common notion is that at first a pitched battle was fought between the partisans and the opponents of Romanticism; that after a short 
time, variously estimated at from days to months, the quarrel subsided; that the merits of Don Alvaro were thereupon universally allowed, and the type for which it stood prevailed for a generation. None of these statements is quite exact, and the last is entirely false.

It is unfortunate that such wild statements have been made, and so few researches pursued into the facts. For the effect of Don Alvaro upon literature, if such facts as can be ascertained speak truly, was far less dramatic than is supposed. It undoubtedly astonished both critics and general public by its bold out-Hugoing of Hugo. It impressed the groundlings by its metaphorical thunderings and lightnings, and more cultured spectators by the quality which more than justified its suggestive sub-title $T$ he Force of Destiny. Verdi, it may be remarked, saw his chance here and took it. But Don Alvaro was a nine days' wonder : almost literally so, for the actual number of its performances appears to have been eleven. ${ }^{1}$ The theatre was apparently well filled; the press was throughout, on a balance of testimony, quite favourable; the play, without being powerful enough to impose its type on contemporary drama, had undoubtedly some influence; and its intrinsic merits are likely to retain for it in literature the place which a literary legend has helped it to acquire.

The "battle," it should be added, did take place: but it was one of paper swords and slinging of ink-a press battle, in fact. The principal combatants were a conservative journal

1. Azorín (op. cit., p. 69) curiously makes it twelve : from his own account, however, as well as from other evidence, he his own account, however, of rather more weight than its title " The Ladies' Mail" (Correo de las Damas) would suggest, and Mail "Correo de las Damas) would suge "Bee" a progressive little organ known as the "Bee" (La Abeja). The Correo made vigorous and repeated onslaughts on the play: the public was displeased with it - the critics, whatever they wrote, despised it-only the author's high station saved the play from rough treatmentstation saved there were other antagonists also, ${ }^{1}$ and so on. "Bee" soon ended the dispute, such as it was, and the student will be better advised to consult the Revista Española than these papers, for in that review appeared two noteworthy articles on the play, probably two noteworthy articles on the

Turning to the play itself, the reader is plunged as in the Moro Expósito-into the atmosphere of mystery, in spite of being in a modern world. ${ }^{3}$ Don Alvaro, the protagonist, is a hero of unknown origin, reputed to be the descendant of royalty, with Moorish (some say with Inca) blood. He has arrived in Sevilla a short time before the play begins, and is seeking Leonor, the daughter of the Marquis of Calatrava, in marriage.

The father, however, spurns him, and he thereupon plans to carry her off at night, that they may be united secretly. Arriving at her home when all is dark, he is about to escape with

I. See Mesonero Romanos in Semanario Pintoresco, 1842 ,

p. 299. See J. Lomba y Pedraja: "Fígaro como crítico literario," in La Lectura, 1920

3. "Los trajes son los que se usaban a mediados del siglo pasado" we read in the stage directions. But the play is in no way dependent for its effect upon temporal considerations and but little upon local colour. 
her, when the Marquis, who has been forewarned, surprises them, and Don Alvaro, drawing a pistol, unwittingly kills him.

The unhappy lover flees, escapes into Italy, joins the Spanish army which is fighting there, and under an assumed name performs deeds of great valour. While still in Italy, he saves the life of Don Carlos, the Marquis of Calatrava's elder son; he himself, shortly afterwards, is wounded, and Don Carlos, tending him, discovers his identity, challenges him, on his recovery, to a duel-and is slain.

Meanwhile Leonor, after spending a year with an aunt at Córdoba, decides to embrace the most austere form of the religious life possible to her. Accordingly, she visits a monastery near Hornachuelos, (between Sevilla and Córdoba) and obtains permission to live as a hermit near by, taking the place of a holy man who has recently died there. As chance will have it, Don Alvaro, too, has decided to enter religion, and he chooses this very monastery of Hornachuelos, where he quickly becomes known as a monk of great character and devotion.

But thither, after four years, comes the Marquis' younger son, Don Alfonso, who has made it his first care to avenge his father, and has at length tracked Don Alvaro to the monastery. He fails at first to induce Don Alvaro to fight : only after insulting and striking him does he succeed. The two men retire to a lonely spot near the monastery; the duel takes place; and Don Alvaro inflicts upon his foe a mortal wound. Knowing of the hermit who lives near, he cries out loudly, that Don Alfonso may not die unconfessed. To his horror and dismay there appears Doña Leonor ; and Don Alfonso, drawing from her presence the inevitable but erroneous conclusion, summons his remaining strength and strikes his sister mortally with one last blow. Don Alvaro, in utter despair, throws himself into the abyss below the hermit's cave, and is dashed to pieces.

In all the matters that were in debate between the opposing schools, Don Alvaro cut clean across classical tradition. It might have been written by a pupil of Victor Hugo no less skilled in dramaturgy than the master. Its coincidences, surprises, antitheses, strokes of dialogue, and scenes of pure melodrama are as characteristic in their way as the marks which it bears of a more reasoned Romanticism-local colour, the mingling of verse and prose, juxtaposition of humour and tragedy and complete contempt of the unities of time and place. It sinks at times perilously near the ridiculous, as Hugo's plays often did, but with equal certainty it mounts to a point near the sublime.

Azorin, the well-known essayist, has endeavoured to lay bare the absurdities of Don Alvaro, and show to what an extent Rivas imposed upon the credulity of his public. ${ }^{1}$ But to the thinking of many, he has hopelessly exaggerated. what was undoubtedly a good case, and by searching for alleged flaws of construction and inconsistencies which escape the ordinary reader or spectator, only prejudices us against his more legitimate charges. Still even an expurgated catalogue of coincidences and improbabilities is formidable enough.

The surprising of the lovers by the Marquis is due to the habitual presence of a Canon of Sevilla

I. See his Rivas y Larra, Madrid, I916, pp. 25-124, passim. 
at a gathering of common people-a coincidence at least, and perhaps an improbability. Leonor's remaining concealed in such a place as Córdoba and in such circumstances is unlikely; that she should have forced herself to become a hermit and not a nun is even more so; and that her death should have been described as a known fact is absurd, for undoubtedly it would have excited tremendous interest and all the city would have come to the funeral! The means by which Don Carlos discovers his rescuer's identity may be considered highly unnatural, and the psychology of the convalescence scenes is weak. It is unlikely, again, that Don Alfonso should track down Don Álvaro so successfully, and that the latter should take him at the end to the hermit, instead of to the convent near at hand. Some of these traits can be defended, and well defended. Others are more open to criticism. Of the unlikely accidents and coincidences, however, two are more important to the play than all the rest. The first is that accident in the pistol scene upon which the whole plot turns; it is never convincing to the reason, though stagecraft can palm it off naturally enough on the spectator. The second is the amazing chance, responsible for the catastrophe, that not only should Don Alfonso hunt out Don Álvaro, but that, from all the monasteries in the world, the latter should unknowingly have picked out for his retreat that very one near which Doña Leonor was in hiding!

Yet drama has always admitted the element of chance, which proverbially is more frequent in reality than in fiction, and, were these two chief " accidents" unattended by many others, no critic (no countryman, at least, of
Shakespeare) would dream of objecting to them.

It is a pleasanter and more profitable task to consider the power and appeal of Don Alvaro than its defects, if defects they are. It is than its defects, if defects they are. It is frequently asserted that only its melodramatic moments col frequents the theatre; but such an assertion is superficial. Melodrama there is, and Rivas seems to have contemplated the effectiveness of certain skilfully worked up situations, which, indeed, no spectator is likely to forget. There is the pistol scene :

Don Alvaro: ¡Ay de vuestros criados si se mueven! Vos sólo tenéis derecho para atravesarme el corazón.

arqués: Tú morir a manos de un caballero? No; morirás arques :
a las del verdugo. 1

The discovery of Don Alvaro that Don Carlos knows his identity :

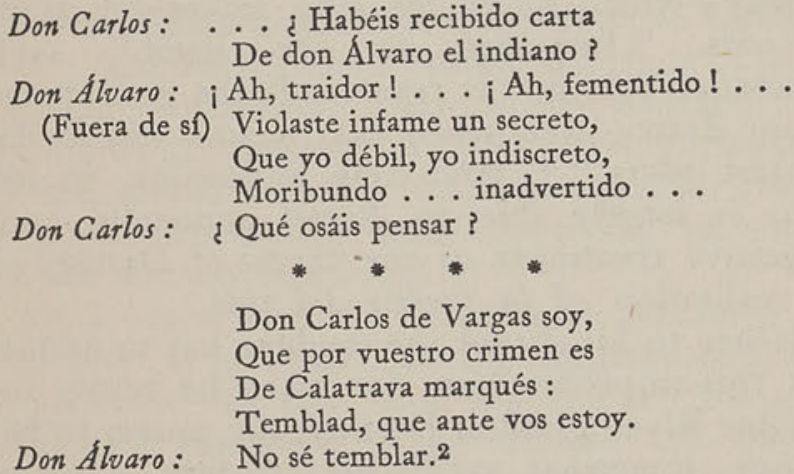

The appearance of Leonor in hermit's garb.: Don Alfonso (como queriéndose incorporar) : i Leonor! ... ¿Qué escucho ? i Mi hermana!

I. Don Alvaro, I, viii.

2. Ibid., IV, i. 
And the final scene of all-a catastrophe full of power on the stage, though weak enough as one reads it :

Don Alvaro: . . . Yo soy un enviado del infierno, soy el demonio exterminador . . . Huid, miserables. Todos : i Jesús, Jesús !

Don Alvaro: Infierno, abre tu boca y trágame. Húndase el cielo, perezca la raza humana; exterminio, destrucción... (Sube a lo más alto del monte y se precipita).

El Padre Guardián y los frailes (aterrados y en actitudes diversas)

¡ Misericordia, Señor! ¡ Misericordia!1

But the true appeal of Don Alvaro has little relation with such scenes as these. Not even does it rest on the author's audacities; its explanation is rather in the Spanish colour of the play, its facile and eloquent versification and the positive dramatic ideals which it embodied. It lives, and will live, for these causes-and for another and more important one also. For its greatest strength is the sense of power-of tragedy-which never for long leaves one as it proceeds. "Immense as life itself," said Menéndez Pelayo, "it transcends the limitations of our drama even when that drama was in its greatest glory." 3 And this impression, in its turn, is largely due to Rivas' successful and suggestive treatment of the theme of Destinyhis realisation of la fuerza del sino.

Rather to his shame the student has to admit that this impresses him, for when he comes to examine Rivas' goddess Destiny, she proves to be a puny, somewhat vacillating creature, a mere shadow of the deity whom she supplants. Very different is she from the 'A tragedy, with whom some critics have compared

I. Ibid., $\mathrm{V}, \mathrm{x} . \quad$ 2. Ibid., $\mathrm{V}$, xi.

3. See his additions to Nuestro Siglo, p. 293. her. She has deceived us moderns, with our poor suburban minds and superficial emotions, into mistaking her for her betters, and her creator, who suspected and hoped that she would, is laughing at us. Ever since his own day the critics have been disputing what she is and does. Some say she is no Destiny at all, but that Rivas wished to exalt the ways of Providence-who punished a true lover thus terribly for his intended elopement! A strange conception, this! Others, rejecting this view, accept the sino, and conjecture what its intentions are-they certainly are anything but clear. Does it aim at Don Álvaro's death? Or at preserving him from death ? Or at sparing him in combat? Or at making him (for some unexplained reason) the murderer of the house of Calatrava? Or at forbidding him peace of mind? To none of these questions is the affirmative answer satisfactory. The best reply is perhaps an indirect one: that Rivas, whose works, like those of most Spanish Romantics, were never distinguished by depth of thought, gave very little attention to the matter at all. His object was to create a certain atmosphere and impression, in which he was signally successful.

Of a piece with the impression produced by the play as a whole, is the impression made by its hero. In one sense the two are complementary: the force of the Destiny with which the hero strives is the greater because its adversary is himself so great. Never was a drama more justly named after its protagonist. He has most, if not all of the qualities with which a hero of tragedy might be endowed, and, were the psychology of Rivas' chief creation as skilful as its spectacular effect, it is perhaps not too much to say that he 
would be one of the greatest of all figures in modern drama.

See how from the very rise of the curtain the spectator's curiosity is awakened concerning the mysterious stranger. Round the Triana bridge on this July evening is a characteristic little knot of idlers-old Tío Paco in his shirt-sleeves, dispensing agua de Tomares, an officer " taking the waters," Preciosilla with her guitar, offering to tell his fortune, men and women sitting round, others passing to and fro-all, like good Sevillans, at leisure. 1 The conversation turns on the bull-fight of the day before, and passes thence to "Don Álvaro el indiano," who "on horse or on foot is the best fighter in all Spain." Suddenly, with the mention of that name, the enthusiasm of the little group takes fire. "Don Alvaro is worthy to marry an empress!" says one. "How gallant he is, how generous!" cries another. "He never comes here to drink without putting down a peseta!" "His very manners declare him to be a gentleman!'

Nor are the nobler qualities lacking in him. The gossips recall a night when seven of Sevilla's strongest bravos attacked him and he vanquished them all. And the officer adds from his own reminiscences the memory of a duel, in which Don Âlvaro bore himself as a very gallant gentleman.

But the most attractive of his attributes is to come, and as the voices hush to a whisper our excitement rises in rapid crescendo. Not only is Don Âlvaro noble and good, but he is a " most mysterious person" of whom so many and such wonderful things are asserted night

I. Don Álvaro, I, i. after night at this very spot that no one knows which, if any, is truth. First, he is a pirate; then, an Inca; then, the bastard son of a grandee of Spain and a Moorish queen. Imagination and conjecture run riot; nothing is certain save his arrival two months earlier from the Indies, laden with mysterious wealth. The situation laden with mysterious wealth.
is full of possibilities. . . 1

Then, suddenly, we discover that while we have tarried, it has been growing dark. There is a sudden hush, and, as the little group round the aguaducho fades from our sight, the protagonist passes slowly across the stage, and goes, without a word being spoken, to meet his destiny :-

\section{SCENE III}

Night falls, and the stage grows dark. Don Alvaro enters, mufled in a silken cloak, and wearing a large white bat, boots and spurs. He crosses the stage, looking about bim on all sides with dignity and melancholy. Then be passes over the bridge and disappears. All watch bim in complete silence.

To the reader it may sound weak enough but on the stage the impression is unmistakeable. And it is an open question if Don Álvaro ever loses his hold upon the average spectator from that first entry until the terrible moment when he leaps into destruction. Some, indeed, may feel that in the pistol scene he forfeits all respect, and that the Marquis' scornful words have hit the mark: $:^{2}$ that psychological truth has been sacrificed to cheap dramatic effect. Others may resent the author's determination to force the

I. Ibid., I, ii.

2. "Tu actitud suplicante manifiesta lo bajo de tu condición." (I, viii). 
"superman" in his hero to the foreground ${ }^{1}$ as savouring of artificiality, while few will defend the convalescence and quarrel scenes throughout. But many also-perhaps the majority of spectators -will seem to be gazing all the time at the Don Alvaro of the opening act. And they will detect no incongruity in the Satanism of the catastrophe, in those scenes where the hero gathers his forces to create the greatest impression of all :-

Os arrancará la lengua

Que mi clara estirpe insulta.

Vamos.

Hora es de muerte, de muerte,

El infierno me confunda. ${ }^{2}$

For such spectators as these Don Alvaro was assuredly written.

When all has been said in disrespect of him, Don Alvaro is a great creation. How can there but be contradictions in one who is " bull-fighter, foreigner, prince, mulatto, grenadier, captain, manslayer, duellist, monk, exterminating angel and suicide." 3 It is impossible to take such a character seriously, as a study in human nature. He was created to be a superman-a mysterya contradiction in terms. $\mathrm{He}$ is all that, and more. For strange as it may seem, there are moments in the play when he is a man, and the frailest and most mortal of all.

I. E.g., in the soliloquy of III, iii.

2. Don Alvaro, $\mathrm{V}$, vi.

3. Funes, op. cit., p. 66. Cf. also Alvarez Espino, op. cit., p. 325

\section{CHAPTER III}

\section{A Romantic Made and Lost}

Whatever be the precise definition which we apply to Spanish Romanticism, it cannot but include the two chefs d'oeuvre of $1834-5$ as foremost among the productions of that movement. But about much that Rivas wrote after his return to Spain there has been considerable discussion, and very little agreement, Undoubtedly Rivas' evolution as a Romantic was, in the beginning, slow, - then came to sudden and glorious fulness. Undoubtedly, too, once Don Alvaro had been staged, his work altered greatly in manner, and much of it was, from the Romantic standpoint at any rate, an anti-climax. Beyond such a general statement as this, opinions will vary, and the sketch here attempted of the evolution and partial decline of Romanticism in Rivas' work can only represent an individual view.

From the publishers' preface to the Moro Expósito it would appear that Rivas had the poorest opinion of all he had written before it. "Of the author's considerable gifts," runs the preface, "scarcely a trace can be found in the two volumes of poetry which he published in I820 at Madrid; and he has several times repeated to us that he would like to collect all the copies of this edition and commit them 
to the flames." 1 Such an attitude, even though reported at second-hand by an interested party, suggests that Rivas completely changed his front about I834, and lends weight to the views of those who represent him as owing his greatness to Malta and John Hookham Frere.

This is a common enough view, and an extremely attractive one, not only to an Englishman, but to anyone with Rivas' own taste for the picturesque and dramatic. It depicts a literary Saul of Tarsus-a youth brought up in the straitest sect of the Classicists, potentially a liberal in literature as he was actually in politics, but neither knowing nor imagining the glories of Romanticism, of which he was afterwards to become the chief apostle in Spain. This ardent young poet, enslaved by unworthy ideals, finds his conversion and salvation in exile. Driven from his country, he settles in a lonely island, where he becomes acquainted with the enlightened Frere, and learns of the new forces at work in literature. $\mathrm{He}$ is instructed by Frere in the works of the great modern Romantics: nay, more, he is " initiated " by him (attractive word !) into the glories of Spanish literature itself, of which, we are invited to believe, he was ignorant. When his "initiation," or "education," is complete, he determines himself to write a masterpiece, and to offer it, as a mark of gratitude, to his new-found friend. This, according to the "initiatory" view, is the genesis of the Moro Expósito, which, since it owes to Frere its

I. It may be noted that together with the Moro Expósito were published (in the Paris edition of 1834) Florinda (see p. 40 below), and some poems and romances which presumably represented the author's own idea of his best work. origin and nature, is dedicated to Frere with true convert's zeal. Hence proceeds that warm and affectionate tribute which is prefixed (in English) to the poem:

$$
\begin{aligned}
& \text { To the Right Hon. } \\
& \text { JoHN H. Frere, }
\end{aligned}
$$

My Dear Sir,

I hope I am not guilty of presumption when I beg dedicate (sic) the following pages to you. That they are hardly entitled to appear under the sanction of a name so deservedly high in the annals of literary criticism, I fully know; yet I cannot help thinking that-poor as the tribute is which I here pay to youit will be kindly accepted; not only because of your constant partiality to the author, but likewise because you have pointed out, and led me into, the path in which I have entered, I am afraid, with more boldness than success.

Your friendship has cheered me in the glomiest $(\text { sic })^{1}$ days of my exile. Your extensive knowledge and excellent literary taste has made that friendship no less useful than it was pleasing to me. Your love of my own dear country has been combined, in my case, with the feelings of concern in my misfortunes and interest for my improvement, which I am proud of having excited in you, and the effects of which I have felt and do still feel. In you the counterpart of the observation of Tacitus may be exemplified: If it is natural in men to bate those whom they bave injured, it is no less natural for them to love those whom they bave benefited.

I fear, I repeat, that I have not profited by your benefits as I ought-certainly not to the full extent of my wishes. Yet, whatever improvement there is in my poetical taste, it is owing to you, and will, I am sure, meet with your approbation and to you, and will, $I$ am sure, me encouragement. At the same tine, however, that I claim, and rely upon your benigity, 1 in passing sentence upon my faults, you will contribute to my cuture ancher qualified than you are: with your well known classical crudition and acquaintance with the principles and beaties of genera poetry, you combine a very remarkable and intimate knowledge of the language and literature of Spain-such, indeed, as few Spaniards can boast. And, as it usually happens, you are not
only deeply skilled in, but likewise partially fond of our Castilian

I. The error is corrected in later editions. 
legendary lore. From all those circumstances, you are no less the natural judge than patron of my Castilian foundling. I commit him therefore to your care, and beg to avail myself of this opportunity to put you in mind of the feelings of gratitude and esteem and warm affection, with which I remain,

$$
\text { My dear Sir, }
$$

Your obliged and obedient servant,

Paris, I December, 1833 .

Angel de SaAvedra.

There are strong statements here indeed, and it may be that Rivas himself, as he looked back in 1833 upon his history, saw it in something like the aspect which has just been represented. "You have pointed out, and led me into the path which I have entered," he says, and "Whatever improvement there is in my poetical taste, it is owing to you." There is no possibility of mistaking Rivas' meaning. He might not have been willing to use the word "Romantic" of his poem, ${ }^{1}$ but he attributed its best and most characteristic qualities (which others, both before him and since, would have termed Romantic) to the influence and instruction of Frere.

Yet the utterances of a convert upon the worthlessness of his past life are proverbially exaggerated, and we need not hesitate to look critically upon a writer who would have burnt all he had written before reaching the age of thirty. It is no surprise, therefore, to find in the poems of Rivas' unregenerate days :

Some sparks of better hope, which elder years May happily bring forth.

A somewhat radical judgment might make him,

I. See III, xxxi. " $\mathrm{Ha}$ declarado el autor su intento al componer el siguiente poema. No ha pretendido hacerlo clásico ni romántico, divisiones arbitrarias en cuya existencia no cree." and with a show of reason, a Romantic in all essentials before ever he came to Malta. At the mo discover that the leaven of pre-Romanticism had long been at work within him, and that he was strongly disposed to receive Romantic influences, at about the time of his first emigration.

Let the sceptical reader examine the juvenilia. He will find that, in Rivas' earliest known verses, written at the age of fifteen, the young author is looking back to mediæval Spain ${ }^{1}$; that in his is looking back to mediæval Spain ; that in his there are touches of personal feeling; that in the collections of conventional compliments which pass as poems of affection it is possible to trace a real and human love-story. And in all these poems are unmistakeable signs of several qualities which the future Duque de Rivas was to make his own : the use of images of light and darkness, an amazing sensibility to effects of colour, and an incipient tendency towards regionalism.

While still at Cádiz Saavedra wrote a longer verse romance than any he had yet attempted: El Paso Honroso $(1812)^{2}$. Spanish critics have praised and abused the poem by turns; it unquestionably shows no great constructive skill, and, as one would expect, is in parts both crude and conventional. The hero is a valiant knight who with nine stalwart companions does battle in the lists against all comers to satisfy the ardour of his disdainful lady, Doña Luz. An unfortunate theme for a young poet, for it leads to tediously narrated exits and entrances and long circumstantial descriptions of each knight or each

I. I, $183-5$.

2. I, 399-482. 
encounter. Yet when we reflect that El Paso Honroso was written on active service, or during convalescence, at a time of national crisis, we are less inclined to wonder at its immaturities, and its indebtedness to Pineda and Espinosa, than to observe the same marks of distinction as are in the lyrics, and ask ourselves how great an advance the next long poem will show. This is Florinda $(1824-6)^{1}$ a poem of which Rivas at one time thought little, but later included in collected editions of his choosing. Taking the reader back more than eleven hundred years to the legendary epoch of Spanish history, he unfolds a drama based on the eminently Romantic themes of love, religion and patriotism, and unfolds it with considerable skill. Classical commonplaces, frigid rhetoric, meaningless epithets, conventional colouring have all but disappeared. The plot ascends to a well-judged climax, and our interest in it is as unmistakeable as in the characters, who are no longer gailydressed puppets, but human beings, of real and human appeal. To these characteristics of Florinda must be added its wealth of description, its considerably developed imagery, its use of the supernatural, and its advance over El Paso Honroso in metrical technique. The new and important elements of horror and mystery, so highly developed in the Moro Expósito, are for the first time introduced by Rivas here. Both his strength and his weakness are discernible in passages like the following, which it is not difficult to attribute to the hand that later penned the narrative of the unveiling of the seven heads :-

I. II, $363-486$.
Don Julián, con ojos centellantes,

Del regio pabellón ve la ruina,

Y sus muertas cenizas humeantes

Angustioso revuelve y examina.

Entre cuerpos ha poco palpitantes,

$\mathrm{Y}$ entre espantables bultos, imagina

Ver el cadáver de una hermosa dama,

Cuya cabeza consumió la llama.

Pásmasele la sangre, y confundido,

Sus miembros el sudor inunda helado

Yus miembros cl sude funun helado;

Y tiembla, y pierde fuerzas y sentido

Yunque a saber no acierta quién ha sido

Aquel cuerpo infeliz medio quemado,

Y gimiendo sobre él se precipita. ${ }^{2}$

If there is much of this sort that is ineffective in the poem, too great a love for " horrid shrieks," cold sweat, hair standing on end, and eyes starting from their sockets, let it be remembered that this was a first essay in the horrible, and belongs to the early nineteenth century.

Meanwhile, Saavedra in his exile was making equally rapid strides towards Romanticism in lyric poetry. True, his bitter experiences, while prompting some few sincere and unaffected subjective poems, in no way prevented him from penning intolerable odes reminiscent of the excesses of the century that had passed. Even as late as 1832 , and in Paris, he could write a poem "To my son Gonzalo, aged five months," which it would be painful to quote. ${ }^{2}$ And we may hope that Frere never saw the stately ode which was sent from Malta in 1829 to a certain aristocratic bridal pair in Madrid, and began :-

No sonará mi acento

En el nupcial festín i Ay! No me es dado

I. Florinda, Canto V, ${ }_{5}^{\mathrm{I}-2}$.

2. II, II7-I20. 
Del insigne Mirisco al dulce lado

Su cítara pulsar encantadora,

$\mathrm{Y}$ enriquecer el viento

Con altos versos y con voz sonora ....'

Frere's interest in his pupil's "improvement" would have suffered a shock had he known of those out-of-school verses. And there were others like them. .

The critic will prefer to study El Desterrado ${ }^{2}$, a poem of exile, in which the poignancy of suffering mingles with patriotic ardour; Cristóbal Colón, ${ }^{3}$ where in a calmer mood the poet works with a mind freed from convention; the Sueño del Proscripto, 4 written in London amid the " hideous foos of the cold Thames"; and best of all the well-known poem on the lighthouse, El Faro de Malta (1828). ${ }^{5}$ In this, as in some of his lyrics which were written before he ever knew Frere, the commonplace and artificial are practically non-existent. The pen-pictures are firmly and clearly outlined; the rhetorical figures are vivid and appealing; and the narrative, in which the poet describes his first sight of the lighthouse on his journey from Italy, is once more striking in its sincerity and passion. But the most admirable trait in the poem is its abrupt and magnificently unexpected conclusion : it seems about to conclude with a panegyric of Malta, when suddenly, with no elaborate justificatory device, the theme changes, and the poem ends where its author's heart is fixed-on the city of his birth :-

$$
\begin{aligned}
& \text { Viéronla como yo los marineros, } \\
& \text { Y olvidando los votos y plegarias } \\
& \text { Que en las sordas tinieblas se perdian, }
\end{aligned}
$$

$\begin{array}{llll} & & \text { 2. II, } 4 \mathrm{I}-57 . & \text { 3. II, } 6 \mathrm{I}-2 .\end{array}$

$\mathrm{Y}$ fuiste a nuestros ojos la aureol

Que orna la frente de la santa imagen,

En quien busca afanoso peregrino

La salud y el consuelo.

Jamás te olvidaré, jamás ... Tan sólo

Trocara tu esplendor, sin olvidarlo,

Rey de la noche, y de tu excelsa lumbre

La benéfica llama,

Por la llama y los fúlgidos destellos

Que lanza, reflejando al sol naciente,

El Arcángel dorado que corona

De Córdoba la torre. ${ }^{1}$

Enough has probably been written to show that Rivas' Romanticism was a growth, and not the result of a conversion, that his own literary sense was his "initiator," not John Hookham Frere. It is true that the body of exile lyrics shows a less marked advance on the earlier poems than might have been expected classical metres yield but slowly, conventionalities persist, and mythological deities are not entirely banished. But there is very little in the Moro Expósito which cannot be found in germ in the poems of 1806 to $I 830$.

Frere nursed and tended the young plant till it had reached such vast proportions that its earlier existence was forgotten. He inspired him with such great ideals that as the exile looked back upon his earlier work it seemed to him that Frere had "led him into the path" which he had entered. In the Englishman's Spanish library he was allowed to revel, and delighted to deepen the acquaintance which he already had with the treasuries of chronicle, ballad and

\footnotetext{
I. II, 73-4.
} 
romance. But more than this Frere was able to do for his protégé. He opened to him the protege. He opened to him the store-house of English literature ; Byron attracted him; Shakespeare and Scott became his intimate companions; and, as will presently be seen, he made part of the work of each of these his own.

Here then, in brief outline, are the various to Moro Expósito. It steps which lessible, to trace would be interesting, were it possible, to trace a similar evolution in the dramas written before Don Alvaro, but facts point rather here to sudden conversion and inspiration, unless, as is sudden converess of developunlikely, several stages in the process of development are hidden from us. The only plays of Rivas', however, to which reference cannot be Rivas, how extremely early, before he was twenty-five. Ataulfo was neither played nor wrinted, while of Doña Blanca some notes remain print unpublished manuscript was lost. Investigations must, therefore, begin with the three earliest plays extant, which show few signs of grace, being in fact merely adaptations. Aliatar (1816) is litle mon a boyish essay in drama. The Duque de Aquitania (1817) is based on Alfieri's Oreste, which had been performed in Madrid ten years earlier; and it follows Alfier as closely as Malék-Adbél (1818) follows as closely as Malek-Abilde. Saavedra is quite Mme. we frank about "This tragedy," he says in his preface, "less so. "This is "is more Mme. Cottin's the the argument, hers are the situations, hers the

Its date is generally given as 1815 ; it was published, I. Its date itle-page the only edition, which is very rare, will show.
Mine are but the dramatic plan, the actual lines, and a few scenes, perhaps the weakest. Finally, if there are beauties in Malék-Adbél they are due to this distinguished French authoress: the defects are all mine."

Textually freer, but still in the bonds of convention, is Lanuza (1823), a declamatory political drama, which has owed its occasional revivals to the accuracy with which it reflected temporarily prevailing radical ideals. Neither plot nor characters have any reality; and the speeches are dull and bombastic, save here and there, when the author, under discreet disguise, is evidently writing of the tyranny of Fernando VII. Arias Gonzalo, written in Malta $(1826-7)^{1}$, and considered unworthy of publication till I894, was judged by Rivas' son to be "the best of the Duke's tragedies."2 But it is hard to find comfort in that phrase, or indeed to commend the play at all, except by comparison with its predecessors. It betrays a looseness of thought and an indifference to questions of form, combined nevertheless with an extreme reluctance to break with the precepts of pseudoclassicism, most noticeable in the retention of the unities. It seems to look forward rather than backward-that is all one can say in its praise. In the hero, Arias Gonzalo, we have not only a man of flesh and blood-a real human being-but a character distinctly resembling the orthodox Romantic type. In this connexion the reader may remark some interesting premonitions

I. Rivas himself (edition of 1854 ) dates it 1826 . Others, including the editor of the 1894 edition, place it later; they including the editor of the
vary between 1827 and 1828 .

2. I, xi. 
of both the Moro Expósito and Don Alvaro. ${ }^{1}$ In 1827 Rivas wrote a comedy entitled $T$ anto vales cuanto tienes, his last play before Don Alvaro. The juxtaposition of the two in the latest edition of his works recalls this; and the fact is amazing, for the earlier play is a farcical Moratinian comedy, as unlike as possible to the latter. It is quite undistinguished, commonplace to a degree, and not always even amusing. The parts of the play which, as sometimes they do, provoke hearty laughter, depend for their effect, not upon character but upon situation. It seems impossible that the play could have been conceived, much less written, in Malta, but significantly it was not published till $\mathrm{r} 840$, when its author's fame was secure.

The process, then, by which Rivas came to write Don Alvaro has yet to be explained. Probably the change in his ideas of drama came from France, and the inspiration to write this play from the thought of rivalling Victor Hugo in his chosen field. Such a view is supported by a conversation between Rivas and his friend and fellow-exile, Alcalá Galiano, related as follows by the latter :-

"Saavedra and I were abroad at the time of the great vogue of Romanticism, and D. Angel conceived the idea of writing a drama on the Romantic model.

"' Nothing easier!' I said to him, 'You have only to recall some of the tales which you must

I. See, for example, Arias Gonzalo, Act II, Scene iv :$Y$ huye de mí la muerte, porque niegan Todo descanso a mi penar los cielos * * * *

Dejadme ir a buscar la ansiada muerte. have heard as a child in Córdoba ; any one of them will do for a drama." "

"Saavedra outlined first one story, then another, then a third, in which figured an indiano.

"' That will do,' I cried, 'Say no more. Well staged, that story will be tremendously effective. Let us get to work." ",1

So the drama, thus nonchalantly conceived, was written, with the idea of its being played in Paris. Alcalá Galiano (some say Prosper Mérimée) translated it into French. Then the amnesty came, the exiles returned to Spain, and Rivas, in the anxiety and bereavement which followed, forgot his drama. It is even said that he burnt it. Only one day when it was recalled by some friends, did the idea of rewriting the play in Spanish take hold of him. The task was performed quickly, and before many weeks had passed the complete drama was read to the same group of friends, preparatory to its production. It was then that Gallego rose to his feet and said: "Gentlemen, this drama is the work of a great poet, but of a poet who is crazy."2

Perhaps Rivas agreed. If he did, one can understand why in later years he took playwriting very lightly, and returned to productions of a more conventional type. As far as Romantic drama went, he was a lost leader. The truth is probably that, though apparently he enjoyed writing plays at his leisure, he was not fitted to be a great dramatist by his natural gifts. He told a story well, but not in five acts. He had a rich and glowing imagination, but it excelled in

I. Funes, op. cit., pp. 63-4, note.

2. Cited by Hidalgo as a note to the relevant entry in his Bibliography, Vol. II, p. 335 . 


\section{RIVAS AND ROMANTICISM IN SPAIN}

pictorial, rather than dramatic effect. His power of characterisation and his psychology in general were always weak; and though he could group his figures well enough in the most effective tableaux he found it hard to arrange their adventures in the form of a play. Hence, when he was firmly established on his pedestal both in literature and in society, he followed in drama the line of least resistance. He wrote no plays to be reckoned with after the age of fifty, and, of all those he ever wrote, only El Desengaño en un Sueño is worthy to be compared with Don Alvaro either in intrinsic merit or as an example of Romantic drama.

Nor was Rivas' true genius in the lyric. Taken as a whole, his later lyrical poems are a poor collection. He never entirely ceased to produce florid and conventional odes, and the artificialities of the autograph album. Further, so great was his facility for versifying that he sometimes wrote letters in verse. And his relatives, instead of giving lines like these decent interment included them ${ }^{1}$ in the posthumous edition which is now chiefly read:

Y llevo siempre bollos de manteca, Un pâté de foie gras, Jerez, Champaña, Jamón, pavo trufado y fruta seca...2

Even if such verses are magnanimously discounted, odes like that to Seville Cathedral have still to be read, together with much uninspired verse

r. Some of these verses had a particular biographical interest, it is true (see II, 295, n.), but Rivas himself had set the example it is true (see II, 295, n.), but Ring in his collection El Crepuisculo de la Tarde (185 I) by including in his collection works the Epistle of over 500 lines and in the 1854 edition of his works the epistle which is almost from which the

2. II, 3 I 8 .

\section{A ROMANTIC MADE AND LOST}

dated from Naples, by those who would capture the few spontaneous passages which appear among the later poems, only to vanish as suddenly as they come.

The one clear lesson, then, of Rivas' last thirty years' output is that his genius was essentially that of the narrative poet. In an early narrative poem he showed first of all that he was throwing off the pseudo-classical shackles. In the first and longest of his leyendas, ${ }^{1}$ he established himself as a leading Romantic. In his late narrative poems, the Romances Históricos and Leyendas, he proved that he was still, in spite of all, a Romantic at heart.

The evolution of Rivas' true genius may even be traced as follows ; first, the early Romanticism, timidly and feebly expressed, of the Paso Honroso and Florinda; then the full-flowering Romanticism, yet undeclared as such, of the Moro Expósito; with it the Romanticism whichto change the figure-blazed forth and flashed fire in Don Alvaro, to smoulder once and again in a later drama, and finally to burn with a renewed and steady light in the Romances Históricos and Leyendas.

Only a detailed study of these latter books could serve to expound this view as it deserves, but what has already been written will make it the more explicable. No one can ever understand Spanish Romanticism who persists in regarding Don Alvaro as its most characteristic production, while to think of it as Rivas' masterpiece is to throw his other works into a false perspective. Typically Spanish it may be in

I. For he describes the Moro Expósito in its sub-title as a "leyenda en doce romances" 


\section{RIVAS AND ROMANTICISM IN SPAIN}

its setting, local colour, versification and reminiscences of the Golden Age; but it is typically exotic in its conception of the hero, in plot and situation, in its violent contrasts and melodramatic poses. And these are the more noticeable, as no doubt they were meant to be. But the Romances and Leyendas, as will be seen, are Spanish to the backbone; they date from years when both author and movement were more mature; and though, like Spanish Romanticism itself, they show very clearly the influences of foreign genius, the hall-mark which they bear on their face is that of the genius of Spain.

In themselves, too, they are greater, and this because they are flowers from Rivas' peculiar field. In no genre could he better conceal his natural weaknesses nor display to greater effect the qualities in which he excelled. Plot-construction mattered nothing: he was free to move in a succession of tableaux as suited him best. Richness of colour and description could be made to atone for weakness of characterconception and absence of character-development. All kinds of sidelights could be thrown upon the scenes which it would be difficult, or impossible, to introduce into drama. The very narrative, or any one of its parts, could be lengthened or shortened at will. Digression, reflection, or any other means could be employed to stimulate the interest of the reader. So Rivas, the painter and the story-teller, abandoned himself with a light heart to this favourite Spanish form of literature, and the result was the crown of his Romantic art. In a prologue to the Romances Históricos, he makes it clear that, though he may be a "Romantic lost" to drama, he has only carried
A ROMANTIC MADE AND LOST

the precepts of Romanticism into another genre. Without going so far as to defend every one of its "bold, varied and unequal flights" 1 ne speaks with evident satisfaction of the period of regeneration which Spain has reached, the period " in which poetry, throwing off the cramping shackles of arbitrary rules, respected though they were by an entire century, has flung on one side the servile imitation of Latin and Greek authors, and sought its true inspirations in ages more in harmony with modern societies."2 $\mathrm{He}$ defends the ancient forms and metres of Spain, cites passages to prove their peculiar beauties, and concludes with an appeal to the Romantic poets of his own and future generations :-

"Let us never abandon the rich and abundant treasure of poetic expression which we Spaniards possess in our octosyllabic romances, nor cast aside one of our principal titles to poetic glory."3

A brief survey of the eighteen Romances Historicos which form the collection will show how eminently readable they are: other of their merits will appear later. Patriotic they may be in their main intention, but the author makes no attempt to create a false atmosphere of patriotism by disregarding or palliating Spain's less creditable epochs. On the contrary the narratives of Pedro the Cruel ${ }^{4}$ strike the note of horror, which is not wholly relieved by the long heroic poem on the deeds of Columbus ${ }^{5}$

\section{IV, xiv.}

2. Ibid.

3. IV, xxviii

3. IV, xxviii. 4. Viz. : "Una Antigualla de Sevilla," “El Alcázar de Sevilla,"
"El Fratricidio," IV, 3-63. 5. IV, 89-I II. 


\section{RIVAS AND ROMANTICISM IN SPAIN}

nor by the story of the boyhood of Hernando Cortés. ${ }^{1}$ It recurs again and again: with the spectre of López Vivero which appears before the execution of Alvaro de Luna, ${ }^{2}$ in the revolting scene which converts to religion the monk known as St. Francis Borgia ${ }^{3}$, and, most markedly of all, in the gruesome "Tale of a Veteran "4, in which Rivas' love for the grotesque reaches its highest point-or its lowest.

But all is not graves and worms and epitaphs in these romances. The pure breath of patriotic idealism is never for long absent, and at times it bears all before it. In the little group of narratives which centres round the Battle of Pavía $^{5}$ we seem to be listening to the boy-soldier of 1808 . For once his anti-French bias comes to the front, in his portrayal of the King of France and the Spanish warriors, only to re-appear with redoubled force in the chronologically later narratives of the Napoleonic wars. "Bailén," written in 1839 and inscribed to Castaños, ${ }^{6}$ was poured out at white heat. Hardly characteristic of the collection as a whole, it is noteworthy, not only for its simplicity and evident sincerity, but for its lyrical effectiveness and the skill with which imagination is enlisted in the service of patriotism. "¡ Bailén!” begins the final canto,

$$
\text { i Oh mágico nombre ! }
$$

a Qué español al pronunciarlo

No siente arder en su pech

El volcán del entusiasmo ?

¡Bailén! . . . La más pura gloria

Que ve la historia en sus fastos,

camp

$\begin{array}{llllll}\text { I. IV, } 15 \mathrm{I}-173 . & \text { 2. IV, } 77-8 . & \text { 3. } & \text { IV, } 284-292 . \\ \text { 4. IV, } 35 \mathrm{I}-394 . & \text { 5. IV, I8I ff. } & \text { 6. } & \text { IV, } 395-4 \mathrm{II} .\end{array}$

¡ Bailén !. . . en tus olivares

Tranquilos y solitarios,

En tu arroyo y en tus prados,

Su tribunal inflexible

Puso el Dios tres veces santo,

$Y$ de independencia eterna

Dió a favor de España el fallo.

But Rivas' present-day readers will probably prefer poems more typical of the Romances as a whole, such as " El Fratricidio" or " El Solemne Desengaño." These show all the most marked characteristics of Romanticism in Spain; and in addition they excel in their descriptions and local colour, as well as in the technical art of the story-teller.

The three Leyendas published in 1854 are not unlike these earlier narratives in essentials, though richer in colour, more considerable in length, and somewhat more idealistic in tone. The narrative of the "Miraculous Lily," which comes first in order, ${ }^{2}$ is based on the well-known theme of the constant wife whose faithfulness is called in question, and vindicated only when her husband's terrible revenge has made reparation impossible. Rivas' version of the story elaborates it greatly by introducing the Reconquest of Granada as an opening theme, his hero, Nuño Garcerán, being a Leonese warrior who has taken part in it. The principal elaboration, however, is in the sequel to the tragedy, where the villain-Rodrigo, an old servant, who had acted from the usual motive of tragedy-is killed in a duel, but permitted by God to keep the use of eyes and tongue till he has confessed the truth to Nuño. The opportunity occurs

$$
\text { I. IV, 404. 2. V, 213-320. }
$$


only twenty years after the duel; Nuño falls as one dead upon learning how great has been his crime; and hereupon is imposed the theme of the lily, which is to spring up by a miracle when his penitence is complete, and his soul permitted to wing its way to heaven.

Contrasted with the elaboration of this first legend are the comparatively straightforward narratives "Maldonado"1 and "El Aniversario."2 The first is by far the longer, with its vivid tale of the storm overtaking the Aragonese fleet; the Admiral's pilgrimage to Montserrat to return thanks for deliverance; the insult offered to him by the Duke of Normandy; the challenge and the preparations for the duel (with episodical interludes); finally, the Admiral's victory and insistence upon taking the five lilies from the Duke's shield and nothing more. It is a story skilfully told, psychologically more convincing, yet to the reader less attractive than is the "Miraculous Lily." The earlier poem charms by its wealth of imagination, colour and beauty, and by a happy use of the supernatural. The third poem is perhaps the least meritorious of the collection, though to call it so is only to emphasise the high level of the whole. The story is certainly singular, if not entirely attractive, and shows the strength and weakness of Romanticism as well as anything that Rivas ever wrote. The opening scene in Badajoz, the battle and the final incident have no artistic unity among themselves: the last-named, however, has a certain grandeur which atones for its uncalled-for, and in the circumstances unnatural, gruesomeness. It tells of a priest who determines that Mass shall

$$
\text { I. V, 321-402. 2. } V, 403-426 \text {. }
$$

be celebrated in Badajoz Cathedral even during the civil war, though none attend. To his amazement, when he turns to say the "Dominus vobiscum," the nave is full of the skeletons of the old Christian warriors of other days who rest from their labours in the grave but have been miraculously raised in order to plead the Holy Sacrifice.

Over sixty years of age as he was when he wrote this last of his legends, the Duque de Rivas can in no way be described as a spent force. Indeed, as one of his earliest critics, himself a strong Romantic, declared: "The Duke's imagination is still in its teens; the blood courses still in his veins, and as vigorously as half a century ago; the winter of his life is the most fruitful of springs." 1

Indeed, as we study the legends, we seem to be carried back to the days when the Moro Expósito was in the making, and our attempt at tracing the Duke's literary path has brought us out again, as from a maze, at its entrance. Yet at least we have seen that his Romanticism grew and flourished, though it brought him, not a sustained notoriety, but an enhanced popularity and fame. And if his Romanticism, while in lyric and drama it faded, survived the vogue of the movement itself in the one genre in which he excelled, we owe this to his persistence in that genre, and his willingness to be a "lost leader" in one which was not his true medium of expression.

I. Eugenio de Ochoa in his prologue to the leyendas written for the 1854 edition of Rivas' Works. 
PART II.

RIVAS AND HIS ART. 


\section{CHAPTER IV}

THE POET OF LIGHT AND COLOUR

Throughout his life the Duque de Rivas was devoted to painting. His pencils, even in childhood, attracted him as much as the pen; in exile he found in painting a continual solace and even a means of livelihood; in later years of prosperity, the embassy, ducal palace or country house in which he might be was frequented as often by painters as by poets. And he carried all his enthusiasm into literature. Never, in Spain at least, was there a writer with a more passionate love for colour, or with a better claim to be termed the painter-poet.

Pronounced as is this feature of his work, from its beginning to its end, it has been almost entirely overlooked. It would be an attractive task, did space permit, to follow the growth and increasing skill in his use of colour, and the variety of purposes which it subserves. As it is, a record of some impressions which Rivas' word-paintings make upon us must suffice to commend the subject for further study.

Even in his earliest lyrics young Saavedra is something of a colourist, but he is copying conventional colour-phrases, not creating. He can paint only the "grey clouds," the " purpling east" ; the lady's "snow-white hand" or the "roses and jasmine" of her face; the "white foam " of the sea, and the "green crests" of the groves. With the Paso Honroso, it would seem, 


\section{RIVAS AND ROMANTICISM IN SPAIN}

came the first realisation that the colours of his poems could be as real as the colours of his palette. He had an excellent canvas to copy, and it can hardly be doubted that, for the first time, as he described the knights appearing in the lists, he saw them, as it were, before him. The kings at arms' white colts with their purple coverings lead the way. Following them are the musicians in purple with brightly-coloured plumes. Don Suero and his companions are a study in white and gold, contrasting with the jet-black of their steeds. Of their opponents the proud Abreo appears in red and grey upon a chestnut mount ; Liñán, in "shimmering mail " has all his trappings of green; Lope de Ferrara and his charger alike are vested in gorgeous yellow and black. Doña Leonor appears in mourning weeds but with a snow-white veil; her little page is dressed in gold with scarlet plumes. The picture of Doña Luz is of particular interest, as combining the conventional colouring of pseudo-classicismjasmine and roses, pearly teeth, snowy breastwith vesture of red, white and gold, the description of which suggests some care on the part of the author.

The Paso Honroso, as will be seen, allowed the young painter-poet to daub his colours rather freely on a naturally crowded canvas, with the certainty that a lack of restraint would be remarked (or, at least, objected to) by very few. In Florinda, where he was somewhat hampered by scenes that were by nature drab, the profusion of his colours only accentuates his artificialities. There was little beyond Nature that he could illuminate, and in using this opportunity he seems rather to be painting the lily. One tires of hi " crimson clouds," "red dawn," "cerulean
THE POET OF LIGHT AND COLOUR 6

waves," " distant peaks of blue," " the silver and sapphire of the lofty sphere"; the phrases which bear witness to a true inspiration are few indeed. In the exile lyrics it would seem that he has recognised this-unless, indeed, the cause of their lack of colour is the intensity of the poet's emotions which forbids him his normal art. $\mathrm{Be}$ this as it may, the result is just the same.

In the Moro Expósito Rivas has his first real opportunity to profit by these preliminary attempts and create a great series of pictures. In the result, he shows that, by this time, not only can he be prodigal of colour still where the size of the canvas allows it, but also introduce skilful touches with great effect. From the opening of the poem, where the splendour of Abdimelik's marriage is enhanced by the white and scarlet of a hundred knights, and the adornments of crimson and gold, to the final affray, in which Rui-Velázquez appears in a purple tunic fringed with gold, and a coat of arms of gold, green and scarlet, Rivas loses no chance of conveying effect through colour. So seldom does he strain these effects that for the sake of interest one possibly inartistic and excessively coloured picture may be given, that of the housekeeper waiting upon the guests in the celebrated feast of Canto VI : ${ }^{1}$

... El ama, tan oronda como limpia Con tocas de cendal cual nieve pura, Que las castañas trenzas mal cubrian, Un brial de paño verde, guarnecido De franjas de oro, mangas con prolijas Bordaduras de azul, de rojo y negro, $Y$ aljófares al cuello, $y$ varias cinta Señala a cada huésped puesto y silla.

I. III, $239 \mathrm{ff}$.

\section{I}

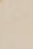

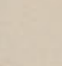




\section{RIVAS AND ROMANTICISM IN SPAIN}

No feature of the colouring in this poem is more striking than the development of its nature passages, especially of sunrises and sunsets. Rivas had little eye for Nature, ${ }^{1}$ except in so far as she is the mistress of all hues, but at Malta he must often have allowed his gaze to rest for long on her daily mysteries, and he consigned his pictures of them to paper, not now in commonplace, unmeaning phrases, as he thought of those Andalucian skies which he could no longer see. His sunsets are no longer creations of a few curt words, but realities, distinct and individual, sometimes less varied and brilliant, sometimes more, but never the same :-

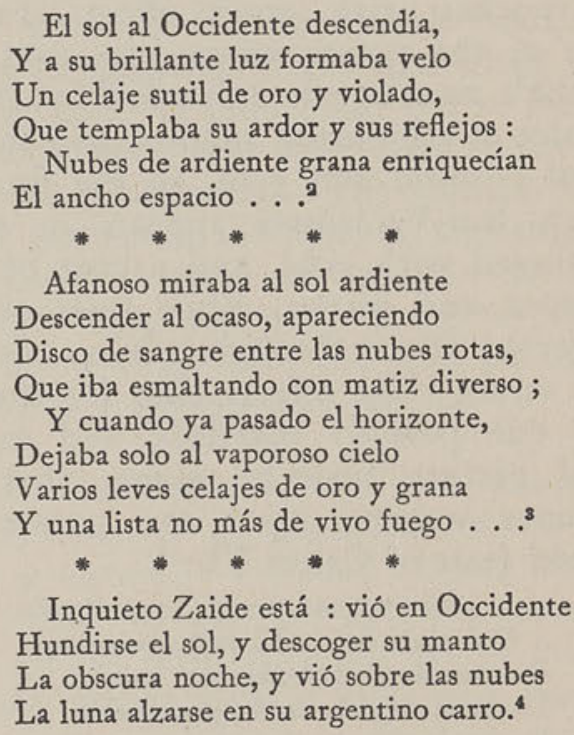

I. This statement we have primarily on the authority of Rivas' brother-in-law, the Marqués de Valmar (see Cueto, Riv. cit. P. $52 \mathrm{I}$ ) and it cannot be said that his poems justify us in entirely controverting it.

2. III, 63. 3. III, 84. 4. III, 95 .
THE POET OF LIGHT AND COLOUR $6_{3}$

And beneath these southern skies are the " eternal palms," the glossy groves of orange-bloom, the more sombre hue of the olive, and the wealth of flowers which adorn in their magnificence the "land blessed of God."

Contrasted with this riot of colour is some typical scenery of Castile: its bare soil, its sullen sky hidden by white clouds, its grim mountain horizon diversified by rugged peaks and boasting no wealth of forest and grove but only sparse clumps of pine-trees (verdinegros pinos). ${ }^{1}$ Such scenes are not peculiar to Castile, it may be said. But they are at least appropriate to it, and among the triumphs of the colouring of this poem are its subordination to the total effect and the continual harmony between colour and sense. The impressiveness of scene after scene is enhanced by a touch surprisingly sure. It is by no accident that as Zaide tells Mudarra the story of his brothers

los siete cipreses que cercaban

El sitio aquel, sus puntas verdinegra

Con lúgubre rumor. ${ }^{2}$

that before Giafar makes his dreadful revelation to Lara he seats him on a cushion of regal purple : that mourning shows should be spread on the occasion of the final conflict ${ }^{3}$; that after RuiVelázquez' castle has been burned to the ground, the morrow's sun should rise in a sea of blood.

Salió el sol entre cárdenos vapores,

Que dieron a su faz color de sangre,

Y pálido y sin brillo, en el espacio,

Cual si una gasa densa lo ofuscase,

Se alzó y siguió su curso
I. III, 223, 11. $\mathrm{I}-8$.
2. III, $163,11.2 I-4$.
3. III, 483,485 .
4. III, 390 , $11.1-5$ 
The lingering pleasure with which the painter dwells on the succeeding colour effects, where the distracted father is pictured against a background of splendour, alone makes the scene one to be remembered. The passage quoted above continues :

\section{A su presencia \\ Si no furor, perdieron las voraces}

Llamas su resplandor, mientras el hum

Cobró aspecto más negro y formidab

Cubriendo con fantásticos colosos
Del cielo azul el empañado esmalte.

Yel cielo azul el empañado esmalte.

Y entre ruinas y escombros se ve'
Aparecer al despechado padre. ${ }^{1}$

Were the relative frequency of each of the colours to be estimated-an unattractive taskblack, green and red would probably be found to occur fairly equally. But over and above them all would surely come white. The silvery splendour of the moon, the frequent and dense white mists, even the clouds of dust upon the plain, are Nature's part of this tribute. Mudarra's snow-white horse, the white robes of priest and monk, the maidens clad in white with crowns of orange-blossom and jasmine, the white cloths which swathe the lances in sign of peace, the white sheepskins which carpet the palace-these are not a tithe of the traits which are so numerous that they meet us wherever we read. Kerima's snowwhite beauty, so continually insisted upon, is as real as pen can make it, not only because it is a trait so unexpected in a Southern maiden, but because her creator is now a master of his art. The bridal scene in particular is one of dazzling splendour. It is set in springtime, on a day when the sun is shedding torrents of light and bathing the city in splendour. Youths in the

x. III, 390, 11. 5-I2. procession, their arms glittering in the sunlight, carry white pennons; nobles and knights bear white emblems, monks wear white albs, and bride and bridegroom the white robes of neophytes, while Kerima is crowned with lilies and white roses. Such are the surroundings in which she takes the resolution henceforward to serve Our Lady, whose flower is virgin-white.

The significance of these arrays of white, as will shortly be seen, is greater than at first may appear.

In the Romances Históricos the artist's canvases have the same brilliancy of colouring. Still we meet crimson and golden sunsets, the reds and purples, whites and golds of kings and their fair ladies, the snowy foreheads and blue eyes, the warriors' "white harness" and showy plumes. But in spite of these brilliant splashes of colour, the dominant tone is neither red, nor blue, nor gold, nor is it white and silver as in the longer poem, but black, with white as occasional contrast. Whole romances occur in which no other colour is seen. In the first narrative alone-that sinister story of a crime of Pedro the Cruel-there is the Negro bulto tendido

De un traspasado cadáver

$\mathrm{Y}$ de pie a su frente un hombre,

Vestido negro ropaje...

the black wings of the Archangel, ${ }^{2}$ the alcalde in his black gown, ${ }^{3}$ the king in his black cloak, ${ }^{4}$ the heavens, which, at nightfall

con negras sombras se enlutan ${ }^{5}$

the alcalde once more in "vestments black" 6 and that dark form (negro bulto) which slips unobserved behind a pillar, to reveal itself later as the King. ${ }^{\text {? }}$

$$
\text { I. IV, 5. 2. IV, 6.. } \quad \text { 3. IV, 8. 4. IV, II. }
$$

5. IV, I2. 6. IV, I2. 7. IV, I4. 


\section{RIVAS AND ROMANTICISM IN SPAIN}

The predominance of black in this poem might perhaps be explained as being in keeping with the sombre character of the story and its principal figure. But in other of the poems there is no such reason for the display of gloom which characterises them very noticeably. To take only one example, "Don Alvaro de Luna" is equally striking in its use of black, with white as contrast. The "great black eyes" of the ventera, ${ }^{1}$ the "black and yellow plume" of Diego Estúniga and the black band on his shield, ${ }^{2}$ Don Alvaro's white cloak with its distinctive red cross, ${ }^{3}$ and his black hood, ${ }^{4}$ give the romance its colour-tone in the first two cantos. And these are almost the only occasions where colour of any kind occurs in the entire poem, if the concluding canto be omitted, where, from its nature, black predominates.

The examples which might be multiplied from the other poems force upon us the conclusion that black, together with white, gives the outstanding colour impression of the Romances Históricos. It may be added, however, that the collection as a whole has far less colour than Rivas" earlier poetry. "Un Embajador Español" has not a trace ; "La Buenaventura ", ${ }^{6}$ in all its six hundred lines, has but a mere dozen; "El Solemne Desengaño," also, among the longer of the poems, has scarcely more; while the eleven hundred lines of the "Cuento de un Veterano"s have but one reference, and that a conventional one, to any colour other than black and white.

$$
\begin{aligned}
& \text { I IV, 67. 2. IV, 70. } \quad \text { 3. IV, 7I. } \\
& \text { 4. Ibid. 5. IV, 143-I50. 6. IV, } \mathrm{I}_{5} \mathrm{I}-\mathrm{I} 73 \text {. }
\end{aligned}
$$

THE POET OF LIGHT AND COLOUR

It should be noted, in partial-perhaps in complete-explanation of this comparative weakening of colour-appeal, that the rapid octosyllabic line which Rivas uses in the collection referred to, and defends so warmly, is essentially a narrative metre, and far less suited to the introduction of descriptive passages than are the longer lines of the volumes which preceded and followed it. In the Leyendas Rivas is far more prodigal of description, and displays a very feast of colour.

No one tint can be fairly said here to predominate over another. All seem to recur continually. A passage like the following, from the canto which opens the story of the Miraculous Lily, may be taken as typical :

$$
\mathrm{El} \text { sol desde el oriente, }
$$

Al perfilar de grana y de topacio

Celajes que bordó la blanca aurora

$\mathrm{Y}$ al ocupar el trono refulgente

Del zenit en la cumbre del espacio,

Derramando a raudales

Vida, riqueza y luz a los mortales;

$\mathrm{Y}$ al declinar, tras nube que tras flora

De morado y de jalde, al occidente,

Saluda los católicos pendones..

All Nature is decked in the most glorious colours for the drama of the Miraculous Lily. Seas of emerald sparkle in the sunlight; clouds of scarlet and crimson curtain the dawn; sunset after sunset is painted in vivid but varied hues; orange groves of glossy green with scarlet and goldenplumed birds lend a tropical brilliance to the story; while the white doe and the white lily give it its predominant tone. ${ }^{2}$ Nuño travels

$$
\text { I. } \mathrm{V}, 228 .
$$

2. Among the many examples that might be cited we refer readers to V, 293, 11. I-12, V, 322-3, V, 308, 11. 5-10, V, 239. 
northward from Granada, and when he approaches his mountain-home it is the hour of "rosy dawn," the hour when the "golden gates are flung wide for the sovereign sun." And how, at such a moment, does Nuño see his native mountains?

Vió Nuño aparecer azul un monte

Aún de nieve vestido,

Allá en el horizonte,

$Y$ dióle el corazón hondo latido.

La sierra es de León . . . 1

In "Maldonado," to take but a single other example, there is a tournament which recalls to one's mind the Paso Honroso written some forty years earlier. ${ }^{2}$ How great are the strides which Rivas' ever-youthful art has made in that interval ! No longer is there a catalogue of colours, affixed, as it were mechanically, to the robes and trappings of the combatants, but enhanced in brilliance by the sunlight which floods the canvas - a procession of knights and their retinues. The blue-liveried squires on their black horses, and the frequent blue and gold of the crests and shields give the sole touches of colour to what otherwise would have been a sombre scene. Then it is lit up by the scarlet uniform of a page, contrasting with the jet-black of his fellow, by the purple insignia and red plumes of a noble combatant, by the momentary gleaming of a golden lily : no more. ${ }^{3}$ There is more restraint here, where profusion is so easy, and there is infinitely more effect; but were it not for the Paso Honroso, Rivas' art might have been mistaken for artlessness.

The colourist of 1852 needs no occasions of

$$
\text { I. V, } 239 . \quad \text { 2. } V, 379 \text { ff. } 3 . \quad \text {, } 383-392 \text { passim. }
$$

special display for the exercise of his art as he did in 1812 . For he has learned to find colour everywhere, to bring it from its hiding-places where the untrained eye cannot reach it, and by a skilful stroke to weave it into the texture of his verse. And above all he has learned to portray the ever-present colouring of Nature, lovelier and more varied by far than the colouring of man. Thus it is that the tournament in "Maldonado" is by no means its most brilliant scene; that place of honour is reserved for a picture of sunset after storm which could hardly have been drawn but from the life :-

$$
\begin{aligned}
& \text { El negro manto de la noche horrible, } \\
& \text { Rasgado y roto por la mano excelsa } \\
& \text { Que de Aragón ampara los bajeles, } \\
& \text { Deja a trechos brillar vagas estrellas. } \\
& \text { Al fin marca en Oriente albor confuso } \\
& \text { Una línea ondulosa verdinegra, } \\
& \text { Tras la que empieza la anhelada aurora } \\
& \text { A dar de vida y paz al mundo señas. } \\
& \text { Los negros fugitivos nubarrones } \\
& \text { Que aún el espacio tormentoso llenan, } \\
& \text { A su pesar se ven engalanados } \\
& \text { De púrpura y de gualda con cenefas. } \\
& \text { Y aunque el sol no descubre su semblante, } \\
& \text { Su benéfica luz los aires llena, } \\
& \text { Y da al revuelto mar variados visos, } \\
& \text { Y las espumas férvidas blanquea. } \\
& \text { Rota la inmensa bóveda de plomo, } \\
& \text { Ver la del cielo azul a trechos deja, } \\
& \text { Y todo anuncia próxima bonanza, } \\
& \text { Y que la ira de Dios se calma y templa. }{ }^{1}
\end{aligned}
$$

So fine a piece of work in itself, and so exquisitely in harmony with its context, this marks perhaps as high a point as the Spanish colourist ever reached.

Standing beneath the relentless blue of an Andalucian mid-day, surrounded by luxuriant 


\section{RIVAS AND ROMANTICISM IN SPAIN}

foliage, snow-white blossom, and the brilliant hues which deck a Sevillan garden, one becomes convinced that colour is the dominant note of Spanish scenery. But the North restores one's sense of due proportion. From the Miradero at Toledo, for example, you may see clusters of whitewashed houses, buildings of golden-brown sandstone, fields of red loam, plantations of yellow mustard - a bright enough panorama, yet no more so than many a similar country scene in England which looks relatively drab and uninviting. A moment's reflection tells one why: the fact is that the genius of Nature in Spain is not colour but light.

Does Spain herself realise this? If not, perhaps that is the reason why a feature of Rivas' art so wonderful, so unique, so much rarer and finer even than his use of colour, has been entirely missed by those who have written about him. This feature is the constant use which he makes of images of light.

Scenes of light, indeed, appear to have haunted him like a passion, and from the beginning of his career onwards he reproduces them with all but unerring inspiration. $\mathrm{He}$ serves no long apprenticeship to this branch of his art, as he does to the mastery of colour. The most conventional of his early odes reveal flashes and glimpses of light. The poems of $18 \mathrm{I} 4$, many of which (sometimes with reason) have never since been reprinted, show a keen sensitiveness to the contrast of light and darkness, which after all, wonderful as it is, rarely finds worthy expression in poetry. Let the reader examine the spiritless eclogue $A$ delfa, ${ }^{1}$ a poem of some two hundred

I. I, $355 \mathrm{ff}$. The author styles this poem : "Imitación de Pedro de Espinosa," but the imitation seems to be only one of metre and general style, together with a few verbal reminiscences.
THE POET OF LIGHT AND COLOUR

71

lines, and he will find more than a score of phrases which may fairly be called images of light-most of them trite enough, it is true, but significant by their very number. A better example still from the early poems is a somewhat commonplace elegy written in $18 \mathrm{Ig}$, which tells of the poet's love for a certain statuesque "Olimpia." 1 In reality, that poem is less an outburst of passion than a study in darkness and light, crude enough, no doubt, in parts, but showing unmistakeable signs of power very shortly to be fulfilled. First the lover is straying, in a "dark and terrible night," seeking the clear, pure light which has vanished. His mind goes back to the day: it draws to a close, the sun's chariot descends, the pale stars appear, and again the reality of night is upon him. Follows the contrast of that "terrible night" and the burst of dawn. Day chases night, yet night once more succeeds day, and will ever succeed it : may the dawn break gently now, for the radiance of his lady's beauty has left him for ever, and he is " buried in eternal night."

Or there is a Nocturne, of the same year, in which young Saavedra gives full play to his love of light. ${ }^{2}$ In his two pictures, the first of a starlit sky, the second of a cold moon shining on the snow-capped peaks, the commonplace has all but disappeared, and the language is a scarcely clouded mirror of the poet's imaginings :-

Noche serena y pura,

$Y$ vosotras i oh estrellas!

Que brilláis en el cielo vagaroso,

Desde la inmensa altura

Al suelo dando, y plácido reposo . . .

$\begin{array}{ll}\text { I. I, 333-7. } & \text { 2. I, } 37 \text { I-4. }\end{array}$ 
$\mathrm{Y}$ tú, luna argentada,

Que blanca resplandeces,

Húmeda, y silenciosa, y sola, y fría

En tu rueda elevada,

Y la nieve esclareces

De las cercanas cumbres de Fonfría . . . 1

True, in the following lines, the clear-cut image gives place to the conventional lament, but these two pictures dominate the poem until they are dispersed by the gorgeous hues of sunrise:-

Mas i ah! que ya el Oriente

La soñolienta aurora

Esmalta con sus puros rayos de oro,

$Y$ de púrpura ardiente

Los celajes color

$\mathrm{Y}$ aun inunda mi faz amargo lloro. ${ }^{2}$

If such passages can be found in abundance before the Emigration, what shall be said of the Moro Expósito? For here, more truly perhaps than anywhere else in Rivas' works, it may be said that his whole canvas is flooded with light, whether it be that of the rich, brilliant Cordoban mid-day or the cold merciless dawn on the tableland of Castile. At the very outset of the poem-on its first page-the moon reigns serenely over the heavens in pearl-like splendour, and its tremulous light is reflected in the ocean sleeping silently on the shores beneath. ${ }^{3}$

Metaphors and similitudes of light abound. Zahira is "fair as the day-star, which ends the night and ushers in the dawn." She shines for

$$
\text { I. I, 371. 2. I, 374. }
$$

3. III, 3 , where

tranquila en el celeste espacio

Reina la luna, de luciente nácar

Entre celajes, y en el mar riela

Que duerme mudo en las vecinas playas.

The opening passage of which this is but a small part is admirable in conception and construction alike. a time upon the earth, and then "like some glorious exhalation departs." 1 Her last earthly moments are the "splendours of a dying fire," and as she speaks to her Foundling son upon her death-bed "her lovely eyes for the last time glow with heavenly flame." Kerima's love for Mudarra, too, is described in terms of light. It is no mere "flying spark," no flash or "flake of fire," no gleam of light which momentarily breaks a dark cloud. Nay,

It is the sun itself, the sun that fires her.

Love "shines in her eyes," and, when a disconcerting fear suddenly veils that light, Rivas sees his favourite image of a "fleeting cloud, driven by the wind, which dims the sun's radiant light, and darkens the smiling meadows beneath."

The supreme example, however, is to be found, curiously enough, in passages relating to, or incidents related by the blind old father, Lara. We may recall Lara's story of his visions in prison. The background is the darkness of night, to which succeeds "an atmosphere of fire" and the vision of a sea of blood, in which wade seven headless bodies. The scene is changed : lit only by a cold and misty light, the seven pale phantasms steal slowly across a sandy plain, crying for vengeance. Then all is dark.

Ah, what night! what night ! 3

Only after months of anguish and fever does there

I. III, 7

$$
\begin{aligned}
& \text { Bella como el lucero refulgente } \\
& \text { Fin de la noche y precursor del alba .. } \\
& \text {... . Pronto huyó, cual brilla y huye } \\
& \text { Luciente exhalación. }
\end{aligned}
$$

2. III, 66, 11. 5-8. 3. III, 252 . 
come the liberating vision of peace, which is a vision of radiant light :

$$
\begin{aligned}
& \text { Víme, pues, entre nubes y celajes, } \\
& \text { Que de oro el sol y de risueñas tintas } \\
& \text { Matizaba esplendente : en un abismo } \\
& \text { Bajo mis pies al mundo descubría } \\
& \text { Envuelto en sombras densas, y un torrente } \\
& \text { De purísimas luces difundian } \\
& \text { Sobre mí las estrellas. Luego escucho } \\
& \text { Són celestial de música divina, } \\
& \text { Y abriéndose los cielos, entre un coro } \\
& \text { De eternales espíritus, divisan } \\
& \text { Mis ojos siete jóvenes gallardos } \\
& \text { Que en esplendor al mismo sol vencian. } \\
& \text { Eran sus vestes como nieve puras; } \\
& \text { Azucenas que el tiempo no marchita } \\
& \text { Coronaban sus frentes; en sus manos } \\
& \text { Palmas eternas, venerable insignia } \\
& \text { De los mártires santos ostentaban ... . } \\
& \text { De gozo y desperté. La luz del dia } \\
& \text { Llenaba mi prisión. }{ }^{1}
\end{aligned}
$$

Thereafter, in speaking of the blind father, Rivas continually plays upon the themes of light and darkness. Lara enters his palace grounds, begs his faithful Nuño to place him " in the open air where he may enjoy the warm rays of the lifegiving sun in peace." It is a magnificent day, one of those that light up mid-winter in Spain; and Lara, at home after his long exile, bathes in the light and warmth of the sun he cannot see. He raises his head, "seeking perchance to feel the splendour of its rays," hoping against hope to "temper the long darkness" he has endured and to see at least some feeble brightness. $\mathrm{He}$ is doomed to disappointment : for " even had not one sun, but a thousand, poured upon him torrents

I. III, 253-4. (Italics ours.). The images of light continue beyond this passage, but space forbids further quotation. of light, his eyes had still been as senseless as brass or steel."

The reader who, with his imagination open now to impressions of light, will study the legitimation and bridal scenes anew cannot fail to realise the significance of the place taken by white in the poet's scheme of colours. It is but another aspect of Rivas' obsession with the theme of light, a desire to illumine to its utmost capacity every picture that he paints. Similarly, the tone of black which characterises the Romances Históricos is responsible for some of the dimness of these narratives, by comparison with the Moro Expósito or the Leyendas. Yet if Rivas cannot get light on his canvases by one means, he will procure it by another, and sometimes his devices are strange ones. In "Don Allvaro de Luna" the rays of the sun are reflected from the headsman's axe, ${ }^{2}$ and Don Enrique's naked dagger gleams like a ray of light from heaven. ${ }^{3}$ Another poem shows Doña Ana de Mendoza, her hair turned to purest gold and her jewels to stars by the shafts of light falling from the candelabra. ${ }^{4}$ And occasionally, when neither sun nor moon, nor candles nor lamps can be made to give their light, we are reminded that there is a glory which is of neither. Let this description from "El Conde de Villamediana" speak for itself :-

\section{En los soberbios jardines}

Brillan vasos de colores,

Que en el estanque reflejan

Un gran fuego de artificio

Las densas tinieblas rompe,

Y rastros de luz envía

I. III, 254-5.

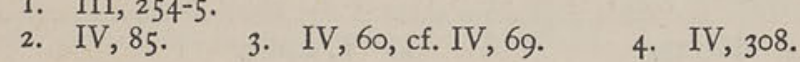

De los rayos que le lanzan Los nublados tronadores, Dijérase que la tierra

aba vengando entonces.

Varias encendidas ruedas, Girando luego veloces En atmósfera de chispas, Parecen mágicos soles ; 
76 RIVAS AND ROMANTICISM IN SPAIN

Mas pronto en huecos tronidos

De humo blanco alzando un monte, Se disipa, y desparece Aquel gigantón enorme

De luz, que ofuscó los astros,

Y que deslumbró a la corte Como trasunto o emblema Del orgullo de los hombres. ${ }^{1}$

So again to the Leyendas, where once more the art of this elderly but youthful poet is seen, not in its decline, but at its height. The passages which describe Sevilla, Naples and Granada are among the best known in the collection, and each of them will be found to depend very largely for its effect upon the vivid impressions of light which it conveys. It is moonlight, however (and the same is often true of the earlier collections) which strikes the poet's imagination most keenly of all No longer content with phrases and sketches, he gives us studies which are poems in themselves:-

¡ Cuán clara y refulgente, Y la pomposa encina, Espléndido topacio, $\quad \mathrm{Y}$ el contorno del monte En el vago horizonte,

Ostentaba la luna su esplendor, De nácar sobre nube, en dibujar.

\section{Con sonrisa inocente} Dormida entre celajes, Delicados encajes

Que nadie mirar osa ve niebla y cándido
vapor! descubrir ;

$\mathrm{Y}$ su luz argentina Por lomas y collados, $\mathrm{Y}$ silenciosos prados Se gozaba apacible en resbalar ;

Y sólo, allá en el fondo, Dejaba en la corriente Del rápido torrente Breve y fugaz destello relucir. 2

One other sustained light-image of a very different kind deserves to be known as an example of Rivas' maturer art. 'This is the description of the bonfire in the cathedral square of Badajoz,
I. IV, 335 .
2. $\mathrm{V}, 248-9$.

which, though purely an accessory to the story, plays an unusually prominent part in the first two cantos. ${ }^{1}$ The poem opens with a characteristic picture of the autumn sun sinking beneath crimson mists to its rest in the western sea and lighting up the towers and spires of the city with its dying rays. Once night has set in, the cathedral square becomes the centre of revels. A "flaring bonfire" has been lit, and the children, fascinated by its "facile flame," play around it, even as the poet's imagination, equally fascinated, plays. It lights up the square, and shines on the cathedral, the distant towers, the houses and the faces of the revellers - casting fantastic gleams upon all who venture within its sphere and no less fantastic shadows which shift uncertainly to and fro and take the strangest forms.

Even so far the poet has turned his bonfire to good account, but in the following canto he uses its reflection to illuminate his "sinister group" and in particular to draw lightning-flashes from the eyes of the Chief Conspirator! Finally, he even has the boldness to set the light of the bonfire in the radiance of the moon,-one may venture to think without ill success :-

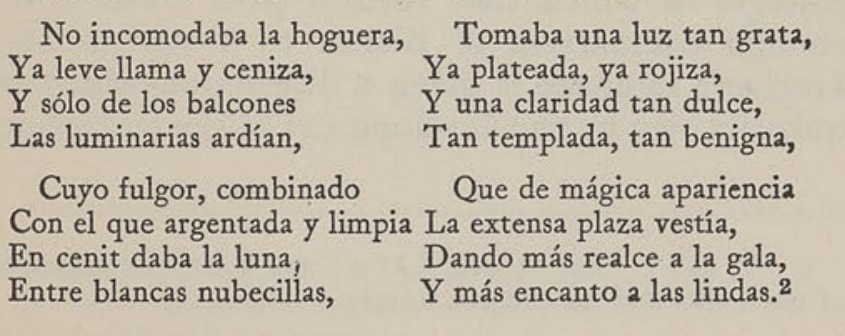

Entre blancas nubecillas, Y más encanto 2 las lindas.

I. V, 405-6. Cf. also pp. 410-II, where the poet plays

further upon his theme. endeavours, less happily, to sustain the effect. 


\section{RIVAS AND ROMANTICISM IN SPAIN}

In these lines we have indeed a daring imagination, combined with a highly-developed art.

The same is often true, in this collection, of images which in their intrinsic effect are less noticeable. There was a time in the history of Rivas' art when his references-for example,to the "light of the eyes" were frequent and meant little. It is no longer so now. When the false Rodrigo has told his deceitful tale to his master :-

$$
\begin{array}{cc}
\begin{array}{c}
\text { Los ojos de Nuño relum- } \\
\text { braban }
\end{array} & \begin{array}{c}
\text { Y lumbre azul, cual arde } \\
\text { sobre un muerto, }
\end{array} \\
\begin{array}{c}
\text { Cual brasas encendidas, } \\
\text { Y acaso espanto daban }
\end{array} & \begin{array}{l}
\text { Los ojos de Rodrigo } \\
\text { Daban en el desierto, }
\end{array} \\
\begin{array}{c}
\text { A las aves del todo aún no } \\
\text { dormidas. }
\end{array} & \begin{array}{c}
\text { Sin osar revolverlos a su } \\
\text { amigo.'. }
\end{array}
\end{array}
$$

Each of these stanzas conveys a definite imaginative picture, which may be exaggerated, in its conception or intensity, but is at least, to it author, real. The allusions, conventional in themselves, to the Catholic Monarchs ${ }^{2}$ and to Granada ${ }^{3}$, and the circumstantial description of the lists in "Maldonado" are lit up with the reflected glory and cumulative light effects of the passages of which they form a part. The trite enough comparison of Blanca to a star in her brother's serenade is given a distinction which is quite its own by the development of the metaphor

I. V, 246-7. But cf. $409,11.2 \mathrm{I}-2 ; 4 \mathrm{I} 4-5$ for reminiscences of the earlier and meaningless figures.

$$
\text { 2. V, } 230 \text { : }
$$

De alta prudencia y de

denuedo soles,

Que hoy en gloria sin fin están brillando.

3. $V, 230$ :

Magnífico diamante, Rico joyel de la diadema augusta

Tel imperio español.
THE POET OF LIGHT AND COLOUR

79

in the first stanza, ${ }^{1}$ and the interposition of the brilliant image which it evokes between the "noche tétrica" of the initial stanza and the "negro vértigo" of the second. And passages like these are the best justification of those wearisome commonplaces of light which every reader will remark, if he looks for them in the earliest lyrics. For it was by their means that the poet's best gifts achieved success in working out their own salvation, and winning their merited place in the annals of literary art.

\footnotetext{
I. i.e. Cuando la fúlgida Luz de una estrell Benigna y bella

Ví relucir :

Y eras tú, Blanca mía,

La estrella de consuelo y de alegría.
}

$(V, 253)$ 


\section{CHAPTER V}

THE POET OF THE SOUTH

"Andalucia, land loved of God!" So the Southerner salutes his native soil, and the stranger, as he echoes his words, believes that he can also share his feelings. In reality, those feelings can be shared by none; by few can they be truly understood.

We speak of the beauties of Italy-the majesty of Vesuvius, the glories of the Bay of Naples. But when Rivas, an Andalucian, went to Naples in 1844 , he declared roundly, in one of those interminable triplet-epistles, that the tales which he had heard of its wonders were "falsehoods and inventions," that the place was in short "abominable."1 They had told him how its January was like May in Sevilla, whereas here on the first of April the sea was at its stormiest and snow was lying on the mountains. The wind was bitter; every day it rained; not a tree was in leaf. Ah, how fragrant would be the jasmine and the tuberose at home!

Later, as a second epistle tells us, the poet was somewhat melted by the Neapolitan spring and the charm of the Italian people. But before long we find him again comparing the city of which it is said "See Naples and die !" and that other which, though it has earned a less audacious

I. Todas eran mentiras e invenciones,

Que es Nápoles país abominable, $\mathrm{Y}$ el peor que hay del Sur a los Triones. (II, 296, April 2, I844).

proverb, ${ }^{1}$ was nevertheless to him the sum of beauty. He writes more temperately now, though not less passionately, ${ }^{2}$ and always in the spirit of that earlier outburst which is typical of as sturdy a regionalist as ever won a place in Spanish literature.

One can hardly be surprised at his returning so often to the South in his work, when one thinks of the happiness of his childhood in Córdoba. ${ }^{3}$ In its gardens and woods he spent his happiest hours, learning to love the broad and placid Guadalquivir which from exile he invokes as it were his tutelary deity. As a child he had gathered flowers and played with pebbles and shells upon its banks; as a boy he rode or walked beside it; as a youth he sang to it of love and whispered to it his triumphs and his sorrows. ${ }^{4}$ All this and more he tells us in his verse. Within the city he could realise all that the Moorish dominion and the Spanish reconquest had brought of gain and of loss to Andalucia. There he read the story of the Abencerrajes and reenacted the siege and fall of Granada. ${ }^{5}$ And Córdoba itself appealed to him no less : memories of its greatness, and "shades of its generous heroes" were ever

. "Quien no ha visto Sevilla, no ha visto maravilla."

2. V, 257: Y en Nápoles, en fin, la que en el mundo Tanto renombre esclarecido goza;

A ti, y tan sólo a ti tengo delante, Y en ti i grata ilusión! mi mente mora.

3. ... Aquella insigne Córdoba, do el cielo Me dió el nacer, y que jamás olvido. . (Florinda, Canto III, 36).

4. See the lines in Canto VI of the Moro Expósito (III, 222), beginning :

¡Córdoba insigne !...; and cf. "El Desterrado" (II, 43). 5. Florinda, Canto III, passim. 
presenting themselves to his impressionable mind ; while the trophies of the conquest he could look upon, but "not without tears." Those tears often returned, in early manhood, for another cause, and from Malta he could cry to his birthplace :-

Jamás mi amor a ti, jamás se entibia,

$\mathrm{Ni}$ de mi pensamiento un punto sales,

Desde que arrastro en extranjeros climas

La vida, ha tantos años sustentada

Con el amargo pan de la desdicha,

$Y$ aun más con la esperanza de que al cabo

Logren en ti reposo mis cenizas. ${ }^{1}$

Not even in 1834 , when he returned to Spain, was Rivas able to enjoy to the full the companionship of Andalucia. But a few years later, when a political crisis sent him for a time into retirement and he went to live at Sevilla with his brother-inlaw Cueto (Marqués de Valmar) there began for him one of the happiest periods in his life. Some, no doubt, condoled with him on the "misfortune" which caused him to leave politics. "But where was the misfortune," asks the Marquis joyously, " in what our retirement from public affairs condemned us to ?" His answer has the ring of the Southerner's true home-joy:

"To live in the intimacy of our homes, untroubled by annoyances or anxieties, with leisure to enjoy and cultivate literature and art ! And this in a land where the country is full of flowers, the air full of fragrance, and the heavens full of light; where the people have nought but grace and charm, and memory can recall only glorious and romantic deeds! How often, in those enchanted nights of an Andalucian spring, by the side of some pool in a leafy garden, in an

I. Moro Expósito, Canto VI (III, 222). atmosphere fragrant with the scent of orange and jasmine, did we spend delicious hours in reading or in pleasant talk with our friends."1

These are but some of the recorded descriptions of Rivas' life in the South. Many more can be read, or inferred from his poems and plays: more still can be imagined. He seldom lost an opportunity of dwelling on Andalucian scenes and memories: even in the unpromising context of a Castilian narrative he could extol his native soil, and did. ${ }^{2}$ The story of Florinda, ${ }^{3}$ in accordance with fact, opens in the neighbourhood of Toledo, on the fertile shores of the Tagus. But we are not long in arriving at the "farthest confines of Spain," at the "coasts lashed by the angry sea." We are in the heart of the poet's own country, of its "lilies and jasmine," its "fruitful cornfields," its "scented meadows watered by fairest streams." 4 And there the poet stays, in the company of his sacred Guadalquivir, "el Betis olivoso"

$$
\text { . . risueño y caudaloso, }
$$$$
\text { Lo mejor de la España fecundando, } 5
$$

- that great river which we continually see in the early poems, and yet more clearly in the later Moro Expósito.

It is in this last-named work that the exiled poet found his best opportunity of extolling his native kingdom. For the plan of his poem allowed him to place in continual contrast, not only the scenery of the north and the south of Spain, but the splendours of the Moorish régime

I. Cueto: "Discurso Necrológico en elogio del Duque d Rivas," ed. cit., pp. 59I-2.

2. Paso Honroso, ii, $56 . \quad$ 3. Florinda, $\mathrm{i}, \mathrm{x}$

4. Florinda, iii, $60 ;$ iv, $8 . \quad$ 5. Ibid. iv, 37 . 
with the poverty of Castile. This may be thought a theme hardly worthy of a Christian poet, but one cannot remind oneself too often that Rivas wrote primarily for the imagination of his readers, and not for their spiritual edification. This same fact accounts for his comparative indifference to strict historical accuracy: while consulting such sources as were available in Malta, he constructs his pictures rather by imagination and memory than by processes of scientific research

Córdoba, Rivas' birthplace, becomes in a sense the heroine of the first part of the Moro Expósito. Even the reader who knows nothing of Andalucia quickly learns to visualise the scenes so frequently repeated : the " eternal palms," the Guadalquivir silently washing the shores of the great plain, the lofty towers and proud palaces of the majestic city standing out against the horizon. ${ }^{1}$ We may stand upon the heights with Mudarra (or with Rivas) looking down upon the city of his birth which he has left, knowing not if he is ever to return :-

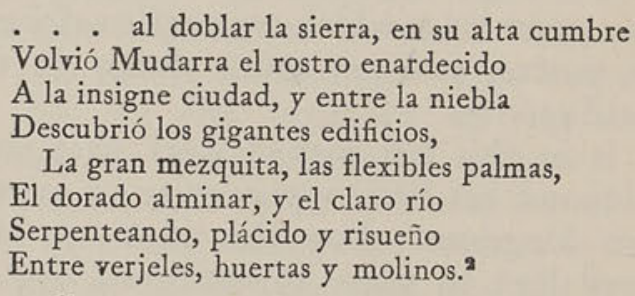

We have glimpses of the city, too, in greater detail: of its tranquil gardens, its majestic Alcázar, the grounds of that Zahara of which not a trace now remains, the Carrahola tower against which the fury of the storm avails nothing.
I. III, 4,85 .
2. III, $20 \mathrm{I}-2$

And we have the city (as Rivas reminds us) in the days of its greatness-days which can only be reconstructed now by those whose imagination can transcend bounds of time, who can erect and people buildings which have long since disappeared, bring colour, life and gaiety back to deserted ruins, and picture the brilliant Moorish civilization of centuries past and the worship in that mosque which, with its forest of columns and arches, is so strangely unlike a Christian cathedral still. These were days of continuous festival-banquets, jousts, dances, tourneys, and the peculiarly Moorish zambras reigned supreme.

Even when the poet leaves the city itself he loves to linger in its neighbourhood. No reader who has known that country of enchantment, walked in its blossom-laden gardens, and breathed its fragrant air, can fail to be thrilled by the pictures and apostrophes of the Moro Expósito. Those superb nights, when the sun goes down in his gorgeous robes, and the breeze sinks to rest among the flowers, are faithfully and tenderly described with all the emotion of one who had not seen them for many years :

$$
\begin{aligned}
& \text { Jazmin y azahares respiraba el aura, } \\
& \text { Y entre las flores reposaba el viento. } \\
& \text { Era una dulce y sosegada tarde } \\
& \text { De las que en aquel clima y grato suelo } \\
& \text { Naturaleza ostenta, y con que encanta } \\
& \text { Las tiernas almas, los sensibles pechos. }{ }^{1}
\end{aligned}
$$

Rivas was to write little more of Córdoba when once he had left it for Burgos in this exile-legend. ${ }^{2}$ Ere he turns from it, then, he paints one last fulllength picture of the country in which it is set, ${ }^{3}$ I. III, 63 .

2. A notable exception is to be found in the Romances Históricos (IV, II2).

3. III, $22 \mathrm{I}-2$. 
before breaking into that apostrophe of the city which is one of the passages best known to his many readers :-

¡Córdoba insigne ! ¡ Oh patria, dulce patria!

En cuyo seno de la luz del dí

Gocé la primer vez ....

Sevilla, where he later made his home, retiring to his house there as often as his duties allowed him, is as prominent as Córdoba in his thoughts. The bond between the two is the Guadalquivir, a river which has taken so firm a hold on the Andalucian mind, as symbolical both of the fertile soil which it waters and the light and colour of the sky and the landscape which are mirrored in its depths. It is never far from Rivas' mind. When only eighteen, he is singing naively to the Guadalquivir as it rolls down to the sea :-

$$
\begin{aligned}
& \text { Id, aguas puras, } \\
& \text { Id a Sevilla, } \\
& \text { Buscad en ella } \\
& \text { Mi amor y vida . }
\end{aligned}
$$

While in his greatest narrative poem he handles the majestic name with dignity, giving it a sonority justified by that bold line which recalls Gongora's famous sonnet :-

¡ Sevilla ! ’ Oh nombre mágico, que encanta

Con su apacible són mi mente toda

$$
\text { Guadalquivir, gran rey de Andalucía. }{ }^{3}
$$

When the use of an old story of his childhood as the basis of Don Alvaro, or some other motive unknown to us, led Rivas to place the scene of his play in Sevilla, he turns rather to the city itself than to the river and the surrounding country

I. III, 222 .

2. See, e.g., the apostrophe in the Leyendas $(\mathrm{V}, 256-7)$ :

3. III, 221. Cf. III, $20,63,78,33 \mathrm{I}, 5 \mathrm{I} 2$, etc. for his local colour. After ten years as an exile, he is still the poet of the South, and he paints familiar spots with an unsurpassable enthusiasm. The opening stage directions reveal that typical Andalucian scene already described - an aguaducho in the Triana suburb, picturesque enough setting for the rustic meeting which takes place there each night so soon as the summer sun has gone to rest. The Alameda in the background, the buerta set off by tall cypresses, the familiar national types, the regal yet homely river-no detail is lacking to give the Southern tone to the play from its beginning. ${ }^{1}$ Then there is Hornachuelos: even the Spaniard of another region will recognise his country in this picture. A romeria is on foot, and the village is all animation. Here we have the inn with its conglomeration of miscellaneous characters-natives and travellers, the muleteers, the innkeeper, the village gossip, the student and the alcalde. ${ }^{2}$ There we are on the bleak and precipitous hillside, the deep-cleft valley extending before us, with no other sign of habitation than the humble monastery on the one hand and the tiny hamlet in the distance. ${ }^{3}$ When we leave Spain for Italy, ${ }^{4}$ the "smiling countryside" resembles the buerta of Sevilla as surely as the "Siena" of Calderon's Devoción de la Cruz resembles the wilds of Castile. And finally we return to Hornachuelos, to a district famous for a peculiarly national religious legend ${ }^{5}$ : it is here that the drama ends. ${ }^{6}$ Nor is it without signi-

1. VI, 231.

2. VI, 265. 3. VI, 280 .

lvaro, Act III.

5. See Guichot y Sierra : La Montaña delos Ángeles. Sevilla, 1896.

6. Don Alvaro, Act V. 
ficance that Don Ålvaro and Doña Leonor first met in the "proud temple of Sevilla"1 and that he invokes Sevilla and the Guadalquivir in the most impassioned of the soliloquies of the play. $^{2}$

In later poems Rivas returns again and again to Sevilla, which, now that his family was settled there, was becoming dearer to him than Córdoba. We need not admire the workmanship of his lines to Sevilla Cathedral in order to applaud their sentiments. Far finer tributes to that great temple are to be found here and there in the Romances Históricos, which render to Sevilla the homage that the Moro Expósito gave to Córdoba. ${ }^{3}$ All the sights of the city receive their due : the lofty tower with its graceful Giraldillo to point to the changeful wind, the Torre del Oro and the church of Santa Ana, on the banks of the Guadalquivir ; the magnificent Alcázar with its charming gardens; the suburb of Triana and its bridge; the brazen-tongued Giralda bells which continually call the city to prayer and go out to all the world declaring Sevilla's praise 4 . No less elaborate are the general impressions : the wealth of orange and jasmine which enchants the eyes and gives its fragrance to everything around, the murmur of springs and streams, the far-off sound of bells, as we linger in Sevilla's surrounding

$$
\begin{aligned}
& \text { I. VI, } 360 \text { : ¡ Hora de maldición, aciaga hora } \\
& \text { Fué aquella en que te ví la vez primera } \\
& \text { n el soberbio templo de Sevilla .... } \\
& \text { 2. VI, 3Ir. i Sevilla!!! ; Guadalquivir !!! } \\
& \text { ¡Cuál atormentáis mi mente! } \\
& \text { i Noche en que ví de repente } \\
& \text { 3. E.g., IV, 395-6, 398-9. } \\
& \text { 4. IV, } 7,11,21-2,23,165,395
\end{aligned}
$$

" garden," the narrow and winding streets through which we must thread our way when we return. ${ }^{3}$ All this is repeated in the Leyendas, though with variations of which the author could be prodigal at will. So while we still see the majestic Gel Oro, the Alcázar and Cathedral, ${ }^{2}$ we have glimpses also of the swarms of boats upon the broad bosom of the river, ${ }^{3}$ the treasures of Murillo and Zurbarán ${ }^{4}$, the Giralda amid rosy mists and the echoes of its sonorous voice among the hills. ${ }^{5}$ While nothing that Rivas ever wrote has more of the eloquence of sincerity than his digression upon Sevilla in the narrative of the Miraculous Lily. ${ }^{6}$

Next to Córdoba and Sevilla in importance, but far below them, comes Granada, the city of the Alhambra, scene of the Moors' last long stand ere the Christians encamped at Santa Fe and their faith was crowned with victory. In the Romances Históricos is described the somewhat unpleasing cathedral erected to commemorate that victory, but it is the first of the Leyendas which makes Granada notable in Rivas' work. What a wealth of detail goes into the fashioning of that picture,its lofty towers and magic palaces, its twin streams, the Genil and the Darro, the gorgeous Alhambra and the uncouth Albaicin, the snowy Sierra above and beyond, and the broad Vega around. But principally and always the poet's around. But principally and always the poet's would expect) is with the floods of light which the

I. IV, 23-4.

2. V, $256,257,262,270$.

3. $\mathrm{V}, 263$.

4. $\mathrm{V}, 257-8$.

5. Ibid.

6. $\mathrm{V}, 256-8$. 
90 RIVAS AND ROMANTICISM IN SPAIN

regal Andalucian sun pours over the city, mountains and plain, and gives Granada its supreme claim to the proud title of

Magnífico diamante,

Rico joyel de la diadema augusta

Del imperio español. ${ }^{1}$

It must not be supposed, of course, that Rivas drew no other parts of Spain than Andalucia. Several of his longer poems take the reader into the North. In the Moro Expósito he dealt faithfully, if a little cruelly, with Burgos: its stern unyielding walls, its strangeness to the sun, its cheerless environs - a country in which the peasants strive against a sullen climate and an ungrateful soil. Elsewhere are glimpses of the Guadarrama, Toledo's "gigantic towers," Zaragoza, Santiago, Montserrat-the list might be made a long one. But only of one region outside his own "country" does he seem to write with any real enthusiasm. This is the land of the Tagus, a river for which he shares the pride of some of his great predecessors. Both in early lyrics and late romances he applies to it all the caressing epithets of others, and some of his own. "Fruitful" Tagus it is, and "crystalline," "gold-bearing," and " rich" and " happy.", While yet he was in the bonds of pseudoclassicism, indeed, he addressed to that stately river one of the most melodious of his early lyrics, written in comparatively simple language and an inspired rhythm. ${ }^{3}$ But it must be remembered that this early affection for the Tagus is bound up with the military adventures

I. $\mathrm{V}, 230$

2. E.g., I, 224, 336, 345, 368, 375, 383; IV, 26I, 265.

3. I, 375-7.
THE POET OF THE SOUTH

to which he loved to return, and, if he once called Toledo the "diadem of Spain,"1 that country has many jewels, one of which may differ'from another in its glory.

IV 265 , cf. 25 I

De España Corte y diadema. 


\section{CHAPTER VI}

THE INFLUENCE OF ENGLAND

At one time and another in his career, Rivas felt very strongly the influence of English life and letters. He spent, it is true, but a few months in our country, yet again and again in later years he came into contact with Englishmen abroad; in the most troubled periods of his life, one is glad to reflect, many of them were able to be of use to him. For these, or for other reasons, the poet who was so pre-eminently of Spain and the South was also extremely sensitive to the influence of England.

During the Peninsular Campaign, and particularly in Cádiz, he had numerous objectives for his hero-worship, in notable Englishmen perhaps also opportunities of mixing with them, the more so on account of his literary activities, which could not but have enlarged his circle of acquaintances and made him better known. Some ten years later, a proscript, his thoughts at once turned to England. During his stay in Gibraltar, he no doubt extended his knowledge of English, as he was hoping to settle in London. Of his actual six month' stay there very little is known. He can hardly have been well off, since his intimate friend, Alcalá Galiano, was in straits, and the probability is that he earned money by writing for the Spanish periodicals which were published at that time in some number in London. Apart from possible prose, he certainly wrote there two cantos of Florinda, besides Cristóbal Colón and the Sueño del Proscripto. The

Desterrado, written in 1824 , was published in London over his initials in a journal called Ocios de Españoles Emigrados. Prose contributions to the Spanish periodicals of the Emigration, being mainly political, were for obvious reasons signed by initials which told no tales, such as W.Z.X., X.R.W., Y.Z., X.M. ${ }^{1}$ and others about as illuminating, with the result that one cannot tell if the future Duke was among the number or no.

Of Rivas' life in Malta little more is known than of his short stay in London. He was evidently a familiar, even a popular figure in English circles there, for in the Moro Expósito he goes out of his way to apostrophise, not merely his chief benefactor, Frere, but also a number of others. Notably he mentions the Marquis of Hastings, who was Governor of the island when he arrived and died during his residence there, General Sir Frederick Ponsonby, the next Governor, who had fought in the Spanish wars, and General Sir Alexander Woodford, whom he may well have known at Cádiz during the Siege, or after. ${ }^{2}$ The last-named soldier afterwards became Governor of Gibraltar, and befriended the Duke once more in 1836 when the political crisis of that year drove him there from Spain.

It is natural to assume that a man of letters in an age unusually susceptible to foreign influence should show in his work at least some traces of the effect of continually recurring intercourse with England and Englishmen for a period of nearly forty years. But apart from a few scant allusions,

I. These particular examples are from the Emigrado Observador.

2. III, 265-6. 
such traces do not appear on the surface; and previous studies of Rivas have not gone farther than to suggest that his experiences may conceivably have had some effect on his writings. They have seen the possible influence of Scott in Rivas' treatment of the verse romance, or conjectured that in writing Don Alvaro he may not improbably have taken some points of technique from Shakespeare. In point of fact, he did a great deal more. In three of his principal works there can hardly be a doubt that he drew freely from Shakespeare, Scott and Byron : in two of these the resemblances are so close that one would suppose he had the English author at his elbow.

The principal sources of the Moro Expósito, as has already been explained, are certain versions of the legend of the Seven Sons of Lara. In its leading features the poem follows closely the traditional story, and it is fairly easy, with the evidence-internal and external - at our disposal, to say which were the versions that Rivas used. Large portions, however, of the plot of the Moro Expósito, and most of the descriptive passages, have never yet been traced to any original. Some of them no doubt are Rivas' own, but for others he was undoubtedly and startlingly indebted to Sir Walter Scott's Ivanboe.

Once the two works have been read side by side, it is impossible to question Rivas' indebtedness. It might even be supposed that he had been reading Ivanboe at the very time when he was beginning his romance, and that he appropriated its detail in places where, by pure chance, his plot resembled that of the novel. True, the verbal resemblances are few, and the conventions of historical romance may explain some proportion of the similarities. But when every possible allowance has been made, the residuum of evidence for direct influence is overwhelming. Let the unprejudiced reader judge.

In any two accounts of a mediaeval tournament or duel, there would of necessity be certain resemblances. A comparison, however, of the wedding jousts in the Moro Expósito and the tournament in Ivanboe 1 shows two accounts constructed on practically identical lines. In each narrative the contest is held in a large open space, crowded with spectators, of whom the gently born sit in temporary galleries, the remainder being accommodated below. In the highest seats of one balcony is Rivas' Count Sancho-corresponding to Scott's Prince John-who is attended by an archbishop, as John is accompanied by the wealthy Prior of Jorvaulx. In the midst of the clamour before Rivas' jousts begin, the seven Infantes ride up and down in the lists; just so do John and his numerous train upon their entry. After the "clangour of trumpets," the lists are entered by five challengers bearing lances (in each narrative), one of whom is recognised as leader.

Alvar Sánchez overthrows twelve of his opponents; in Ivanboe also the challengers are victorious. Then comes a pause, for it did not seem " that anyone was very desirous of renewing

I. M.Ex. II $4 \mathrm{ff} . \quad I v .88 \mathrm{ff}, \mathrm{I}_{62} \mathrm{ff}$. References relating to Ivanhoe are given to the Large Type Border Edition of the Waverley Novels throughout (ed. Lang, Nimmo, 1898). As I hope at a later date to work out the whole matter of Scott's influence on Spanish literature more fully, I have not given exhaustive references here.

2. Rivas has "Los recios sones De timbales y trompas."; 
the contest." In Scott's narrative, the challengers' music and the heralds' proclamations fill up the interval, while the refusal of Athelstane to "take the lance" gives the fool Wamba an opportunity for sarcasm. ${ }^{1}$ This perhaps suggested to Rivas that Doña Lambra's jester might occupy the time, and divert the vulgar, with his merry antics.

Presently, however, in each narrative, there enters a single champion. $\mathrm{He}$ is announced by trumpets, silence and expectation greet his arrival, and he is found to be an unknown knight who seeks to challenge the leader of the victorious party. A commanding and graceful figure, he at once wins the favour of all. ${ }^{2}$ Says Scott :-

The dexterity with which he managed his steed, and something of youthful grace which he displayed in his manner won him the favour of the multitude. 3

And Rivas echoes:-

Such were his grace and courtesy, so great were the dexterity, elegance and ease with which he managed his steed, and such were his nobility of form and the gallantry of his bearing . .

The feats of horsemanship displayed by both Ivanhoe and Gonzalo continue to attract the multitude. 5 Gonzalo's identity is, from his very prowess, guessed by many, though none will declare it ; Ivanhoe's, on the other hand, remains a secret. In both novel and poem the mob shouts advice and encouragement to the unknown knight; then, as the contest proceeds, "the clamour of applause (is) hushed into a silence so

I. Iv. $\mathrm{II}_{3}$

2. Iv. II $5 ; M$. Ex. II9.

3. IV. II

3. M.Ex.

5. Iv. II $5 ; M . E x .12 n$, deep and so dead that it seemed the multitude were afraid even to breathe."1

And now, as the encounter begins, Rivas uses Scott once more. "The trumpets had no sooner given the signal," wrote Scott, "than the champions vanished from their posts with the speed of lightning, and closed in the centre of ths lists with the shock of a thunder-bolt. The lances burst into shivers up to the very grasp, and it seemed at the moment that both knights had fallen, for the shock had made each horse recoil backwards upon its haunches. ${ }^{2 "}$ Rivas phrases it thus: "The trumpet sounded; Sánchez and the knight were off as swiftly as arrows; they closed, and each lance met the opposing shield, flashed fire and glanced off again, leaving a deep mark. The horses wheeled, both lances broke into shivers; but the knights continued the fight with others, and at last came to grips." 3

The second encounter sees the opponent of each unknown knight unhorsed, and each of the vanquished knights unsheathing his sword to continue the fight. ${ }^{4}$ The other, however, in each story, is declared victorious, and prepares to encounter the challengers who are left. It is at this point only that the path followed by Rivas diverges from Scott's.

I. Iv. II $7 ; M$. Ex. I2I.

Mientras la muchedumbre en gran silencio,

$\mathrm{Ni}$ aun osa respirar de miedo y pasmo.

Bois-Guilbert boasts to him as Alvar Sánchez had boasted at an earlier stage in the tournament.

2. Iv. 116.

3. $M . E x . \mathrm{I2I}$

4. Iv. II7-8; M. Ex. I22-3. 


\section{RIVAS AND ROMANTICISM IN SPAIN}

Near the end of each romance occurs a trial by combat, and here also Rivas seems to have followed Scott somewhat closely. Bois-Guilbert in Ivanboe is made to play the part of villain and vanquished, and, like Rui-Velázquez, he will only fight because reputation and honour are involved. In each narrative there is a vast concourse of spectators; the enclosure is again in the open air, " amply supplied with galleries and benches"; the president's throne is "surrounded with seats of distinction." Each narrative describes a procession in double file, in which one of the champions figures. The heralds, after examining the ground, warn non-combatants in almost identical terms. The second warrior delays so long before appearing that his coming is all but despaired of. At last voices announce his arrival ; he rides into the lists, and the duel begins. ${ }^{1}$

That much of all this is conventional may be pleaded here, but as we pass from action to character such a plea is no longer valid. Suggestions for Kerima-though slight onesoccur in some of Rivas' possible sources, but by far the nearest resemblance to her is to be found in Scott's Rebecca. The two girls are nonChristians in a Christian environment; both are supposed to possess supernatural healing powers, which both use in succouring the hero. Both are highly revered by all; and both would extend to all their gifts and sympathies. To each comes love, but bringing with it only sorrow, for each is compelled to renounce the man she loves and retires from active life with life's longing unsatisfied, yet dedicating herself to God. ${ }^{2}$

I. Iv. $6 \mathrm{Ig}$ ff.; $M . E x .48 \mathrm{I} \mathrm{ff}$.

2. Iv. $650 ; M . E x .586$.
THE INFLUENCE OF ENGLAND

The pompous abbot in Canto $\mathrm{X}$ of the Moro Expósito, to whom Rui-Velázquez repairs before the final combat, is a familiar figure to all readers of the poem. The description of him corresponds very closely with that of the Prior of Jorvaulx with his "well-fed, ambling mule," his mantle and hood " of the best Flanders cloth," and his sleeves "lined and turned up with rich furs." Like Prior Aymer, Rivas' abbot rules over a community enriched by the gifts of wealthy penitents; like him, he is timid in danger, but quickly becomes serene and dignified again when all is calm. ${ }^{1}$

For Álvar Sánchez, Gonzalo's gigantic opponent in the jousts, there was authority in Rivas' sources, but none for making him a giant ; this trait may well be an inspiration from the "gigantic Front-de-Boeuf," whose stature Scott emphasises with effect. ${ }^{2}$ The swineherd who becomes Ivanhoe's faithful follower may have suggested the introduction of Mudarra's devoted attendant, Vasco Pérez the podenquero-the more so as the attachment to both Ivanhoe and Mudarra of these humble friends follows on their home coming. ${ }^{3}$ A more striking similarity occurs with Rivas' entirely gratuitous introduction of a pilgrim, who gives Lara a reliquary containing a sacred piece of wood, presumably a relic of the True Cross. Just so, in Ivanboe, the assumed palmer had presented such a relic as security for the hero:-

"If Ivanhoe ever returns from Palestine, I will be his surety that he meets you."

"A goodly security!" said the Knight Templar, " and what do you proffer as a pledge?"

I. Iv. I4-15;M. Ex. 458 .

2. Iv. II 8-9, 280-I, M. Ex. II6.

3. Iv. Chap. VI, passim; $M$. Ex. Canto VIII. 


\section{IOo RIVAS AND ROMANTICISM IN SPAIN}

"This reliquary," said the Palmer, taking a small ivory box from his bosom, and crossing himself, "containing a portion of the true cross, brought from the Monastery of Mount Carmel."1

The burning of Rui-Velázquez' castle in Canto IX of the Moro Expósito was inserted no doubt as a pleasing digression, conflagrations of the kind being (especially to a painter) as attractive in fiction as in life. Scott's well-known conflagration scene would once more have been helpful and suggestive; the vision of Ulrica on a turret, too, may have given Rivas the idea for Elvida, who makes a similarly startling appearance at the duel. ${ }^{2}$

Of the numerous resemblances in minor details which can be added to these one only shall be cited. At the beginning of Ivanboe the homely Wamba sets an alternative before the travellers whom he meets on the road :-

"If the reverend fathers," he said, "loved good cheer and soft lodging, few miles of riding would carry them to the Priory of Brinxworth, where their quality could not but secure them the most honourable reception; or if they preferred spending a penitential evening, they might turn down yonder wild glade, which would bring them to the hermitage of Copmanhurst, where a pious anchoret would make them sharers for the night of the shelter of his roof and the benefit of his prayers."

These lines, it would seem, remained in Rivas' mind as he read them, took root and sprang up in his fertile imagination, and eventually were transformed into a powerful scene which has neither counterpart nor suggestion in the Spanish sources. On the eve of his fight with Mudarra Rui-Velázquez is wandering on the moors, casting about as to how from some holy man he may gain assurance of success. He bethinks him first of a lonely hermitage, where

I. Iv. p. $62 ; M$. Ex. pp. IIo-I.

2. Iv. 430,$432 ; M . E x .000$

3. $I v .22$
THE INFLUENCE OF ENGLAND IOI

a penitent dwells alone; then, after he has tried this and failed there, of a wealthy abbey where indeed he finds "good cheer and soft lodging" and gains (at suitable remuneration) false hope of success. ${ }^{1}$

We have travelled by this time some distance into the realm of conjecture, but the journey may perhaps be condoned by the relative certainty that the debts cited earlier are real ones. It is strange that those of Rivas' numerous critics who by a common literary device have eulogised him as the "Scott of Spain" should never have examined Scott's Ivanboe and discovered how much Rivas owed to this predecessor.

Equally unfortunate is it that all who have called Don Alvaro "Byronic" have not had sufficient self-confidence to study their Byrons. That well-worn adjective has been applied not only to Rivas but to most prominent writers of the early nineteenth century, and there is no sign that, as applied to the author of Don Alvaro, it denotes anything but the vaguest of resemblances, a mere similarity of conception, an attitude of mind. Pedigree-hunters have found two French sources for the play: Prosper Mérimée's tale Les Âmes du Purgatoire and the Antony of Dumas perre. Yet sources not less important than these, since they involve the character of the protagonist himself, are Byron's two poems Manfred and Lara.

Once we have read those poems we ask in amazement how the indebtedness of Rivas could never have been perceived. In conception Don Álvaro is almost one with Lara. Each is of "foreign aspect" and " high demeanour," com-

I. $M . E x \cdot 535$ 


\section{RIVAS AND ROMANTICISM IN SPAIN}

pletely "lord of himself," possessed of striking personal charm, and newly arrived in his native land after long years spent in a country of magic name ${ }^{1}$. Each has a "chilling mystery of mien" which leads speculation upon his origin and past life to do its worst. ${ }^{2}$ Of Don Álvaro, in short, in the opening act of the play, these lines might well have been written :

In him inexplicably mix'd appear'

Much to be loved and hated, sought and fear'd

Opinion varying o'er his hidden lot,

In praise or railing ne'er his name forgot :

In praise or railing ne'er his name forgot :
His silence form'd a theme for others' prate-

They guess'd, they gazed, they fain would know his fate.

They guess'd, they gazed, they fain would know

Who walked their world, his lineage only known ?

So soon as we come upon Don Álvaro seeking for death, we are no longer in Lara, but in Manfred. As he roams " with the fierce thirst of death—and still unslaked " he laments that death will not come to him :-

Yo que buscándola voy,

No puedo encontrar con ella . . .

Sólo $\ldots$ Mi ardor

Sólo es falta de valor,

Pues busco ansioso el morir

Por no osar el resisti

De los astros el furor. ${ }^{4}$

And this is surely suggested by the fate of Manfred, the more noticeably so because in Don Alvaro it is by no means entirely in harmony with the leading idea. Says Byron's hero :-

All hateful things conspire

To bind me in existence.

I. Lara, I, iv, v.

2. Lara, I, xix.

3. Lara, I, xvii.

4. Don Alvaro, III, iii (VI, 3 Io)
THE INFLUENCE OF ENGLAND 103

I feel the impulse-yet I do not plunge

I see the peril-yet do not recede;

And my brain reels-and yet my foot is firm :

There is a power upon me which withholds,

And makes it my fatality to live.

Manfred stands at daybreak on the cliff watching the pines "on the torrent's brink beneath"; Álvaro at sunset on a "scarcely accessible cliff, with a valley below him " intersected by a stream and "surrounded by briars and crags impossible to scale." The one throws himself down; the other is arrested in act to spring :Manfred :

\section{Clouds}

Rise curling fast beneath me, white and sulphury,

Like foam from the roused ocean of deep Hell ... Farewell, ye opening heavens!

Look not upon me thus reproachfully-

You were not meant for me-Earth! take these atoms !

$$
\text { Don Alvaro: }
$$

Infierno, abre tu boca y trágame. Húndase el cielo, perezca la raza humana ; exterminio, destrucción ... .

In the soliloquies of Manfred and Âlvaro on their past lives, in many a chance turn of phrase, and particularly in references to Destiny and Fate, further parallelisms occur, and many passages in both Lara and Manfred, though not reproduced in Don Alvaro, suggest that Rivas had read and absorbed them thoroughly. One line from Lara :

The hand that kindles cannot quench the flame. 4

might serve as an epigraph to the whole drama. Or, on another interpretation, we might write of Don Álvaro or even of his creator :$\mathrm{He}$ at last confounded good and ill, And half mistook for fate the acts of will.

I. Manfred II, iv.

I. Manfred I, ii.
2. Mara, I, xviii. 
Had Don Alvaro spoken to Doña Leonor at her last appearance, he might have addressed to her the words with which Manfred speaks to the phantom of Astarte :-

Thou lovedst me
Too much, as I loved thee : we were not made here nache The deadliest sin to love as we have loved.

Say that thou loath'st me not-that I do bear

This punishment for both-that thou wilt be

One of the blessed-and that I shall die.

This combination of definite parallels with more general resemblances leaves one no choice but to think that the influence of Manfred (perhaps also of Lara) was consciously strong upon Rivas as he wrote Don Alvaro.

Once more in his life the Spanish poet was to ransack the treasures of English literature and carry away proud booty ; this time he visited our greatest treasure-house, the drama of Shakespeare. The parallelisms which go to prove this last case of indebtedness are the most curious and interesting of all.

The work in which Rivas enshrined his trophies is one of his later dramas, El Desengaño en un Sueño. The title of this play recalls Calderon' La Vida es Sueño; but is is very little known, partly because it was excluded from the latest edition of Rivas' works, and partly because of its unsuitability for acting. Yet it has been called " the greatest fantastic drama in modern Spanish literature, comparable in profundity with the profoundest German plays, and at the same time decked out with all Calderon's poetic fancy."2

I. Manfred, II, iv.

2. Pacheco, in preface to Vol. IV of the 1854 edition of Rivas' works.
In it stage requirements are thrown to the winds, and instead of a conventional drama we have a succession of scenes,-or, as some, knowing Rivas' weakness, might prefer to say, a series of tableaux.

The scene is a " desert island in the Mediterranean," and the hero, Lisardo, is a youth who has been kept in captivity by his father Marcolán, an aged magician anxious to shield his only son from the dangers into which unrestricted commerce with the world might lead him. At the outset of the action, Lisardo is discovered bewailing his lot, and Marcolán resolves that his son shall taste reality in a dream without suffering any of the troubles which contact with reality itself may bring. He therefore puts him to sleep by supernatural means; the boy is visited by the Genii of Love, Wealth, Power and Evil; and a series of dream-scenes is enacted, directed by these Genii in turn.

The first of these consists in the wooing and winning by Lisardo of a beautiful girl named Zora, and the consent of her father being asked and given to their marriage. But the Genius of Evil appears, and asks: "What is beauty without wealth ?" Lisardo at once loses his newly-gained happiness, until wealth is granted him, upon which the Evil Spirit once more appears suggesting that power alone can make man truly blest. Thereupon Lisardo becomes a successful general. He rides in triumph into a "magnificent Oriental city" to all the accompaniments of Oriental splendour. $\mathrm{He}$ is graciously welcomed by the King and Queen whose dominions he has defended, but the lust for further conquests is upon him, and (his evil genius still whispering in his ear) he wins the Queen's love and compasses the murder of her 


\section{I06 RIVAS AND ROMANTICISM IN SPAIN}

lord to reign in his place. From this point his apparent happiness, which has reached its utmost limits, ceases. The blood on his hand terrifies him, and with it the fear that he, too, may be betrayed in his turn. By means of a ring which makes him invisible he learns that he has indeed enemies, who are likely to destroy him : his very queen is unfaithful. Only by means of the ring is he able to escape from certain death, to learn that Zora, whom he has cruelly abandoned, has died of a broken heart. In his bitter remorse he cries to the powers of Hell, and the devil, appearing, inspires him with new hope which is crushed by the prediction of an angel of light, against whom the devil is powerless, that his end is at hand. Surely enough the next moment sees him taken prisoner, and he is in prison, awaiting death for his crimes, when the dream ends, and Marcolán reappears to ask his son if he is still anxious to taste the world's experiences. The answer of the youth is not doubtful.

Even so brief an analysis as this will recall to the reader more than one Shakespearean scene, and further examination will show the influence of three-at the lowest estimate- of Shakespeare's plays: The Tempest, Macbeth and Hamlet. The most obvious source is the first. Rivas re-creates Prospero's lonely island; the Prospero-like Marcolán is a magician; his son, like Prospero's daughter, has spent all his life with him on the island. It is the magical powers of each father which cause and control the entire action of the play: Marcolán rules from his gruta as Prospero does from his "cell."1

I. Tempest, I, ii.
THE INFLUENCE OF ENGLAND IO7

Each play opens in a storm and in each is heard "a tempestuous noise of thunder and lightning."1 Lisardo, like Miranda, is put to sleep by the father's magic in a strikingly similar scene :- 2

Prosp.: Thou art inclined thespareAnd git inclined to sleep ; 'tis a good dulness, And give it way : I know thou canst not choose. Rivas(Miranda sleeps.)

\section{Lisard: I fain would rest.}

Marc.: Be't so, my son. (Apart) The charm begins to work ; I touch him with my wand : he sinks to sleep.

$$
\text { (He sleeps profoundly.) }
$$

Zora, again, is the first woman whom Lisardo has seen, as Ferdinand gives Miranda her first sight of a strange man. Each exclaims at the vision, using similar language :- ${ }^{3}$

$$
\text { Mir.: What is't ? A spirit ? }
$$

Lord, how it looks about! Believe me, sir,

It carries a brave form.

Lisard: What is't ?... RIVAsA woman! ... brave and fair ..

The two at once fall in love, and at the end of the love-scene Zora's father blesses the impending union, as Miranda's father does at a later stage of the Tempest. The blessing in each play, however, is conditional. 4 At the conclusion of Rivas' scene is something resembling the rustic masque which in the Tempest follows the betrothal ${ }^{5}$; it is probably inspired by it. Shakespeare's directions are: "Enter certain

I. Stage directions to $\mathrm{I}, \mathrm{i}$ of each play.

2. Tempest, I, ii; Desengaño, I, i.

3. Tempest and Desengaño, I, ii.

3. Tempest and Desengano, 1 , il.

4. Tempest, IV, I; Desengaño, I, 
I08 RIVAS AND ROMANTICISM IN SPAIN

Reapers, properly habited: they join with the Nymphs in a graceful dance." Rivas has "Enter from both sides a company of savages and sylphs who dance around the pair."

Lisardo's discovery that Zora has died of her love for him takes us to the best-known parts of Hamlet. The scene where Lisardo meets the funeral procession ${ }^{1}$ is a reminiscence of Shakespeare's "Gravedigger Scene"; for Lisardo, like Hamlet, talks with a gravedigger and endeavours to enter the grave of his loved one, for whom he declares his undying affection. Even before this point Lisardo's rejection of Zora is almost as mercilessly deliberate as the bolder and finer scene in which Hamlet mocks Ophelia ${ }^{2}$, while the celebrated "Play Scene "3 is surely mirrored in the crime $e^{4}$ which Rivas describes in an all but wordless scene as follows:LisARD : Enough, let us fly!

The tbrone disappears by means of the trap-door by wbicb it came, and in the space wbich it filled is discovered a massive door, and within, the King, sleeping on a magniticent purple couch, by the ligbt of a lamp. The wbole stage is in darkness but for this chamber Quren (giving bim a dagger, and sbowing the King):

$$
\text { All, all is there, Lisardo ! }
$$

(Lisardo recoils in horror. The Queen urges bim on, and suddenly be springs forward, raising the dagger as be does so. The curtain falls.)

The Queen's incitements to Lisardo, and her giving him the dagger, are suggestive rather of Macbeth than of Hamlet. She chastises him with the valour of her tongue, not indeed in identical, but at least in similar words :-

I. Desengaño, IV i.

2. Desengaño, II, ii; Hamlet, III, i.

3. Hamlet, III, ii.

4. Desengaño, II, ii.

\section{SHAKESPEARE-}

What, quite unmann'd in folly ? $^{1}$

Rivas-

What foolish fear dismays thee ?

SHAKespeare-

You mar all with this starting !

$$
\text { Art thou afeard }
$$

To be the same in thine own act and valour

As thou art in desire ?4

$$
\text { Rivas- }
$$

But dost thou tremble ?

Yea thou dost tremble! Can it be perchance

That thou dost lack the valour for this deed $?^{5}$

Her reply to Lisardo's timorous : "Asleep ?"

Asleep. And it is needful for our purpose

That he wake only in eternity. ${ }^{\circ}$

recalls the famous "If we should fail ? . . . We fail " 7 in the calmness of its confidence, and in its verbal expression the equally well-known dialogue

$$
\begin{aligned}
& \text { Lady: And when goes hence } \\
& \text { Macbeth: To-morrow, as he purposes. } \\
& \text { Lady: } \quad \mathrm{O} \text { never }
\end{aligned}
$$

The drugging of the grooms is in each play a preparatory precaution, for each king is murdered in his sleep. ${ }^{9}$ But much more noteworthy is the dialogue between Lisardo and the Queen when the deed is done. The latter part of it is almost a repetition of phrases from the Sleep-walking
I. Macbeth, III, iii.
2. Desengaño, II, ii
3. Macbeth, $\mathrm{V}, \mathrm{i}$.
4. Macbeth, I, vii.
7. Macbeth, I, vii.
1 , vii.
9. Macbeth, I, vii ; Desengaño,
Desengario, II, ii.

$$
\text { II, ii. }
$$


Scene in Macbeth. How strange it sounds-alike, yet somehow different!

\section{Queen: None, none suspects}

That that swift blow which on the throne has set the

Was from thy hand, or if there were suspicion,

'Tis quickly pass'd.

Lisardo (in confusion): From my hand ?, . Even so . .

$$
\text { To kiss it. }
$$

Lisardo (borror-struck) : How, my hand ?
Thy hand, indeed.$$
\text { Thy }
$$

Lisardo (regarding his band in horror). Oueen: Nay, it is clean!

Queen: Nay, it is clean!
Lisardo: $\quad$ Yet here's a spot.

Lisardo:

Queen:

Nay, nay, not mad! Come, let them pay their vows,

'Tis well. And set the crown upon my brow,

For e'en to dizzier heights I do aspire.

But-I will hide this hand for it is stain'd,

And some may mark a drop of blood is there. ${ }^{1}$

Only less noticeable are the unseen dagger spoken of by the Evil Genius in the same scene; the reproaches which the Queen directs to Lisardo after the murder; the royal feast which follows Lisardo's accession ; the appearance of the witch to him after his crime; and the passing across the stage of the spectre of the murdered King. The last is distinctly suggestive of the appearance of " blood-bolter'd Banquo" :-

(The ghost of the King in mantle and crown rises swiftly, sbowing the breast wounded and issuing blood).

King: See, traitor, I protected thee, and thou Didst pay me thus ?

$$
\text { (Vanishes) }
$$

Lisardo (terror-stricken) : Ah, what-ah, what is this Mine eyes have seen ? What vision horrible ? And how abominable do I seem

Now that I view and contemplate my deed ! 2
I. Desengaño, II, ii.
2. Desengaño, IV, ii.

The history of Shakespeare's vogue in Spain in the nineteenth century has yet to be written; but if there are many undiscovered tributes to his greatness as striking as that which Rivas quietly paid in this drama, it may in the end assume proportions at present not suspected. 


\section{CHAPTER VII}

RELIGION

Apart from the vexed question of Rivas' relations with Romanticism-which is complicated by the difficulty of exactly defining that movementthere are few contradictions or inconsistencies between the different periods of his work. The principal aspects of his genius changed very little. A love for picturesqueness, for colour and light, for versified narrative, for re-creating Andalucian scenes-these qualities are as unmistakeable at seventeen as at seventy. Like most of his Spanish contemporaries Rivas cared little for the ideas that lay beneath poetry or drama. $\mathrm{He}$ made no claim to be a thinker. When he imitates Shakespeare, it is Shakespeare's dramatic effects that he reproduces-not Shakespeare's thought. Little or nothing lies beneath the surface of his charming pictures, and hence there is little or nothing in them that challenges discussion.

An exception may be found in his religious ideas and sentiments, for not only is his preoccupation with these an outstanding feature of his writings but it presents some interesting problems to the student. In private life the Duke was, so far as available testimony determines, an orthodox and conforming Catholic. His literary attitude to religion, however, varied considerably and is by no means easy to estimate. We can see forces at work in his early life which might well have predisposed him to unorthodoxy. His interest in the Moors and sympathy with their great heroes has already been described. His association with foreigners and enlightened thinkers during the wars may well have reacted upon his religious views, while the bitter experiences of the succeeding years, together with possible associations in Malta and elsewhere, very probably played their part. Thus, with so many disturbing influences, it is not surprising if the religious elements in Rivas' works form something of a tangled web.

The first point which stands out clearly is Rivas' preoccupation from the time of his early youth with the problems of destiny and free-will. As a boy of seventeen we find him adopting a fatalistic attitude towards the war: how could his country triumph over the "fierce destiny" which clouded its fair days? It is the same "fierce destiny" which eleven years later is made responsible for keeping him from his "Olimpia," and which again in 1829 is separating him from his family. In Florinda we find, as it were, a preliminary sketch of Don Alvaro in its insistence upon the "force of destiny." Numerous references to fate would be expected in a romance concerned with the Mohammedan era in Spain, but hardly that Destiny, in her own form, or scarcely concealed under an appearance of Christianity, should preside over the whole story. Yet such is the position. Misfortunes which occur are the work of "fearful destiny" or the "rigour of the stars." One character after another is described as being swayed or led by the influence of the stars, and the phrase used is often a strong one : " arrastrado por su estrella." The reader is reminded now and again that he too is not a free agent, and this in passages by no means artistically relevant. The author's own 
reflections, too, take this standpoint. When a man loses hope, he says, let him go down to the grave, for Destiny is calling him-and at the beginning of Canto III he even makes a digression to speak in this way of his own unhappy lot :-

$$
\begin{aligned}
& \text { ¿Mísero yo, que en ilusión perdido, } \\
& \text { Pude un momento la crueldad del hado } \\
& \text { Dar y mi suerte bárbara al olvido ! } \\
& \text { ¡ Ay! El tiempo dichoso aun no es llegado. } \\
& \text { Una tremenda voz hiere mi oído, } \\
& \text { Voz de infortunio, de despecho y muerte; } \\
& \text { ¡Oh cuán terrible es la sañuda suerte ! }
\end{aligned}
$$

It was no new inspiration, then, which led Rivas to embody in the story of Don Alvaro the central idea of a fierce and implacable Fate, against which the hero should strive in vain. As we have seen, the Fate in question succeeds in making a great impression upon the stage, but its exact nature and motives hardly bear the searching light of analysis. Can a Fate really be a success when half the critics declare it to be non-existent or mistake it for Providence?

Yet the intention, at least, of Don Alvaro is fatalistic, and the play is so full of pagan ideas and sentiments that quotation is unnecessary. It is more instructive to examine the setting in which these ideas have been placed and to debate why Rivas should have presented his Fate in such curiously orthodox surroundings. Probably it is the religious atmosphere of many of the scenes of Don Alvaro which has misled those who try to make the play a "moral" one, since they affirm, for the most part with considerable vehemence, that the Duke was incapable of leaving the orthodox religious position. When one comes to look carefully into the play, one realises that it is

I. II, 4 I6. indeed a curious mixture of Christianity and paganism. The Marquis of Calatrava and his family are orthodox, even devout, Catholics. Leonor continually invokes the Virgin, and observes in detail the practices of the Faith. Alfonso apparently takes after her, though the Marquis shows none of Alfonso's anxiety for the welfare of his soul, nor does Carlos use religious language. But far more important than these characters is the hero, who, in spite of all his talk of fate, and his terrible end, is a religious conformer, and accepts religious standards. As soon as he speaks, conventional phrases of piety spring to his lips. ${ }^{1}$ The elopement is to be followed immediately by a marriage in church, in all due form and order ; the priest is even now waiting and the church is in readiness. So the lover announces in respectable riming couplets, to his lady :-

$$
\begin{aligned}
& \text { En San Juan de Alfarache, preparado } \\
& \text { Todo, con gran secreto, lo he dejado. } \\
& \text { El sacerdote en el altar espera ; } \\
& \text { Dios nos bendecirá desde su esfera. }{ }^{2}
\end{aligned}
$$

After the initial tragedy, Don Allvaro is for some time "off," and when he reappears he has more of the pagan than the Christian, but after a long period, during which the religious problem hardly arises from the action, the hero's propensities begin to re-assert themselves. "Just God!" is his cry on hearing that Doña Leonor still lives. ${ }^{3}$ " Beg forgiveness of Heaven" is his parting word to Don Carlos. ${ }^{4}$ In the long apostrophe to Leonor he uses once more that phrase " the throne of the

I. E.g., ¿ Te complaces

En levantarme al trono del Eterno ? . . .

2. VI, 256 .

3. VI, 344 . 4. VI, 346 
Eternal" which came once so glibly into his declarations of constancy and has no doubt been often since on his lips. ${ }^{1}$ As the hour draws near when he believes that he is to be executed for homicide he remembers that he must meet his Maker. ${ }^{2}$ When death comes, it comes as the gift of God: he will meet it with Christian resignation. ${ }^{3}$ And it is natural enough that on his escape he fulfils in spirit that vow naturally made by a good Catholic - a vow "to renounce the world and to finish my days in a desert."4 Leonor has already, and more literally, acted upon a similar resolution. As to the last act, it is enough to say that if Don Allvaro, by his renunciation of eternal life, raises himself dramatically to the greatest heights, he proves, first by embracing the religious life, and afterwards by both implicit and explicit confession, his eternal belief in that which under provocation he throws away.

The stagecraft of the play has done even more than the action and characterisation to emphasise its religious nature. Among the minor personages who impress themselves strongly on the spectator are the genial Canon of the opening scenes, the Padre Guardián and the Hermano Melitón, representing respectively the grave and the humorous features of monastic life. The characteristic details of a country pilgrimage are introduced with effect, and ecclesiastical small talk is common. More important still is the purely scenic influence of convent interiors, cells, oratories, crosses, breviaries, the organ heard

$$
\begin{aligned}
\text { I. VI, 360. “. . . En donde el trono del Eterno brilla." } \\
\text { 2. VI, 362. " } 3 \text {. Ibid. } \\
\text { 4. VI, 365: "Yo os hago, eterno Dios, voto profundo } \\
\text { De renunciar al mundo } \\
\text { Y de acabar mi vida en un desierto." }
\end{aligned}
$$

playing "within," the choir chanting matins, and the like. The last act and the final tableau set, as it were, the religious seal on Don Alvaro. The pagan interpretation of the play has been once more re-asserting itself throughout the quarrel and fight and the furious actions of the hero in the concluding scene. But the chorus of friars invoking mercy from heaven as their apostate brother flings himself down to destruction rings in one's ears and remains with one as the final and abiding impression.

The problem of Don Alvaro, then, which in itself merits and requires a separate volume, is not merely that of the nature of Rivas' sino, but involves the reconciliation of the pagan and Christian elements in the play, both of which are greatly in evidence. Here we can but hazard a solution. It is that Rivas, neglectful or unmindful of his critics, and with his eye on the stage alone, set out consciously to combine what was most attractive to him in pagan and Christian ideals, to present the theme of fate, which had for long attracted him, in an atmosphere of popular devotion. Or, alternatively, it may be that, intending at first to make one of the two ideals (the pagan, in all probability) predominate, he found the other, in the end, too strong for him. Some such view must explain the contradictions in the design of Don Alvaro, for, though Catholicism and fatalism cannot go hand in hand, nor the Romantic hero play the villain in the moral apologue, an author who has temperamental affinities with both the one and the other cannot successfully confine himself to either.

Once only, after Don Alvaro, did its author revert to the theme of destiny and make it the subject of a complete work. This was in the play 


\section{II8 RIVAS AND ROMANTICISM IN SPAIN}

El Desengaño en un Sueño, where the Duke freed himself entirely from those shackles of religious convention which obstructed the design of the earlier drama. From the opening lines of the play, in which Lisardo calls upon the "impious destiny that imprisonest my ardent soul," that goddess reigns supreme. When Lisardo sleeps, his father invokes the "powers of Heaven and Hell that guide a wretched mortal's destinies." Just as before his dream the youth had thought of himself as " born under an evil star," so, after usurping the throne, he tells his Queen that it is "Destiny" which has put its burden upon his shoulders, and the Queen reciprocates the sentiment, speaking of the height to which his "star" has raised him. He wonders why his Destiny should not have placed him in a royal cradle, debates whether man can be the sport of some inscrutable power, and exclaims that " man's fearful destiny" must be to commit crime. When he has escaped from the royal feast, he seeks to appease the "rigour of his Destiny," and finally cries, in what may be his last moment: "Let us fly-if indeed my Destiny has left me in mercy one avenue of escape," adding, when there seems to be none, "Come then, death, and let my terrible lot be fulfilled." At the end of the dream Marcolán conjures the spirits by the same invocation as he had used before, though one is left debating what exactly "Destiny" can be, since the magician claims himself to control the spirits of good and evil, who elsewhere in the play are represented as shaping the "destinies" of wretched mortals!

Passing now from lyric and drama to Rivas' domain par excellence of narrative poetry we meet the same problem of antagonism between con-

\section{RELIGION}

flicting religious ideals. In the Moro Expósito, where the task of doing justice to two civilizations presented itself, such antagonism was to be expected. But it was also to be expected that the contrast would show in no uncertain way the superiority of the Christian civilization over the Mohammedan. This it can hardly be said to do. It is true that the later cantos, and in particular the final situation, are a glorification of the Christian ideal; but unfortunately they are already prejudiced by the unworthy presentation of that ideal and the glorification of its antithesis in the earlier and very much larger part of the poem.

Of Mohammedan theology, as conceived by Rivas, a great deal might be said. It is based almost wholly upon Destiny - " cruel," " blind," " inexorable," "mysterious," " unfathomable"a force envisaged by Mudarra, not as part of God's design, but as altogether independent of Him. This Destiny is made responsible for all the evils of life : for Mudarra's loss of his mother no less than for the " accident" which results in Giafar's death. The strange letter which Mudarra writes to Kerima after he has killed her father, sounding so callous to modern and Christian ears, is the natural expression of the crude Mohammedan theology of an adolescent :-

$$
\begin{aligned}
& \text { Kerima: yo a tu padre be dado muerte; } \\
& \text { Mas no fui yo, fué sólo su destino; } \\
& \text { Le beri sin conocerle, defendiendo } \\
& \text { La vida, que arrancarme aleve quiso. } \\
& \text { Perdóname, mi bien: el justo cielo } \\
& \text { Dirigió el duro golpe. . . I Mas qué digo ? } \\
& \text { Para matarle sólo fui engendrado: } \\
& \text { Soy del noble señor de Lara bijo . . . }
\end{aligned}
$$

The theology of Zaide the sage lifts us higher.
I. III, 200 . 


\section{I20 RIVAS AND ROMANTICISM IN SPAIN}

Where the boy sees only the stars the old man sees a conscious Force which uses them as instruments of His sovereign will. Yet this is not to deny the reality of their influence nor the justice of their decrees. No mortal can stay their course, nor alter their immutable judgments. And this is well, declares Zaide, for in the end the rulings of fate will be found to be righteous, the workings of a Power whose laws are justice itself.

When we travel northwards and enter the realms of Christian theology, it is a little surprising to hear the faithful Nuño at first using the language of Mohammedan fatalism, though the next moment finds him recalling to Lara, as well he may, that they are Christians, and consoling him with the certain hope of everlasting life. Both Nuño and Rui-Velázquez freely intermingle Christian and pagan ideas, though the former predominate. This may or may not be intentional.

In order that the Christian tone might colour the later cantos, Lara had to be presented as a devout and penitent Christian. Resignation to the will of God is ever uppermost in his mind, and for a time he even refuses to allow Mudarra to consider avenging him :-

No quiero, no, venganzas, hijo mío,

Funestas siempre a quien tras de ellas corre.

Perdonados estan mis enemigos:

Perdonados están. Dios me perdone
Como yo les perdono. ${ }^{1}$

The father's first thought is for his son's religion. Have his worst fears foundation $?^{2}$ Born in a land of error, can the boy have failed to learn of the

I. III, 300.
2. III, 299. sacred faith of his fathers ? Then he realises that the Almighty may have sent this long-lost son to avenge him, and hails him as "minister of the wrath of the Eternal," a view which Zaide confirms. ${ }^{1}$ But the Christian spirit soon re-asserts itself; no further word of vengeance falls from Lara's lips; instead, he begs the beholders to thank God on his behalf for having sent him an heir to his house and name, and to pray that he may never be forsaken by Him. ${ }^{2}$

One of the few strong contrasts between the Mohammedan and the Christian points of view is in the attitude of Zaide and that of Lara towards the latter's irregular union with Mudarra's mother. The Mohammedan sees in their child only the instrument of God's vengeance ${ }^{3}$; Lara is conscious only of his sin, and cries Mea culpa! All that he has suffered is to him the punishment of an outraged Deity for that $\sin ^{4}$; and the double crime of having sinned with an unbeliever, however virtuous, whom God may have sent to him to be evangelised, ${ }^{5}$ has brought him a double punishment. This contrast will be found, as it were, to be crystallised in the scene of the meeting of Lara and his son. ${ }^{6}$

These, then, are the Mohammedan and Christian points of view as Rivas presents them. What of the passages in which he is speaking for himself?

It must be confessed that his theology as expressed in the Moro Expósito is nearer to Mohammedanism than to the Catholic faith. He seems to have placed himself between the disputants, and to have echoed the sentiments,

I. III, 302. 2. III, 303. 3. III, 300 .

4. III, 23I. 5. III, 280. 6. Canto VII (III, 297 ff.). 
now of one, now of the other, or, more often, to have adopted as much as was common to both.

There is an almighty and inexorable Deity, whose finger points the course of the sun, ${ }^{1}$ whose designs are impenetrable, whose punishments are as awful as His justice is sure. ${ }^{2} \mathrm{He}$ is always the God of the Psalmist :-

He that sitteth in the Heavens shall laugh :

The Lord shall have derision over them.

Yet $\mathrm{He}$ is on the side of good against evil. His are the interventions of what we call "chance"-the death of Giafar, the incident which prevents Mudarra from being poisoned, the imprecations of Elvida and their sequel. $\mathrm{He}$ metes out punishment to Lara with dreadful severity-some may say with more severity than justice-but Lara has after all sinned greatly, and he is made throughout the story to recognise the justice of his sufferings. In the end, it must be remembered, Lara regains his son, and his name is handed down to successive generations, while Rui-Velázquez as well as Giafar comes to a fearful end. And before that time Rui-Velázquez has lost both his wife and his son, is hated by all and tormented by his conscience. It will be noted, in passing, that Rivas' Deity does not condone a nominal Christianity: the "Christian" Rui-Velázquez and the heathen Giafar are treated with equal justice according to their deeds and the lights which they had to guide them.

This is not, of course, an argument against the Christian character of the author's positionrather the reverse, for by no known standard of official Christianity can Rui-Velázquez be enrolled on the side of the angels. But there is no need

$$
\text { I. III, } 23.2 \text { III, } 182, \mathrm{cf} \text {. III, } 416,510 .
$$

to labour the clearly demonstrated tendency of Rivas' theology. So nearly does he approach the Moslem standpoint that once (when writing in his own person) he refers to his Deity as "el Destino. 1" Later in the poem, it is true, he adapts himself noticeably to his Christian environment, describing the baptismal and nuptial ceremonies with some care though with no great enthusiasm. But it is noteworthy that when he relates the refusal of Kerima to give her hand to Mudarra (a situation full of possibilities) the author merely professes his inability to say more, and concludes with the remark that Mudarra, strengthened by " celestial grace" or temporal consolations, was sufficiently resigned to his lot to marry another and so to continue his father's name and lineage. A professedly and emphatically Catholic writer might have been expected at least to show some satisfaction at Kerima's decision.

A strange feature of the Moro Expósito, which throws into relief the author's failure to write from the distinctively Christian standpoint, is his bold and frequent satire of the clergy. Quite out of place in a Christian romance contrasting the two civilizations of tenth-century Spain, this trait is also so far removed from the general tone of Rivas' writing's that one is somewhat at a loss to explain it. Only one churchman-the lowly hermit Ildovaldo-escapes the author's satire. The "archpriest" - in constant request during the latter part of the romance-is the principal

I. III, 210 : $\quad \ldots$ Un amor funesto, que el Destino Inexorable contrarió.

This Destiny is not, of course, to be confused with the "destino inexorable y duro," subordinated to the will of Heaven, which Rivas speaks of in connection with his own exile, e.g., III, 266 , 11. I $5 \mathrm{ff}$. 
object of Rivas' irony. $\mathrm{He}$ is represented as a dull and pompous orator, given to lengthy sermons intercalated with long quotations from Holy Scripture, but withal shrewd and worldly wise enough upon occasion. We all know Rivas' arcipreste, for this picture is repeated with variations until we are weary of it :-

Discreto, para darle el Arcipreste
El tiempo indispensable, concluídas

De Gustios y del pueblo las plegarias,

Con gran solemnidad y melodía

Cantó un largo $\tau_{e}$ Deum, y un discurso

O plática muy larga y muy prolija

Hizo a sus feligreses, que ignorantes

Bostezaron tal vez, aunque de citas

De la santa Escritura estaba llena,

Que era gran sabidor. Después aplica

A los ojos inútiles del viejo

Salmos, $y$ bendiciones, y reliquias,

$\mathrm{Y}$ da con ellas paz a los hidalgos ;

Y por ganar más tiempo, a una capilla

Conduce a Gustios y a otros personajes,

$\mathrm{Y}$ alli difusamente traza y pinta

Los reparos y nuevos ornamentos

De que la iglesia aquella necesita ;

Entablando sagaz de estas materias

Entablando sagaz de estas materi
Una conversación entretenida ${ }^{1}$.

Again, it will be remembered that RuiVelázquez, after visiting the hermit Ildovaldo without success, repairs to a majestic prelate, who grants him his desire-upon conditions. Satire is perhaps implicit in the situation, and Rivas brings it out to the full. The dress of this new Prior of Jorvaulx, the small army of retainers which surrounds him, and the author's comments upon their varied qualifications-all this leads up to a description of the prelate's person in which the malice is unmistakeable :-

I. III, 243 .
Muestra su persona

Sexagenaria edad, pero robusta,

Regular talla, obesidad notoria,

Gravedad afectada, paso tardo,

Fuerte respiración, mas trabajosa.

Son sus ojos alegres y vivaces,

Brota salud su faz fresca y redonda ;

Y sus anchas mejillas rubicundas

Y su nariz, hacia la punta roja,

su nariz, hacia la punta roja,
Que sabrosos manjares, suculentos

$\mathrm{Y}$ abundantes, su pasto son, denotan;

Y abundantes, su pasto son, denotan ;

Vinos añejos de poder y aroma. ${ }^{1}$

The scene which follows is ironical from beginning to end. Never was penitent's confession so described in anything but a burlesque! Then follow caricatures of two clerical satellites: the tall, thin and sharp-featured padre receptor, and contrasted with him the padre despensero, short-necked, snub-nosed, with " round and bulky paunch" and rubicund countenance. And this is the tone of the satire throughout. Even at the baptismal ceremony a score of monks "with albs ungirt, big-bellied and bull-necked" are introduced into an otherwise idealistic scene.

At one point Rivas feels that he has gone so far as to make some excuse essential, and he adds in a note that he is " attempting only to depict the customs of the tenth century, presenting the monks as they generally were in those ages of darkness and confusion., ${ }_{2}$ But one would rather suspect that his satirical passages had some raison d'être in a private enmity, or are due to one of those whimsical follies which sometimes attack men of genius for no apparent reason, and which they will often defend as warmly as their considered principles and beliefs.

I. III, 458-9.

2. III, $473 \mathrm{ff}$. (Author's note 35 ). 


\section{I26 RIVAS AND ROMANTICISM IN SPAIN}

With the Romances Historicos and the Leyendas a complete change comes over Rivas' literary presentation of religious ideas and sentiments. It has just been remarked how little in the Moro Expósito can be called distinctively Catholic. Scarcely an allusion, for example, can be found to the Second and Third Persons of the Trinity, or, with the exception of Baptism, to the Church's " high mysteries"; while only once or twice are there references, and these in character, to the Mother of God. ${ }^{1}$ In Don Alvaro the environment is religious, and there is little in the play which could give offence to a churchman-provided always that he possessed a sense of humour; yet the impression it leaves, as has been seen, is a mixed one. In the last two collections all is different. The patriotism of the Romances Históricos is bound up with religion. Only occasional and meaningless phrases indicative of fatalism remain - those which anyone may use in conversation. The reality is gone. Man is no longer the sport of fate, but "the instrument of wise Omnipotence." " None can penetrate His designs." "Sacred and inscrutable are the judgments of the Lord."2

Coming to details, one feels now that the author believes in what he writes of. In the whole of the Moro Expósito there is nothing to show that the author's attitude to the principal mystery of the Catholic Church-the Holy

I. But see III, $234,11.25-30 ; 259$, 11. 9-I2 ; $281,1.30$; 282,1. I ; 446, 11. 20-5; 447, 11. I6-I 8; 45 I, 11. 25-30; 454, 11. 9-16, 464 , 11. 9-16; 469, Il. 4-12. These are the only examples of references to distinctively Catholic doctrine and ritual in the book, apart from one or two phrases such as " nuestros altos misterios," which are conventional and vague.

2. IV, III, cf. pp. $4,78,145,264,409$.
Eucharist-was other than that of a Protestant. Now he can speak with evident sincerity of the "Sacrifice" of the Altar, the "bread of eternal life," the "enthusiasm and living faith" of the communicant. He describes the Church's last offices, the Divine consolations and means of grace provided for the faithful who desire them, the "magnificent temples" which exalt the faith of Christendom, and the infinitely more glorious throne of the Almighty surrounded by archangels whom $\mathrm{He}$ sends forth to do His bidding. ${ }^{1}$

Still more real is the religious element in the Leyendas : religion and patriotism, indeed, are their primary inspiration, and the impression which they make on many is that of a religious trilogy. The miraculous parts of the story of the Lily are in harmony with mediaeval piety: the dispensation of Almighty God by which the false Rodrigo, condemned to eternal torment, is allowed for a time to retain a part of his life; the doe leading the penitent to the miraculous chapel of Our Lady; and lastly the lily which symbolises the completion of Nuño's penitence. For, though he blasphemes God for a space in his ignorant fury, Nuño Garcerán soon repents, confesses, makes a pilgrimage to Santiago de Compostela, and spends the remainder of his life in penitence, striving against Satanic visions and sustained by his guardian angel, till he attains Divine forgiveness. The narrative of "Maldonado" has at least a religious background, and the shrine at Montserrat is described with a sympathy and at a length which give it more importance than its place in the story warrants. "El Aniversario" closes with the most typically

I. IV, $162,274,284,251,260,4^{10}$. 
Catholic episode to be found in any of Rivas' plays or poems-that of the ghostly congregation at Mass in the Cathedral of Badajoz.

The general impression of the Leyendas is strongly reinforced by a more detailed examination. Scarcely a reference to "Destiny" remains now. Where a man is "fated" or " doomed" it is always " by heaven " or "by Providence."1 The pagan significance of the word destino has disappeared with the capital letter. Allusions to the practices of the Church abound, especially to the sacraments of baptism, the Mass and penance. But the most striking characteristic of the religious allusions in these poems is the frequency of the references to Our Lady, which it would require much space to set out in full. Scarcely mentioned in Rivas' earlier poems, she receives full reparation now. Again and again she is spoken of as the "Mother of God" or the "Mother of the Word"; frequently, too, she is given her other titles-such as "Star of the Sea," "Queen of the Angels" 2 - or she is represented as appearing in her local habitations; above all, as might be expected from the date at which the collection was published, she is Mary the Immaculate. ${ }^{3}$ It is principally in connection with Our Lady, too, that the reader is continually reminded of the ministering offices of the angels, the prayers of the saints, and the hymns of the cherubim, which, in one place, repeat the salve of the penitent sinner, and with it rise to the throne of God.

Everywhere in the Leyendas the poet takes the Christian point of view, never turning, with the

I. E.g., $V, 307,338,340 . \quad$ 2. E.g., V. $306,326$.

3. "La Virgen sin mancha," etc. V, 21 $7,309$. suddenness of drama, as in the Moro Expósito, to write from another standpoint. As if to atone for the exaltation of Mohammedan rule in that legend, Rivas writes now of the struggle to reconquer Spain with all the fervour at his command. It was an attempt made

Para lanzar el torpe mahometismo

Que aun del reino asombraba los confines,

Y plantar de Granada en el turbante

The Catholic Monarchs are "suns still shining in eternal glory" whose " high mission" was given them by God :-

... . la grande Isabel y (el) gran Fernando

La garganta pisando

Del islamismo con tan firme planta,

Que jamás volvería

El brillo a obscurecer de la fe santa,

Ni a profanar la hermosa Andalucía.

Granada, "once stained with the mire of lascivious ceremonies and rites by Heaven accursed" has now "the Catholic faith in its bosom," and instead of "Mohammedan blasphemies" hears "the blessed words of the holy Gospel" in what were once its mosques. ${ }^{3}$ Unbelief is poetically represented as the "darkness of the dense infernal fogs in which the rebel Archangel enfolded the most fertile of all regions of the world." And the triumph of Catholicism in Mexico becomes the crushing of the serpent's head by the might of the Cross. ${ }^{5}$

After many deviations and changes, Rivas is at last, emphatically, passionately and wholeheartedly, on the side of the angels.

THE END

\begin{tabular}{ll}
\hline I. V, 214. & 2. V, 229. \\
4. V, 259. & 5. V, V, 26I, cf. 268.
\end{tabular}




\section{SELECT BIBLIOGRAPHY}

OF WORKS RELATING TO THE DUQUE DE RIVAS.

Collected Editions of Rivas' Works.

The latest so-called "complete" edition is that in the "Coleccion de Escritores Castellanos" series, in seven volumes (Madrid, 1894-1904). Its most notable omission is El Desengano en un Sucio, which can be read in the earlier editions of $1854^{-5}$ (Madrid, 5 vol.) and $1884-5$ (Barcelona, Montaner y Simón, $z$ vol.)

Editions of Single Works (Short Titles).

1814 Poesías de Don Angel de Saavedra, Cádiz, I8I4. (Rare. To be found in certain libraries in Sevilla and Códiz.)

1816 Aliatar. (Rare. The only copy known to the writer is in the Biblioteca Municipal, Madrid.)

1820-I Poesías. . Segunda edición corregida y aumentada, Madrid, $1820-1,2$ vol. (In the British Museum and many large Spanish libraries.)

1834 El Moro Expósito, o Córdoba y Burgos en el siglo décimo, Paris, I834, 2 vol. (Re-issued, 1901, in the Biblioteca Paris, I834, 2 vol. (Re-

1835 Don Alvaro, o la Fuerza del Sino, Madrid, 1835 (Re-issued; Madrid, 1857, 1882, 1889, and in an edition without date.)

I840 Tanto vales cuanto tienes, Madrid, I840.

I84I Romances bistóricos, Paris, 184I. (Another edition, Madrid, I84r. Edited with introduction and notes in the Clasicos Castellanos series, 1912, 2 vol.)

I84I La Morisca de Alajuar, Madrid, I84I.

I84I Solaces de un prisionero, o Tres Noches de Madrid, Madrid, I841.

1842 El Crisol de la Lealtad, Madrid, 1842 .

I844 El Parador de Bailén, Madrid, I844.

I844 El Desengaño en un Sueño, Madrid, I844.

I844 (In Revista de España y del Extranjero, Vol IX, pp. I $45-167,333-349)$ two prose sketches, entitled
"Viaje a las ruinas de Peste" and "Viaje al Vesuvio."

1848 Sublevación de Nápoles capitaneada por Masanielo. . Estudio histórico, Madrid, I848, 2 vol. (Re-issued, Madrid, Victor Saiz, I881.)

I85I El Crepuisculo de la Tarde, versos de Don Angel Saavedra, Duque de Rivas, Madrid, I85I. 
I32 RIVAS AND ROMANTICISM IN SPAIN

Principal Critical Articles and Studies.

1835 L. A. Cueto in El Artista, Vol. III, pp. 106-8, I10-4 (a critique of Don Alvaro).

184I Enrique Gil y Carrasco in El Pensamiento, reprinted in his Obras en prosa, Vol. II, pp. 146-165, Madrid, 1883. (A notable review of the Romances bistóricos.)

1846 Antonio Ferrer del Río, in Galeria de la literatura española.

I846 Charles de Mazade, "Poètes modernes de l'Espagne: le Duc de Rivas," in the Revue des Deux Mondes, I 846 , pp. $321-354$.

I854 Juan Valera, in Florilegio de poesias castellanas del siglo XIX, Vol. I, pp. 88-105, Madrid, I854.

1866 José Amador de los Ríos, "Discurso en elogio del Duque de Rivas." In Discursos leídos en las recepciones y actos públicos celebrados por la Academia de Nobles Artes de San Fernando, Madrid, 1866.

1867 Nicomedes Pastor Diaz, in Obras de D. . . . Madrid, I867 Vol III, Pp. I99-279: "Don Angel de 1867, Vol. In, pp. 199-279: "Dof "Angel de by an appendix, pp. 279-28 by an appendix, Pp. $279-284$, covering the years introditer, to Vol. I of the in 84 edition by the sive witer, to Vol. 1894 edit

1870 L. A. Cueto, "Discurso Necrológico literario en elogio del Duque de Rivas." In Memorias de la Academia Española, Vol. II, pp. 498-560. Madrid, 1870

884 Manuel Cañete. In Escritores españoles e bispano. americanos. Madrid, I884. (An important study).

1889 Juan Valera. In El Ateneo, Vol. I, I888-9: “Estudio biográfico." Also in Critica literaria, 1887-9 (Vol. 27 of Valera's collected works), pp. 71-196. (Valera was attached as a youth to Rivas staft at Naples. His criticism is strongly subjective, bu always worth reading.)

1899 E. Funes, "Don Álvaro . . . Estudio crítico," reprinted from the Diario de Cadiz.

1904 Enrique Piñeyro, El Romanticismo en España, 1904 Pp. 51-93.

I916 Azorin, Rivas y Larra-razón social del romanticismo en España, Madrid, I916, pp. 13-135, 281-7. 
Biblioteca de

RUSSELL P. SEBOLD 